NOAA Technical Report NMFPcumentis 430

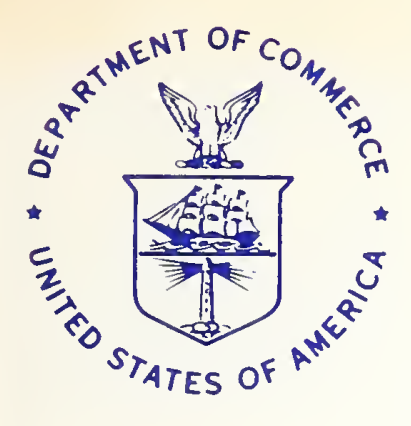

\title{
Guide to Identification of Some Sculpin (Cottidae) Larvae from Marine and Brackish Waters off Oregon and Adjacent Areas in The Northeast Pacific
}

Sally L. Richardson and Betsy B. Washington

January 1980

U.S. DEPARTMENT OF COMMERCE

National Oceanic and Atmospheric Administration National Marine Fisheries Service 


\title{
NOAA TECHNICAL REPORTS
}

\section{National Marine Fisheries Service, Circulars}

\begin{abstract}
The major responsibilities of the National Marine Fisheries Service (NMFS) are to monitor and assess the abundance and gengraphic distribution of fishery resources, to understand and predict fluciuations in the quantity and distribution of these resources, and to establish levels for optimum use of the resources. NMFS is also charged with the development and implementation of policies for managing national fishing grounds, development and enforcement of domestic fisheries regulations, surveillance of foreign fishing off United States coastal waters, and the development and enforcement of international fishery agreements and policies. NMFS also assists the fishing industry through marketing service and economic analysis programs, and mortgage insurance and vessel construction subsidies. It collects, analyzes, and publishes statistics on various phases of the industry.

The NOAA Technical Report NMFS Circular series continues a series that has been in existence since 1941. The Circulars are technical publications of general interest intended to aid conservation and management. Publications that review in considerable detail and at a high technical level certain broad areas of research appear in this series. Technical papers originating in economics studies and from management investigations appear in the Circular series.

NOAA Technical Report NMFS Circulars are available free in limited numbers to governmental agencies, both Federal and State. They are also available in exchange for other scientific and technical publications in the marine sciences. Individual copies may be obtained (unless otherwise noted) from D822, User Services Branch, Environmental Science Information Center, NOAA, Rockville, MD 20852. Recent Circulars are:
\end{abstract}

\begin{abstract}
396. Whales, dolphins, and porpoises of the western North Atlantic. A guide to their identification. By Stephen Leatherwood, David K. Caldwell, and Howard E. Winn. August 1976, iv + 176 p., 168 figs., 1 table, 14 app. figs. For sale by the Superintendent of Documents, U.S. Government Printing Office, Washington, DC 20402; Stock No. 003-02000119-0.
\end{abstract}

397. Marine flora and fauna of the nurtheastern United States. Cnidaria: Scyphozoa. By Ronald J. Larson. August 1976, iii + 18 p., 28 figs. For sale by the Superintendent of Documents, U.S. Government Printing Office, Washington, DC 20402; No. 003-01700387 .

398. Marine flora and fauna of the nort.،eastern United States. Higher fungi: Ascomycetes, Deuteromycetes, and Basidiomycetes. By A. R. Cavaliere. March 1977, iii +49 p., 24 figs. For sale by the Superintendent of Documents, U.S. Government Printing Office, Washington, DC 20402; Stock No. 003-020-00126-2.

399. Marine flora and fauna of the northeastern United States. Copepoda: Harpacticoida. By Bruce C. Coull. March 1977, iii + 48 p., 100 figs. For sale by the Superintendent of Documents, U.S. Government Printing Office, Washington, DC 20402; Stock No. 003-020-00125 4.

400. Fishery publication index, 1965-74. By Mary Ellen Engett and Lee C. Thorson. March 1977, iii +220 p. For sale by the Superintendent of Documents, U.S. Government Printing Office, Washington, DC 20402; Stock No. 003-020-00127-1.

401. Fisheries and fishery resources of New York Bight. By J. L. McHugh. March 1977, v + 50 p., 43 figs., 49 tables. For sale by the Superintendent of Documents, U.S. Government Printing Office, Washington, DC 20402; Stock No. 003-020-00129-7.

402. Guide to the identification of scorpionfish larvae (Family Scorpaenidae) in the eastern Pacific with comparative notes on species of Sebastes and Helicolenus from other oceans. By H. Geoffrey Moser, Elbert H. Ahlstrom, and Elaine M. Sandknop. April 1977, v + 71 ค., 40 figs., 38 tables. For sale by the Superintendent of Documents, U.S. Gov. ernment Printing Office, Washington, DC 20402; Stock No. 003-02000128-9.

403. Marine flora and fauna of the northeastern United States. Sipuncula. By Edward B. Cutler. July 1977, iii +7 p., 6 figs. For sale by the Superintendent of Docum^nts, U.S. Government Printing Gffice, Washington, DC 20402; Stock No. 003-012-00404-0.

404. Revision of the sea basses of the genus Diplectrum (Pisces: Serranidae). By Stephen A. Bortone. September 1977, v +49 p., 15 figs., 9 tables.

405. Marine flora and fauna of the northeastern United States. Echinodermata: Holothuroidea. By David L. Pawson. September 1977, iii + 15 p., 3 figs. For sale by the Superintendent of Documents, U.S. Gov- ernment Printing Office, Washington, DC 20402; Stock No. 003-0170040-4.

406. Marine flora and fauna of the northeastern United States. Copepoda: Lernaeopodidae and Sphyriidae. By Ju-Shey Ho. December 1977, iii + 14 p., 16 figs. For sale by the Superintendent of Documents, U.S. Government Printing Office, Washington, DC 20402; Stock No, 003-017-00412-1.

407. Distribution of decapod Crustacea off northeastern United States based on specinens at the Northeast Fisheries Center, Woods Hole, Massachusetts. By Austin B. Williams and Roland L. Wigley. December 1977, iii +44 p., 2 figs., 1 table, 57 charts.

408. Collection of tuna baitfish papers. (20 papers.) By Richard S. Shomura (editor). December 1977, iii $+167 \mathrm{p}$.

409. Marine flora and fauna of the northeastern United States. Ccpepoda: Cyclopoids parasitic on fishes. By Ju-Shey Ho. February 1978, iii + 12 p., 17 figs.

410. The 1976 Ceratium tripos bloom in the New York Bight: Causes and consequences. By Thomas C. Malone. May 1978, iv + 14 p., 17 figs., 1 table.

411. Systematics and biology of the tilefishes (Perciformes: Branchiostegidae and Malacanthidae), wich descriptions of two new species. By James K. Dooley. April 1978, v +78 p., $4^{4}$ figs., 26 tables.

412. Synopsis of biological data on the red porgy, Pagrus pagrus (Linnaeus). By Charles S. Manooch III and William W. Hassler. May 1978, iii + 19 p., 12 figs., 7 tables. For sale by the Superintendent of Documents, U.S. Government Printing Office, Washington, DC 20402; Stock No. 003-017-00418-0.

413. Marine flora and fauna of the northeastern United States. Crustacea: Branchiura. By Roger F. Cressey. May 1978, iii + 10 p., 15 figs. For sale by the Superintendent of Documents, U.S. Government Printing Office, Washington, DC 20402; Stock No. 003-017-004_ 3-8.

414. Synopsis of biological data for the winter flounder. Pseudopleuronectes americanus (Walbaun:) By Grace Klein-MacPhee. November 1978, iii +43 p., 21 figs., 28 tables.

415. A basis for classifying western Atlantic Sciaenidae (Teleostei: Perciformes). By Labbish Ning Chao. September 1978, v + 64 p., 41 figs., 1 table.

416. Ocean variability: Effects on U.S. marine fishery resources 1975. (20 papers.) By Julien R. Goulet, Jr. and Elizabeth D. Haynes, Editors. December 1978, iii +350 p.

417. Guide to the identification of genera of the fish Order Ophidiiformes with a tentative classification of the order. By Daniel M. Cohen and Jørgen G. Nielsen. December 1978, vii + 72 p., 103 figs., 2 tables. 
NOAA Technical Report NMFS Circular 430

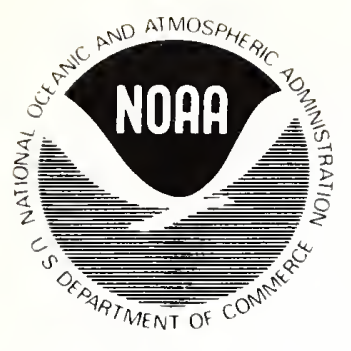

\author{
Guide to Identification of \\ Some Sculpin (Cottidae) \\ Larvae from Marine and \\ Brackish Waters off Oregon \\ and Adjacent Areas in \\ the Northeast Pacific
}

Sally L. Richardson and Betsy B. Washington

January 1980

U.S. DEPARTMENT OF COMMERCE

Juanita M. Kreps, Secretary

National Oceanic and Atmospheric Administration

Richard A. Frank, Administrator

National Marine Fisheries Service

Terry L. Leitzell, Assistant Administrator for Fisheries 
The National Marine Fisheries Service (NMFS) does not approve, recommend or endorse any proprietary product or proprietary material mentioned in this publication. No reference shall be made to NMFS, or to this publication furnished by NMFS, in any advertising or sales promotion which would indicate or imply that NMFS approves, recommends or endorses any proprietary product or proprietary material mentioned herein, or which has as its purpose an intent to cause directly or indirectly the advertised product to be used or purchased because of this NMFS publication. 


\section{CONTENTS}

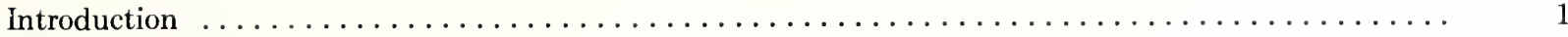

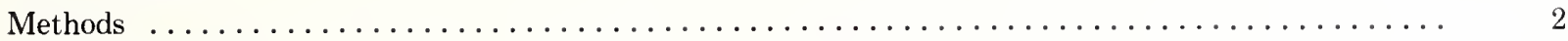

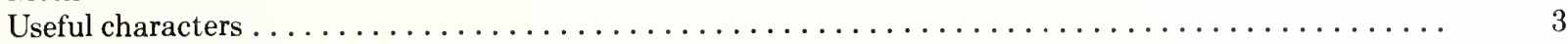

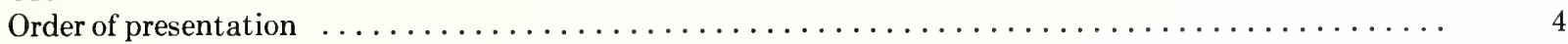

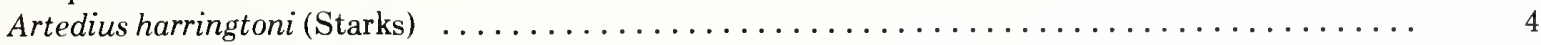

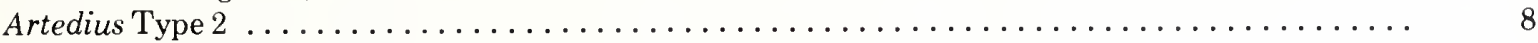

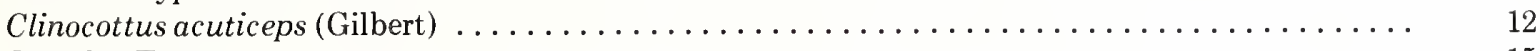

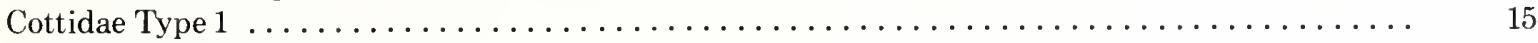

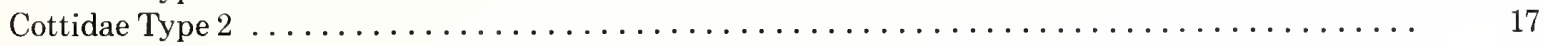

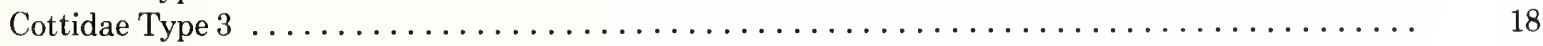

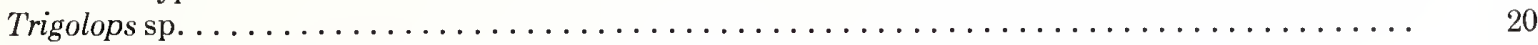

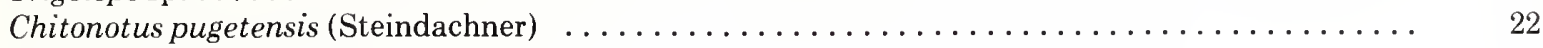

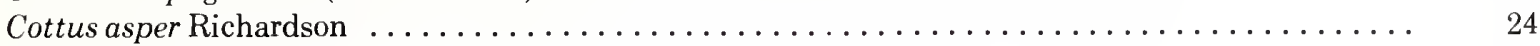

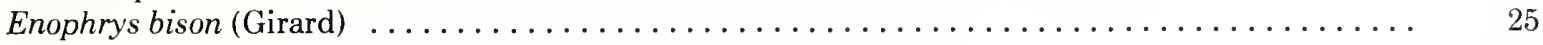

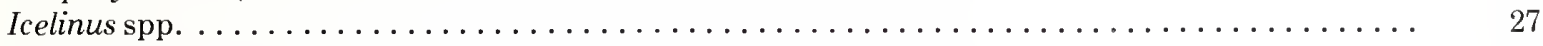

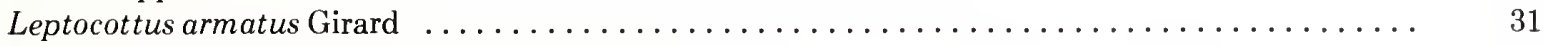

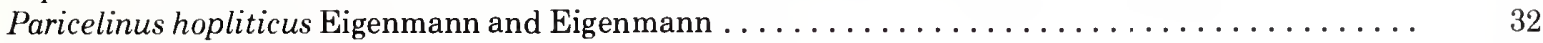

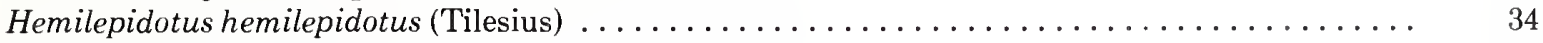

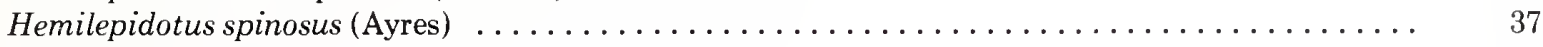

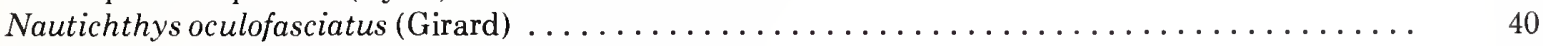

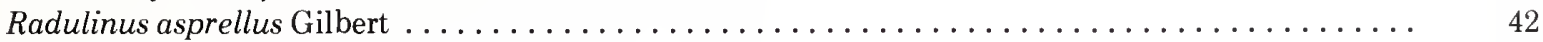

Radulinus boleoides Gilbert ..................................... 44

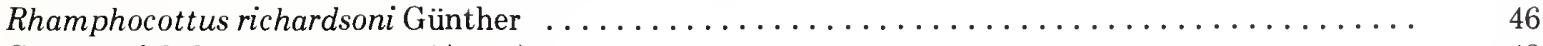

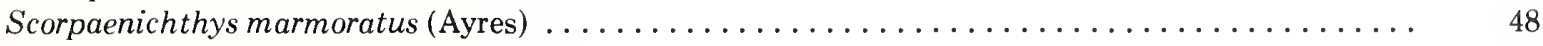

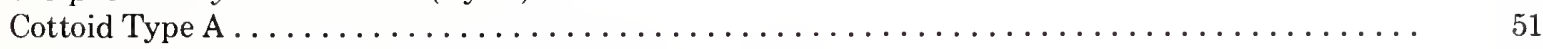

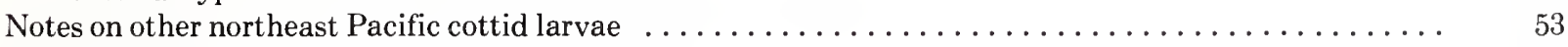

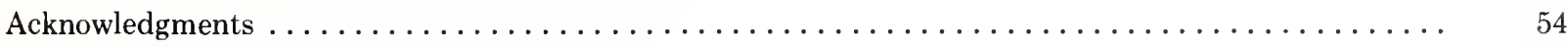

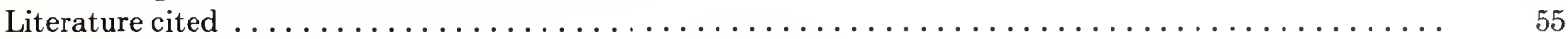

Figures

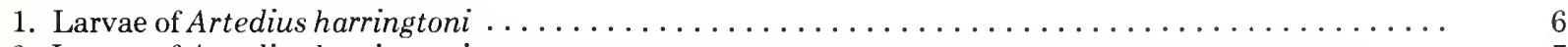

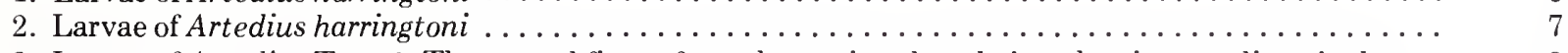

3. Larvae of Artedius Type 2. The second figure from the top is a dorsal view showing gut diverticula ... 9

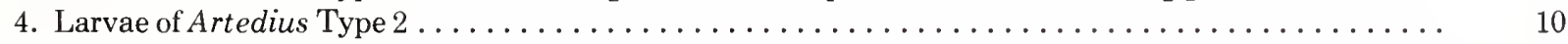

5. Larvae of Clinocottus acuticeps. The second figure from the top is a ventral view showing hindgut

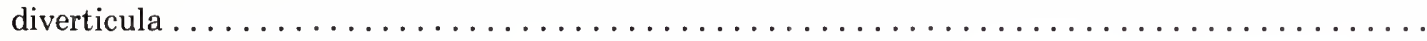

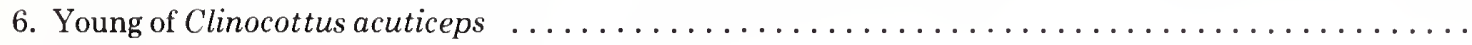

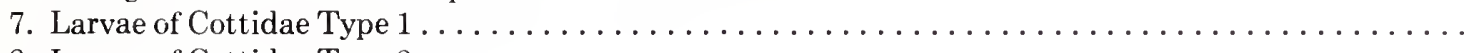

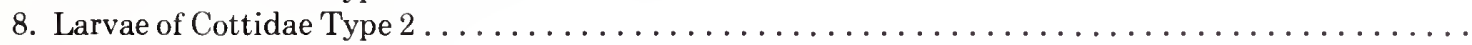

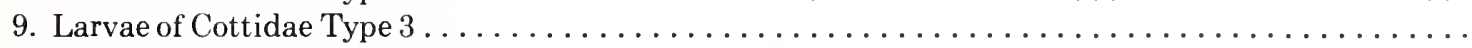

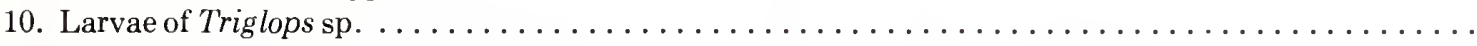

11. Larvae of Chitonotus pugetensis . . . . . . . . . . . . . . . . . . . . .

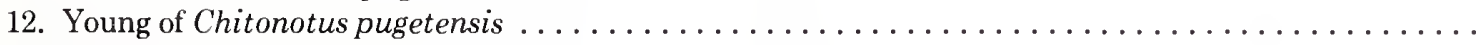

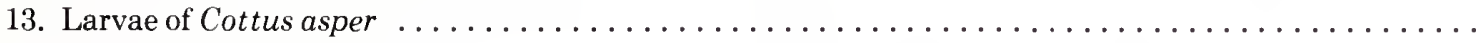

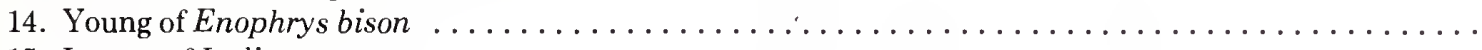

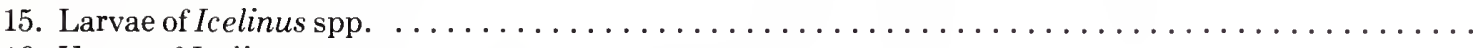

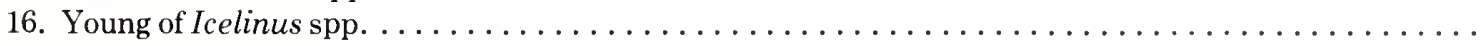

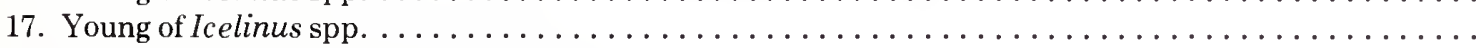

18. Larvae of Leptocottus armatus . . . . . . . . . . . . . . . . . . . . . . .

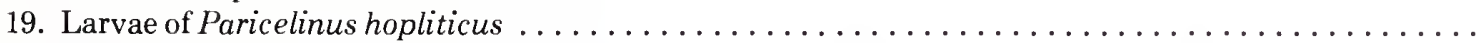

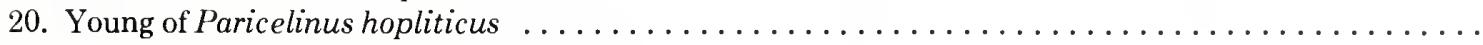

21. Larvae of Hemilepidotus hemilepidotus . . . . . . . . . . . . . . . . . . . . . . .

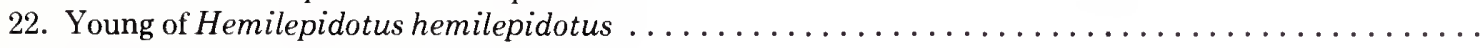

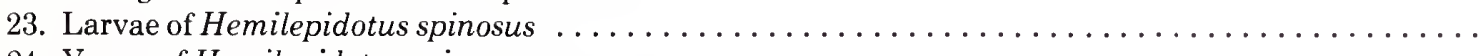

24. Young of Hemilepidotus spinosus . . . . . . . . . . . . . . . . . . . . .

25. Larvae of Nautichthys oculofasciatus . . . . . . . . . . . . . . . . . . . . . .

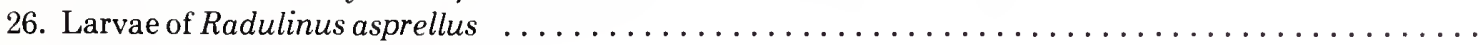

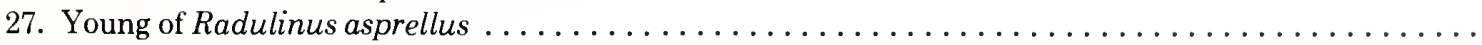




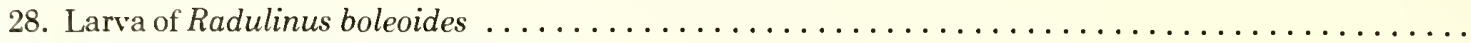

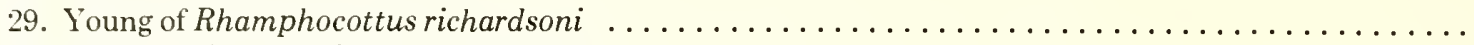

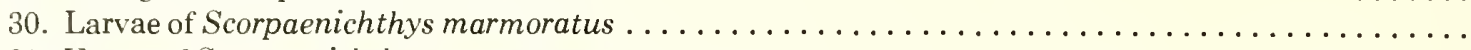

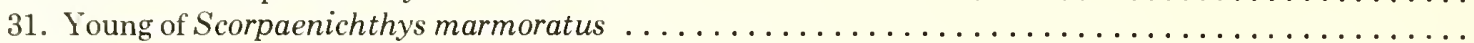

32. Larvae of Cottoid Type A . . . . . . . . . . . . . . . . . . . . . . .

\section{Tables}

1. Species of adult cottids whose range of distribution reportedly includes marine or brackish waters off

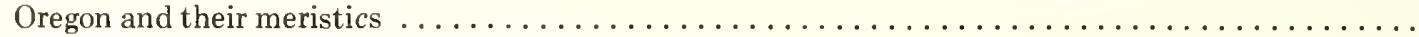

2. Groupings of cottid larvae described in this guide based on preopercular spines and pigment pat-

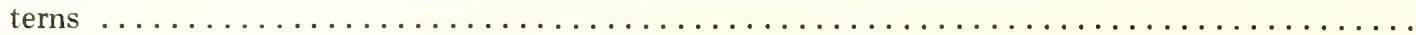

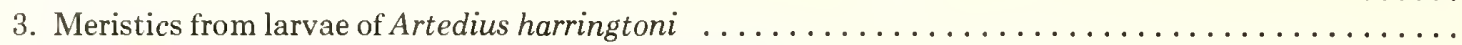

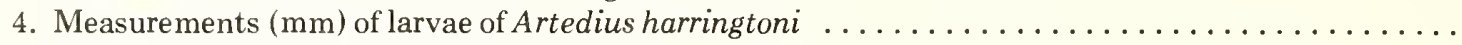

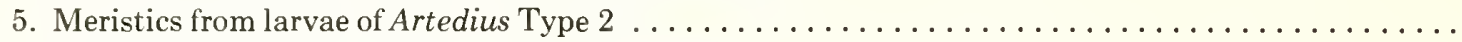

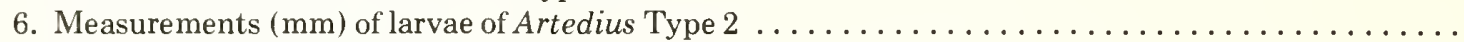

7. Meristics from young of Clinocottus acuticeps . . . . . . . . . . . . . . . . . . .

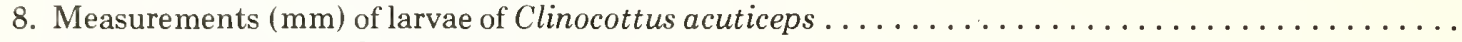

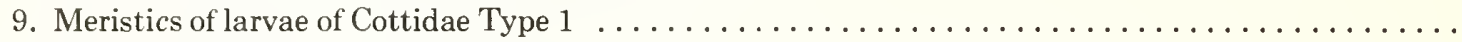

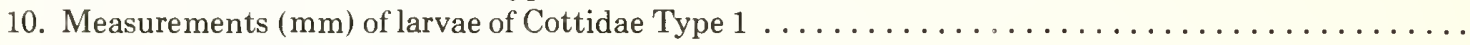

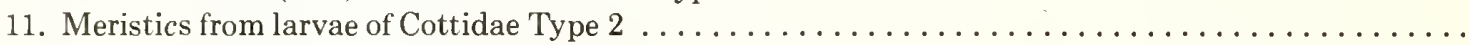

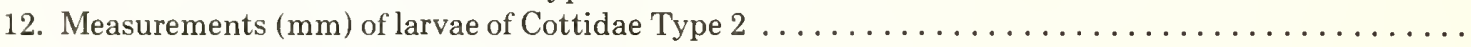

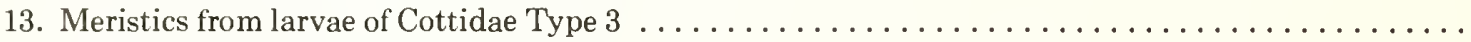

14. Measurements $(\mathrm{mm})$ of larvae of Cottidae Type $3 \ldots \ldots \ldots \ldots \ldots \ldots \ldots$

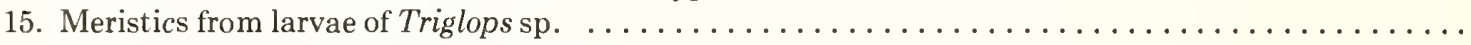

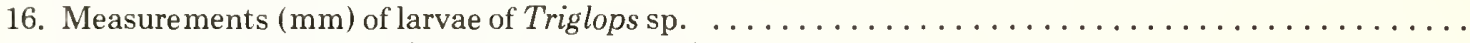

17. Meristics from larvae of Chitonotus pugetensis $\ldots \ldots \ldots \ldots \ldots \ldots \ldots \ldots$

18. Measurements $(\mathrm{mm})$ of larvae of Chitonotus pugetensis $\ldots \ldots \ldots \ldots \ldots \ldots \ldots$

19. Meristics from larvae of Cottus asper . . . . . . . . . . . . . . . . . . . . .

20. Measurements $(\mathrm{mm})$ of larvae of Cottus asper . . . . . . . . . . . . . . . . . . . .

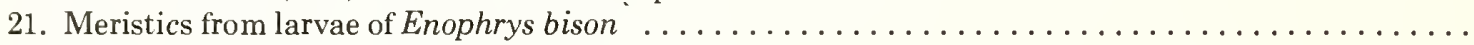

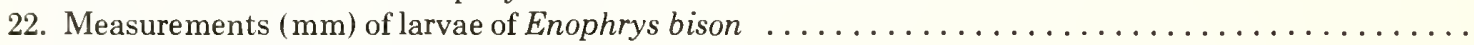

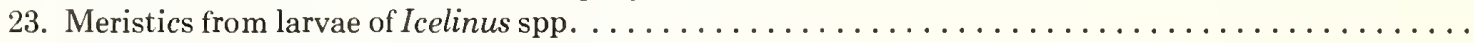

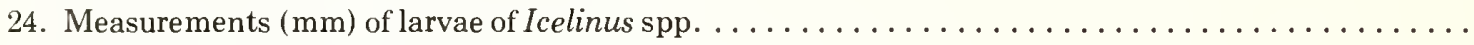

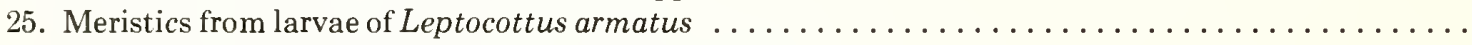

26. Measurements $(\mathrm{mm})$ of larvae of Leptocottus armatus . . . . . . . . . . . . . . . . . .

27. Meristics from young of Paricelinus hopliticus . . . . . . . . . . . . . . . . . . . .

28. Measurements $(\mathrm{mm})$ of young of Paricelinus hopliticus $\ldots \ldots \ldots \ldots \ldots \ldots \ldots$

29. Meristics from young of Hemilepidotus hemilepidotus . . . . . . . . . . . . . . . . . . . .

30. Measurements $(\mathrm{mm})$ of young Hemilepidotus hemilepidotus . . . . . . . . . . . . . . . .

31. Meristics from young of Hemilepidotus spinosus . . . . . . . . . . . . . . . . . . .

32. Measurements $(\mathrm{mm})$ of young of Hemilepidotus spinosus . . . . . . . . . . . . . . . . . . .

33. Meristics from larvae of Nautichthys oculofasciatus . . . . . . . . . . . . . . . . . . .

34. Measurements $(\mathrm{mm})$ of larvae of Nautichthys oculofasciatus . . . . . . . . . . . . . . . . .

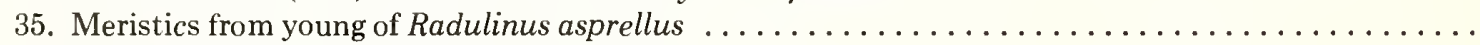

36. Measurements $(\mathrm{mm})$ of young of Radulinus asprellus $\ldots \ldots \ldots \ldots \ldots \ldots \ldots$

37. Meristics from larvae of Radulinus boleoides . . . . . . . . . . . . . . . . . . . . .

38. Measurements $(\mathrm{mm})$ of larvae of Radulinus boleoides . . . . . . . . . . . . . . . . . . . .

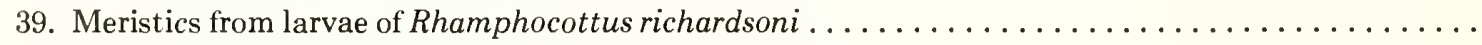

40. Measurements $(\mathrm{mm})$ of larvae of Rhamphocottus richardoni . . . . . . . . . . . . . .

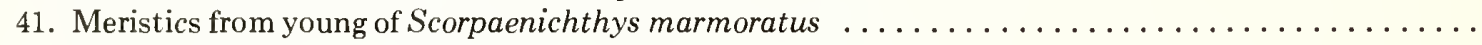

42. Measurements $(\mathrm{mm})$ of young of Scorpaenichthys marmoratus $\ldots \ldots \ldots \ldots \ldots$

43. Meristics from larvae of Cottoid Type A . . . . . . . . . . . . . . . . . . . . .

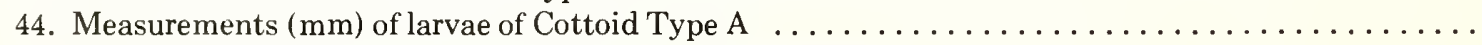

45. Additional northeast Pacific cottid species for which larvae are known 


\title{
Guide to Identification of Some Sculpin (Cottidae) Larvae from Marine and Brackish Waters off Oregon and Adjacent Areas in the Northeast Pacific
}

\author{
Sally L. Richardson ${ }^{1}$ and Betsy B. Washington ${ }^{2}$
}

\begin{abstract}
Knowledge of identification of cottid larvae taken in plankton collections off Oregon is summarized. Included are descriptions of 21 kinds of cottid larvae representing at least 14 of the 40 genera of cottids reported to occur in the northeast Pacific between Baja California and the Aleutian Islands. Larvae of Artedius harringtoni, Chitonotus pugetensis, Clinocottus acuticeps, Icelinus spp., Paricelinus hopliticus, Radulinus asprellus, $R$. boleoides, and four unidentified types are deseribed for the first time. A larval series of a second kind of Artedius is described with a discusion of problems of specific identification. New and comparative information is provided for larvae of Cottus asper, Enophrys bison, Hemilepidotus hemilepidotus, H. spinosus, Leptocottus armatus, Nautichthys oculofasciatus, Rhamphocottus richardsoni, Scorpaenichthys marmoratus, and Triglops sp.

Each descriptive account contains illustrations, a literature summary, distinguishing features (including size at hatching and transformation, pigmentation, head spination, general morphology), and a discussion of identification problems. Characters found to be most useful in distinguishing cottid larvae include morphology, pigmentation, head spination, and meristics.

Literature summaries are also provided for northeast Pacific cottid larvae in 8 additional genera: Blepsias, Dasycottus, Gilbertidia, ?Malacocottus, Myoxocephalus, Oligocottus, Orthonopias, Psychrolutes.
\end{abstract}

\section{INTRODUCTION}

The cottids are one of the most speciose and diverse groups of fishes inhabiting coastal waters of the northeast Pacific Ocean with 90 species in 40 genera reported to occur from Baja California to the Aleutian Islands (Howe and Richardson ${ }^{3}$ ). The range of 36 of these species in 20 genera reportedly includes waters off Oregon (Table 1). Adult cottids range in size from the 5 $\mathrm{cm}$ Artedius meanyi, Clinocottus acuticeps, and Oligocottus rimensis to the $76 \mathrm{~cm}$ Myoxocephalus polyacanthoceihalus and Scorpaenichthys marmoratus (Hart 1973). Larger forms in the genera Gymnocanthus, Hemilepidotus, Hemitripterus, Melletes, and Myoxocephalus are fished commercially by the U.S.S.R. and Japan (Gorbonova 1964; Fedorov 1973). Off Oregon several species are taken frequently by sports fishermen, e.g., Enophrys bison, Hemilepidotus hemilepidotus, H. spinosus, Leptocottus armatus, Scorpaenichthys marmoratus (Beardsley and Bond 1970).

\footnotetext{
${ }^{1}$ School of Oceanography, Oregon State University, Corvallis, Oreg.; present address: Gulf Coast Research Laboratory, East Beach Drive, Ocean Springs, MS 39564.

${ }^{2}$ School of Oceanography, Oregon State University, Corvallis, OR 97330 .

${ }^{5}$ Howe, K., and S. L. Richardson. 1978. Taxonomic review and meristic variation in marine sculpins (Osteichthys: Cottidae) of the northeast Pacific Ocean. Final Report, NOAA NMFS Contract No. 0378-M02-120, 1 January 1978 to 30 September 1978, 142 p. Northwest and Alaska Fisheries Center, National Marine Fisheries Service, NOAA, 2725 Montlake Blvd. East, Seattle, WA 98102.
}

Most, if not all cottid larvae hatch from demersal eggs $\sim$ (about)1-4 $\mathrm{mm}$ in diameter (Breder and Rosen 1966) and range from approximately 3 to $12 \mathrm{~mm}$ at hatching. They are usually pelagic and some are primarily neustonic, i.e., occurring at the surface of the water column, such as Scorpaenichthys marmoratus and Hemilepidotus spinosus (unpubl. data). Most cottid larvae probably transform to juveniles by $\sim 20 \mathrm{~mm}$ SL.

Cottid larvae are collected frequently in the coastal zone of temperate and boreal areas of the northeast Pacific but they are usually not abundant. In a $1 \frac{1 / 2}{y r}$ survey off Oregon they occurred in $80 \%$ of the samples but comprised only $8 \%$ of the fish larvae captured in a coastal assemblage of larval fishes $2-28 \mathrm{~km}$ offshore (Richardson $1977^{4}$; Richardson and Pearcy 1977). They were taken in all months of the year in that study.

A wide variety of larval forms is demonstrated within the cottid family. Identification of the larvae is often difficult because of the large number of species in the family, because of difficulty in establishing developmental series from the small numbers of larvae in plankton samples, and because relatively few species have been described in detail.

This report summarizes knowledge of identification of cottid larvae taken primarily in plankton and neuston

\footnotetext{
${ }^{4}$ Richardson, S. L. 1977. Larval fishes in ocean waters off Yaquina Bay, Oregon: abundance, distribution, and seasonality January 1971 to August 1972. Oreg. State Univ., Sea Grant Coll. Prog. Publ. No. ORESU-T-77-003, $73 \mathrm{p}$.
} 
Table 1.-Species of adult cottids whose range of distribution reportedly includes marine or brackish waters off Oregon and their meristics.' Branchiostegal rays number 6 unless otherwise noted.

\begin{tabular}{|c|c|c|c|c|c|c|}
\hline Species & $\begin{array}{l}\text { Dorsal } \\
\text { fin } \\
\text { spines }^{2}\end{array}$ & $\begin{array}{c}\text { Dorsal } \\
\text { fin } \\
\text { soft } \\
\text { rays }^{2}\end{array}$ & $\begin{array}{l}\text { Anal } \\
\text { fin } \\
\text { rays }\end{array}$ & $\begin{array}{l}\text { Pectoral } \\
\text { fin rays }\end{array}$ & $\begin{array}{c}\text { Pelvic } \\
\text { fin rays }\end{array}$ & $\begin{array}{c}\text { Total } \\
\text { vertebrae }\end{array}$ \\
\hline Artedius corallinus & VIII-IX & $15-16$ & $12-13$ & $14-16$ & 3 & $31-33$ \\
\hline Artedius fenestralis & VIII-IX & $16-18$ & $12-14$ & $14-16$ & 3 & $32-35$ \\
\hline Artedius harringtoni ${ }^{7}$ & IX & $15-18$ & $10-14$ & $13-15$ & 3 & $32-34$ \\
\hline Artedius lateralis & VII-X & $15-17$ & $12-14$ & $14-16$ & 3 & $32-34$ \\
\hline Artedius meanyi & $\mathrm{IX} \cdot \mathrm{X}$ & $14-17$ & $10-12$ & $14-16$ & $2.3^{*}$ & $33-35$ \\
\hline Artedius notospilotus & $\mathrm{IX}-\mathrm{X}$ & $14-16$ & $11-13$ & $14-17$ & 3 & $32-34$ \\
\hline Ascelichthys rhodorus & VII-X & $17 \cdot 19$ & $13-16$ & $16-18$ & 0 & $33-36$ \\
\hline Blepsias cirrhosus & VI-VIII & $20-24$ & $18-21$ & $11-13$ & 3 & $37-38$ \\
\hline Chitonotus pugetensis & VIII-XI & $14-17$ & $14-17$ & $16-18$ & $2-3^{*}$ & $35-36$ \\
\hline Clinocottus acuticeps & VII-IX & $13-17$ & $9-13$ & $13-15$ & 3 & $31-33$ \\
\hline Clinocottus embryum & VIII-X & $14-17$ & $9-12$ & $12-15$ & 3 & $33-34$ \\
\hline Clinocottus globiceps & VIII-X & $13 \cdot 17$ & $11-12$ & $13-15$ & 3 & $32-34$ \\
\hline Clinocottus recalvus & VIII-IX & $14-16$ & $9-13$ & $13-15$ & 3 & $32-33$ \\
\hline Cottus aleuticus & VIII-X & $16-20$ & $12-16$ & $13-16$ & 4 & $34-39$ \\
\hline Cottus asper & VII-XI & $18-21$ & $14-18$ & $14-17$ & 4 & $34-39$ \\
\hline Enophrys bison & VII-IX & $9 \cdot 13$ & $8-10$ & $15-17$ & $3-4^{*}$ & $29-31$ \\
\hline Hemilepidotus hemilepidotus & $\mathrm{X}$-XIII & $18-20$ & $13-16$ & $15-17$ & 4 & $35-37$ \\
\hline Hemilepidotus spinosus & $\mathrm{X}-\mathrm{XI}$ & $18-20$ & $14-16$ & $14-16$ & 4 & $35-37$ \\
\hline Icelinus burchami & X-XI & $16-18$ & $12-14$ & $16-19$ & 2 & $35-37$ \\
\hline Icelinus filamentosus & X-XII & $15-17$ & $13-16$ & $16-18$ & 2 & $34-37$ \\
\hline Icelinus oculatus & $\mathrm{XI}$ & $15-17$ & $13-14$ & 17 & 2 & 37 \\
\hline Icelinus tenuis & IX-XI & $16-18$ & $14-17$ & $15-17$ & 2 & $37-39$ \\
\hline Jordania zonope & XVII-XVIII & $15-18$ & $22-24$ & $13-15$ & $4-5^{*}$ & $46-48$ \\
\hline Leptocottus armatus & VI-VIII & $15-20$ & $15-20$ & $17-20$ & 4 & $35-39$ \\
\hline Nautichthys oculofasciatus & VIII-IX & $27-30$ & $16-21$ & $13-14$ & 3 & $40-41$ \\
\hline Oligocottus maculosus & VIII-IX & $15-18$ & $12-14$ & $12-15$ & 3 & $33-34$ \\
\hline Oligocottus rimensis & VIII-X & $16-19$ & $13-15$ & $13-15$ & 3 & $34-37$ \\
\hline Oligocottus snyderi & VII-IX & $17-20$ & $12-15$ & $12-15$ & 3 & $34-37$ \\
\hline Paricelinus hopliticus & XII-XIII & $19-20$ & $23-24$ & $14-15$ & 5 & 42 \\
\hline Psychrolutes phrictus ${ }^{4}$ & VII-IX & $19-20$ & $12-14$ & $22-26$ & 3 & $33-35$ \\
\hline Radulinus asprellus & VIII-X & $20-23$ & $21-25$ & $17-20$ & 3 & $38-39$ \\
\hline Radulinus boleoides & VIII-XI & $20-22$ & $21-23$ & $18-20$ & 3 & $39-40$ \\
\hline Rhamphocottus richardsoni & VII-IX & $12-14$ & $6-8$ & $14-16$ & $3^{*}-4$ & $26-28$ \\
\hline Scorpaenichthys marmoratus & VIII-XII & $15-19$ & $11-14$ & $14-16$ & $4-5^{*}$ & $35-37$ \\
\hline Synchirus gilli & VIII-X & $19-21$ & $18-21$ & $21 \cdot 24$ & 3 & $38-39$ \\
\hline Zesticelus profundorum & V-VII & $10-13$ & $8-11$ & $19-21$ & $2^{*}-3$ & $25-26$ \\
\hline
\end{tabular}

'From compilation by Howe and Richardson 1978 (see text footnote 3) which incorporated data from literature sources and original counts.

${ }^{2}$ Includes all fin ray elements whether or not they arise from the same pterigiophore.

"Includes hypural.

${ }^{1}$ Has 7 branchiostegal rays instead of the usual 6 .

May have 6 or 7 branchiostegal rays.

* Most frequent count.

collections off the Oregon coast. Included are descriptions and illustrations of complete or partial developmental series of 21 kinds of cottid larvae. These represent all but one form of cottid larvae from Oregon waters for which identified (as species or type) material is available in the Oregon State University Larval Fish Reference Collection. Although keys are not provided, larvae are grouped together on the basis of common larval characters. Occurrences, including seasonality, inshore-offshore distribution and relative abundance of most of these cottid larvae off Oregon have been reported by Richardson (see footnote 4) and Richardson and Pearcy 1977. However, relevant new information on occurrences is presented where appropriate. Knowledge of other cottid larvae from the northeast Pacific is summarized from the literature and personal observation.
This paper provides a basis for comparison with additional cottid species whose larvae remain to be identified and described. It is primarily descriptive in nature. Examination of relationships withinin the northeast Pacific Cottidae based on larval morphology is presented elsewhere (Richardson in press).

\section{METHODS}

Specimens came primarily from over 1,000 plankton and neuston samples collected off Oregon since 1969, which contained over 2,000 cottid larvae. During the course of working out identifications additional material was examined from plankton collections taken off northern California, Washington, Puget Sound, British Columbia, and Alaska (see Acknowledgments). Some 
transforming and juvenile specimens collected from Oregon tidepools were also examined. All material had been preserved in either 5 or $10 \%$ Formalin and some specimens had been transferred to 36 or $40 \%$ isopropyl alcohol.

Developmental terminology generally follows Ahlstrom et al. (1976) where the larval period is separated into three stages, preflexion, flexion, and postflexion, on the basis of the relative position of the notochord tip. Some subjectivity is involved in deciding the exact size at which the notochord begins to flex and when it is in a fully flexed position, but we tried to be consistent in judgment in all of the series. The transition from postflexion larva to juvenile could not be precisely defined in most series because of lack of specimens in the critical size range. Generally, the transformation to juvenile is accompanied by an increase in body pigmentation, scale formation, and completion of development of all fin rays. We refer to fish as postflexion larvae until they have attained an adult body form which characterizes them as juveniles.

Counts of various body parts were usually made on unstained specimens. When adequate material was available, a developmental series or several specimens were stained using the method of Taylor (1967). In unstained specimens fin rays were counted if any elements were visible. In stained specimens, fin rays were counted if any part absorbed stain. Fin ray counts include all ray elements whether or not they arise from the same pterygiophore. Vertebral counts include the urostyle.

Measurements were made following definitions given by Richardson and Laroche (1979) except: Body length $=$ snout tip to notochord tip preceding development of caudal fin [notochord length $(\mathrm{NL})$ ], then to posterior margin of hypural plate [standard length (SL)]. This applies to all lengths given in this paper unless noted otherwise. Snout length $=$ horizontal distance from tip of snout to anterior margin of pigmented region of left eye. Eye diameter = greatest diameter of pigmented portion of eye. Preopercular spine length (second spine) $=$ from tip to basal insertion of core of spine. Head length is abbreviated as HL.

Head spine terminology in cottid larvae has not been well defined. Many spines present during larval development are not present or obvious in adults and names used for spines in adults are often inconsistent. A standard terminology for spines in larval cottids, based on studies of developmental osteology of many species, remains to be proposed. In this paper, names used have been generally adapted from those that Richardson and Laroche (1979) diagramed for larvae and juveniles of Sebastes spp. for which similar problems exist. Some deviations from their terminology for Sebastes spp. exist in cottids. Preopercular spines along the posterior margin frequently number 4 but sometime may be multiple (over 5 ) serrations or small spines, rather than 5 as in Sebastes spp. Additional terms used here include: spines in the parietal region (several spines in the vicinity of the parietal spines of Sebastes spp., sometimes called occipital spines in adult cottids); spines in the posttemporal-supracleithral region Iseveral spines in the vicinity of the posttemporal and supracleithral spines of Sebastes spp., the basal origin of which could not be determined on unstained cottid larvae (not to be confused with spiny scales that develop in this region along the lateral line)]; anterior parietal spine or bump (apparently on the parietal ridge anterior to the principle parietal spine); midopercular spine (near the middle of the posterior margin of the opercle).

Illustrations were made with the aid of camera lucida. They are intended to accurately represent numbers of myomeres, fin rays including ray elements and bases, head spines, scales, and ventral midline melanophores.

Identifications in most cases could be made using adult characters, primarily meristic (Table 1; Howe and Richardson footnote 3) on the largest larvae in a series linked together by pigment and head spine patterns. Additional adult characters used to confirm identifications included deep emargination between dorsal fin spines 3 and 4 in Chitonotus pugetensis, attachment of inner pelvic ray to belly by membrane in Clinocottus acuticeps, number of dorsal scale rows and scales above the lateral line in Hemilepidotus hemilepidotus and $H$. spinosus, elongated first dorsal fin in Nautichthys oculofasciatus, and unique shape in Rhamphocottus richardsoni. Identification of larvae of Radulinus boleoides was based on their similarity to $R$. asprellus. Newly hatched, reared larvae of Hemilepidotus hemilepidotus, Dunn ${ }^{5}$ helped confirm the identification of small larvae in that series.

The descriptive format is designed to present a concise account of a combination of characters which, together with meristics (not included in the descriptions), will help to distinguish each of the kinds of larvae. Available literature is summarized for each larval type and lengths are given for each specimen illustrated. Distinguishing features in each account include information on size at hatching and transformation, pigmentation, head spination, and general morphology. Discussions for each kind of larvae may include taxonomic problems, comparisons with similar species, and new occurrence data.

\section{USEFUL CHARACTERS}

Characters most useful to distinguish cottid larvae include general shape of the body and snout, unusual diverticula of the gut cavity, melanistic pigment patterns, head spination, and meristics. Body shape can range from short and stubby (Artedius harringtoni, Clinocottus acuticeps) to moderately long and slender (Icelinus spp., Triglops sp.). Cottid larvae have a distinctively coiled gut and the hindgut may trail below the body (Artedius harringtoni, Clinocottus acuticeps). Snout to anus length is usually $\sim 40-50 \%$ SL except in small $(<5 \mathrm{~mm})$ larvae where it may be less. However, some species have a rather long gut, $>60 \%$ SL (Clinocot-

\footnotetext{
${ }^{5}$ Dunn, J. R. 1973. Unpubl. data. Northwest and Alaska Fisheries Center, National Marine Fisheries Service, NOAA, 2725 Monilake Blvd. East, Seattle, WA 98102.
} 
tus acuticeps, Rhamphocottus richardsoni). Small $(<6$ $\mathrm{mm}$ ) cottid larvae have a very characteristically protruding snout which, with development, can vary considerably in its degree of pointedness (e.g., compare Scorpaenichthys marmoratus and Radulinus asprellus). Several forms have unusual gut diverticula or protrusions from the abdominal wall (Artedius Type 2, Clinocottus acuticeps) which serve as striking characters.

Pigment patterns can range from darkly pigmented forms such as Scorpaenichthys marmoratus and Radulinus asprellus where melanophores cover the entire body except the tail tip to relatively unpigmented forms such as Triglops sp. with melanophores only on the head and gut. In many species (Artedius harringtoni, Chitonotus pugetensis, Paricelinus hopliticus) the number, extent, spacing, and shape of the postanal ventral midline melanophores serve as diagnostic aids, even though these may decrease in number with development. Ranges and frequency of counts of these melanophores within developmental periods are useful. The presence or absence of nape pigment and/or head pigment, particularly in small $(<5 \mathrm{~mm})$ larvae, may be helpful in some cases (Artedius spp., Clinocottus spp., Enophrys spp.). The pattern and extent of pigment over the gut is useful in otherwise lightly pigmented forms. It may range from relatively heavy pigment over the entire gut (Paricelinus hopliticus, Triglops sp.) to relatively light concentrations over the dorsolateral surface only (Cottidae Type 1, Cottidae Type 2). Sometimes it appears in distinctive patterns (the bars in Leptocottus armatus, the distinctive round melanophores in Enophrys bison) although these patterns can be obscured in poorly or improperly preserved material.

Most cottid larvae develop four spines on the preopercle. However, some forms develop only one prominent spine (Rhamphocottus richardsoni) while others develop a large number, up to $\sim 25$, of smaller spines (Artedius spp.) on the preopercular margin. A single parietal and nuchal spine may develop (Icelinus spp.) or a cluster of smaller spines (Cottidae Type 1) or no spines at all (Leptocottus armatus). The same situation may prevail in the posttemporal-supracleithral region. One or more postocular spines may develop (Hemilepidotus spp., Triglops sp.) or they may be absent (Artedius spp.).

Certain meristic characters (Table 1), particularly when used in combinations, may be useful in identifying cottid larvae. While many species have between 32 and 37 vertebrae ( $=$ myomeres), counts at the low or high end of the range may be helpful, e.g., $>40$ in Triglops sp. and Nautichthys oculofasciatus and $<31$ in Enophrys bison. The number of pelvic fin rays ranges from 0 to 5 with 3 being the most common count. Relatively few genera have counts of 2 (e.g., Icelinus) or 5 (e.g., Paricelinus, Scorpaenichthys). Pectoral fin ray counts range from 12 to 26 for Oregon species and overlap in many, but counts at the low or high end of the scale help to single out some species. Also useful are dorsal and anal fin counts which for Oregon species range from 5 to 18 dorsal spines, 9 to 30 dorsal rays, and 6 to 25 anal rays. Ranges of these counts for a particular species are generally 4 or less. The difference between dorsal (D) and anal (A) soft ray counts may also be of help which is usually D $>$ A, e.g., by 3 to 5 rays in Artedius spp., Clinocottus spp., and Oligocottus spp. and $>9$ in Nauthichthys oculofasciatus. In some species the D and A counts are nearly equal (Leptocottus) and in some D $<\mathrm{A}$ (Paricelinus hopliticus).

Other characters that may be useful include size at hatching, size at transformation, and cirri patterns. The size at hatching, e.g., $\sim 3 \mathrm{~mm}$ in Artedius harringtoni vs. $\sim 12 \mathrm{~mm}$ in Hemitripterus americanus (Warfel and Merriman 1944; Okiyama and Sando 1976) and the size at transformation, e.g., $\sim 9 \mathrm{~mm}$ in Enophrys bison and $\sim 16$ $\mathrm{mm}$ in Chitonotus pugetensis, can serve as distinguishing characters. Head cirri patterns, which may be evident in older larvae, may be important in linking larvae with known juveniles. However, they appear to develop after the pelagic phase in a number of species, e.g., Icelinus spp., and may be of limited value.

\section{ORDER OF PRESENTATION}

To facilitate use of this guide, the larvae described herein have been grouped according to certain primary characters (Table 2). However, a formal dichotomous key is not provided as many species remain to be described and such a key could be misleading. Rather, groups are formed on the basis of the most outstanding larval characters. The two major groupings are based on preopercular spine pattern: group A, numerous $(>4)$; group B, 4 or less. Within group A, the larvae may be further distinguished by using a combination of characters including number of preopercular spines, number of ventral midline melanophores, number of parietal spines, and presence or absence of gut diverticulae. Within group B the larvae may be placed in four subgroups on the basis of postanal pigmentation. Within these four groups, larvae can be further separated using characters as for group A and relative body shape, pigmentation, and number of myomeres.

\section{Artedius harringtoni (Starks)}

(Figures 1, 2; Tables 3, 4)

Literature. A $4.2 \mathrm{~mm}$ SL larva resembling $A$. harringtoni was described by Blackburn (1973) as Cottid 6. Larvae of this species were referred to as Artedius sp. 1 by Richardson (see footnote 4), and Richardson and Pearcy (1977).

Distinguishing Features. Larvae of A. harringtoni are probably 3-4 mm long at hatching. The largest pelagic specimens we collected, $\sim 13-14 \mathrm{~mm}$, are beginning to develop juvenile pigmentation.

A dense concentration of malanophores is present over the gut. The nape is pigmented in all but a few of the smallest larvae although this pigment becomes embed- 
Table 2.-Groupings of cottid larvae described in this guide based on preopercular spines and pigment patterns.

\begin{tabular}{|c|c|c|c|c|c|}
\hline & $\begin{array}{c}\text { Preopercular } \\
\text { spines }\end{array}$ & $\begin{array}{c}\text { Ventral }^{1} \\
\text { midline } \\
\text { melano- } \\
\text { phores }\end{array}$ & $\begin{array}{c}\text { Parietal } \\
\text { spines }\end{array}$ & $\begin{array}{c}\text { Vertebrae }^{2} \\
\text { (myomeres) }\end{array}$ & $\begin{array}{c}\text { Additional } \\
\text { distinguishing characters }\end{array}$ \\
\hline \multicolumn{6}{|l|}{ A. Preopercular spines numerous $(>4)$} \\
\hline Artedius harringtoni & $11-21$ & $27-30$ & 0 & $32-34$ & \\
\hline Artedius Type 2 & $13-23$ & $14-24$ & Multiple & $(32-34)$ & dorsal gut diverticula \\
\hline Clinacottus acuticeps & $8-13$ & $7-9$ & 0 & $32-33$ & hindgut diverticula \\
\hline Cottidae Type 1 & 19 & 7 & Multiple & $(32-35)$ & \\
\hline Cottidae Type 2 & $10-11$ & $15-17$ & 1 & $(32-34)$ & hindgut bulges \\
\hline Cottidae Type 3 & $16-19$ & $4-5$ & Multiple & $(33)$ & \\
\hline \multicolumn{6}{|l|}{ B. Preopercular spines 4 or fewer } \\
\hline \multicolumn{6}{|l|}{ 1. Postanal pigment absent } \\
\hline \multicolumn{6}{|c|}{ 2. Postanal pigment on ventral midline only } \\
\hline Chitonotus pugetensis & 4 & $41-45$ & 1 & $35-36$ & \\
\hline Cattus asper & 4 & $14-17$ & 0 & $34-39$ & \\
\hline Enophrys bison & 4 & $11-14$ & 1 & $29-31$ & deep bodied \\
\hline Icelinus spp. & 4 & $10-11$ & 1 & $33-39$ & finfold pigment \\
\hline Leptacattus armatus & 4 & $9-11$ & 0 & $35-39$ & pigment bars on gut \\
\hline Paricelinus hopliticus & 4 & $31-32$ & 1 & 42 & dark gut \\
\hline \multicolumn{6}{|c|}{$\begin{array}{l}\text { 3. Postanal pigment primarily on dorsal } \\
\text { and ventral midline on small larvae }\end{array}$} \\
\hline Hemilepidotus hemilepidotus & 4 & 14 & 1 & $35-37$ & dorsal pigment interrupted \\
\hline Hemilepidotus spinosus & 4 & $24-34$ & 1 & $35-37$ & dorsal pigment continuous \\
\hline \multicolumn{6}{|l|}{ 4. Postanal pigment heavy over body } \\
\hline Nautichthys aculafasciatus & 4 & $\mathrm{~N}^{3}$ & $\mathrm{~B}^{3}$ & $40-41$ & large pectoral fins \\
\hline Radulinus asprellus & 4 & $\mathrm{~N}$ & 1 & $38-39$ & slender bodied \\
\hline Radulinus baleaides & $?$ & $\mathrm{~N}$ & $?$ & $39-40$ & \\
\hline Rhamphacottus richardsani & 1 & $\mathrm{~N}$ & 1 & $26-28$ & deep bodied \\
\hline Scarpaenichthys marmaratus & 4 & $\mathrm{~N}$ & B & $35-37$ & \\
\hline Cottoid Type A & 0 & $\mathrm{~N}$ & 0 & 35 & globose \\
\hline
\end{tabular}

'Maximum number at peak of development.

${ }^{2}$ From Howe \& Richardson 1978 (see text footnote 3).

${ }^{3} \mathrm{~N}=$ not distinguishable; $\mathrm{B}=$ bump.

Table 3.-Meristics from larvae of Artedius herringtoni. (Specimen between dashed line is undergoing notochord flexion.) [* = Specimen stained with Alizarin Red $\mathrm{S} ;{ }^{* *}=$ Dorsal fin spines and soft rays cannot be distinguished; $\mathrm{N}=$ Not examined.]

\begin{tabular}{|c|c|c|c|c|c|c|c|c|c|c|c|c|c|c|c|}
\hline \multirow{4}{*}{$\begin{array}{r}\text { Body } \\
\text { length }\end{array}$} & & & \multirow{4}{*}{$\begin{array}{l}\text { Anal } \\
\text { fin } \\
\text { rays }\end{array}$} & \multirow{3}{*}{\multicolumn{2}{|c|}{$\begin{array}{l}\text { Pectoral } \\
\text { fin rays }\end{array}$}} & \multirow{4}{*}{$\begin{array}{l}\text { Pelvic } \\
\text { fin } \\
\text { spine } \\
\text { \& rays } \\
\end{array}$} & \multirow{4}{*}{$\begin{array}{c}\text { Preoper- } \\
\text { cular } \\
\text { spines }\end{array}$} & \multirow{4}{*}{$\begin{array}{l}\text { Ventral } \\
\text { midline } \\
\text { melano- } \\
\text { phores }\end{array}$} & \multicolumn{4}{|c|}{ Caudal fin rays } & \multirow{2}{*}{\multicolumn{2}{|c|}{ Vertebrae }} & \multirow{4}{*}{$\begin{array}{c}\text { Branchi } \\
\text { ostegal } \\
\text { rays }\end{array}$} \\
\hline & \multirow{2}{*}{\multicolumn{2}{|c|}{ Dorsal fin }} & & & & & & & \multicolumn{2}{|c|}{ Dorsal } & \multicolumn{2}{|c|}{ Ventral } & & & \\
\hline & & & & & & & & & Second- & Prin- & Prin- & Second- & \multirow{2}{*}{$\begin{array}{l}\text { Abdom- } \\
\text { inal }\end{array}$} & \multirow{2}{*}{$\begin{array}{c}\text { Cau- } \\
\text { dal }\end{array}$} & \\
\hline & Spines & Rays & & Left & Right & & & & ary & cipal & cipal & ary & & & \\
\hline 3.0 & - & - & - & - & - & - & - & 29 & $\mathrm{~N}$ & $\mathrm{~N}$ & $\mathrm{~N}$ & $\mathrm{~N}$ & $\mathrm{~N}$ & $\mathrm{~N}$ & $\mathrm{~N}$ \\
\hline 4.7 & - & - & - & - & - & - & 12 & 27 & $\mathrm{~N}$ & $\mathrm{~N}$ & $\mathrm{~N}$ & $\mathrm{~N}$ & $\mathrm{~N}$ & $\mathrm{~N}$ & $\mathrm{~N}$ \\
\hline 6.9 & - & - & - & - & - & - & 16 & 30 & $\mathrm{~N}$ & $\mathrm{~N}$ & $\mathrm{~N}$ & $\mathrm{~N}$ & $\mathrm{~N}$ & $\mathrm{~N}$ & $\mathrm{~N}$ \\
\hline 7.3 & -17 & $* *$ & 13 & 14 & 14 & - & 16 & 26 & $\mathrm{~N}$ & $\mathrm{~N}$ & $\mathrm{~N}$ & $\mathrm{~N}$ & $\mathrm{~N}$ & $\mathrm{~N}$ & 7 \\
\hline 9.3 & IX & 16 & 13 & 14 & 14 & I,3 & 21 & 22 & $\mathrm{~N}$ & $\mathrm{~N}$ & $\mathrm{~N}$ & $\mathrm{~N}$ & $\mathrm{~N}$ & $\mathrm{~N}$ & 7 \\
\hline $11.2^{*}$ & IX & 17 & 14 & 14 & 14 & $\mathrm{I}, 3$ & 21 & $\mathrm{~N}$ & 5 & 6 & 6 & 3 & 11 & 23 & 7 \\
\hline 13.6 & IX & 17 & 13 & 15 & 15 & $\mathrm{I}, 3$ & 18 & 23 & $\mathrm{~N}$ & $\mathrm{~N}$ & $\mathrm{~N}$ & $\mathrm{~N}$ & $\mathrm{~N}$ & $\mathrm{~N}$ & 7 \\
\hline $13.6^{*}$ & IX & 17 & 13 & 14 & 14 & $\mathrm{I}, 3$ & 11 & $\mathrm{~N}$ & 4 & 6 & 6 & 3 & 12 & 22 & 7 \\
\hline
\end{tabular}

Table 4.-Measurements ( $\mathrm{mm}$ ) of larvae of Artedius harringtoni. (Specimen between dashed line is undergoing notochord flexion.)

\begin{tabular}{|c|c|c|c|c|c|c|c|c|}
\hline $\begin{array}{l}\text { Body } \\
\text { length }\end{array}$ & $\begin{array}{l}\text { Head } \\
\text { length }\end{array}$ & $\begin{array}{l}\text { Snout } \\
\text { length }\end{array}$ & $\begin{array}{c}\text { Eye } \\
\text { diameter }\end{array}$ & $\begin{array}{l}\text { Snout to } \\
\text { anus length }\end{array}$ & $\begin{array}{l}\text { Body depth } \\
\text { at pectoral } \\
\text { fin base }\end{array}$ & $\begin{array}{c}\text { Pectoral } \\
\text { fin length }\end{array}$ & $\begin{array}{l}\text { 2d preoper- } \\
\text { cular } \\
\text { spine length }\end{array}$ & $\begin{array}{c}\text { Farietal } \\
\text { spine length }\end{array}$ \\
\hline 3.0 & 0.66 & 0.16 & 0.32 & 1.3 & 0.72 & 0.12 & $\mathrm{~N}^{2}$ & - \\
\hline 4.7 & 0.82 & 0.20 & 0.39 & 1.6 & 1.1 & 0.31 & $\mathrm{~N}$ & - \\
\hline \\
\hline 6.9 & 1.8 & 0.39 & 0.58 & 3.3 & 1.6 & 0.47 & $\mathrm{~N}$ & - \\
\hline \multicolumn{9}{|c|}{ ( } \\
\hline 7.3 & 2.0 & 0.47 & 0.78 & 3.4 & 2.4 & 0.90 & $\mathrm{~N}$ & - \\
\hline 9.3 & 2.0 & 0.35 & 0.94 & 4.5 & 3.0 & 2.0 & $\mathrm{~N}$ & - \\
\hline 13.6 & 4.3 & 1.1 & 1.1 & 6.6 & 3.8 & 3.6 & $\mathrm{~N}$ & - \\
\hline
\end{tabular}

'Multiple spines develop along preopercular margin instead of usual $4 . \quad{ }^{2} \mathrm{~N}=$ Not measured. 

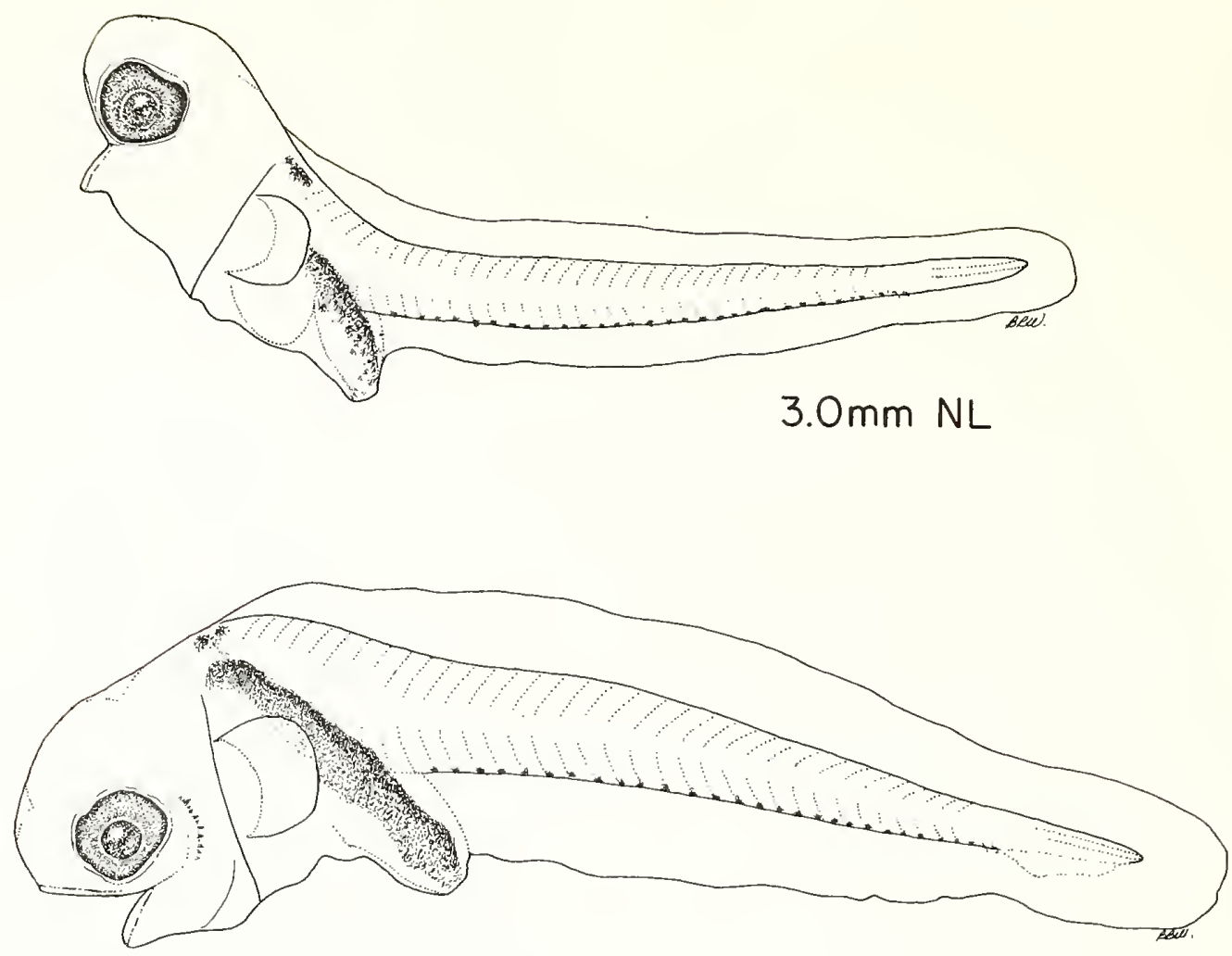

$4.7 \mathrm{~mm} \mathrm{NL}$

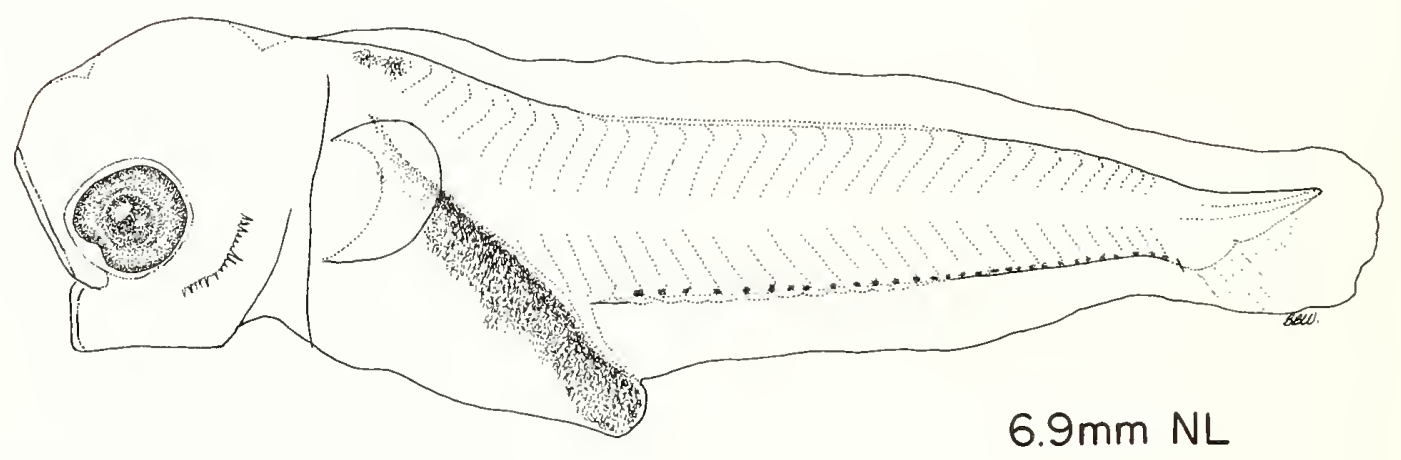

Figure 1.-Larvae of Artedius harringtoni. 

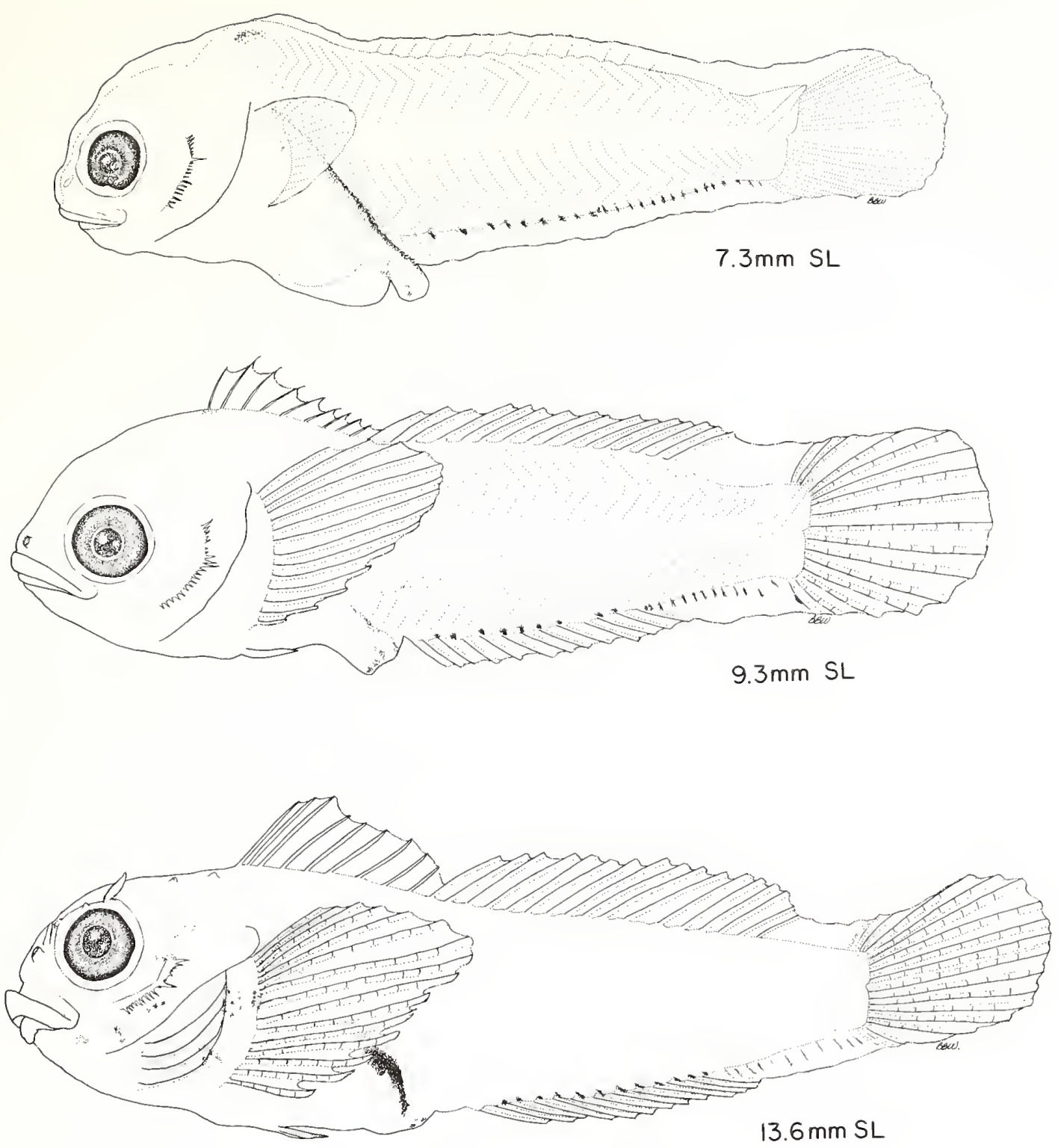

Figure 2.-Larvae of Artedius harringtoni.

ded in later stages, $>9 \mathrm{~mm}$. A row of $>20$ melanophores (often 20-30 but $>25$ in larvae $<6 \mathrm{~mm}$ ) occurs along the ventral midline beginning immediately behind the anus. The number of ventral midline melanophores helps to distinguish $A$. harringtoni from Artedius Type 2. The posterior half of these ventral melanophores characteristically extend as dashes of pigment out onto the finfold particularly in larvae $>7 \mathrm{~mm}$. Some pigment is added to the head region and pectoral fin base in the largest specimens $>12 \mathrm{~mm}$.

The preopercular margin develops a series of small spines which begin to appear in larvae $\sim 4.5-5.0 \mathrm{~mm}$. These increase in number to $\sim 20-25$ in postflexion larvae. The spines on the dorsal edge and at the posterior angle of the preopercle become the largest in the series. The number of preopercular spines becomes reduced in 
the largest specimens, possibly due to fusion or overgrowth by tissue. Artedius harringtoni never develops pronounced multiple spines in the parietal and posttemporal region as does Artedius Type 2 although minute serrations are sometimes visible and a bump develops in the parietal region in larger specimens.

Larvae of $A$. harringtoni are stubby in shape and often have a humped appearance in the nape region. The hindgut trails below the body. Snout to anus length is generally $<50 \%$ SL. Gut diverticula, or protrusions from the abdominal wall, are never present as in Artedius Type 2. Body depth at pectoral fin base ranges from about 23 to $33 \% \mathrm{SL}$. The length of the pectoral fin increases from 4 to $26 \%$ SL during larval development. Artedius harringtoni is the only species of Artedius with seven branchiostegal rays (Howe and Richardson footnote 3 ). Seven branchiostegals were countable in all larval specimens examined (25) down to $\sim 7 \mathrm{~mm}$. The innermost pair of branchiostegals is extremely fine and small in relation to the other six and may not be formed or indistinguishable on unstained specimens under $7 \mathrm{~mm}$. The adult complement or dorsal, anal, pectoral, and pelvic fin rays or ray elements can be counted in larvae $\sim 10 \mathrm{~mm}$.

Discussion. Identification of this series as $A$. harringtoni was based primarily on meristic characters, especially the presence of seven branchiostegal rays.
Relative abundance of adults in the area of larval capture was also helpful. Artedius harringtoni is one of the three most common species of Artedius in Oregon tidepools, together with $A$. lateralis and $A$. fenestralis $\left(\right.$ Howe $\left.^{6}\right)$. Cirri patterns on the largest specimens in our series compared with those known for these three species provided further evidence of their identity as $A$. harringtoni. Within these three species, only $A$. harringtoni has preorbital cirri and only $A$. harringtoni and $A$. lateralis have nasal cirri (Bolin 1944). Artedius harringtoni has 1 small cirrus at the base of each nasal spine while $A$. lateralis has 1 or 2 cirri at the base of each spine. The largest specimens in our series have a single nasal cirrus at the base of each spine and the largest specimen has small bumps in the preorbital region which may be developing cirri.

\section{Artedius Type 2}

(Figures 3, 4; Tables 5, 6)

Literature. Blackburn (1973) briefly described and illustrated $(8.5 \mathrm{~mm} \mathrm{SL}$ ) larvae resembling our Artedius

\footnotetext{
${ }^{6}$ K. Howe, Ph.D. candidate, Department of Fisheries and Wildlife, Oregon State University, Corvallis, OR 97331, pers. commun. September 1978
}

Table 5.-Meristics from larvae of Artedius Type 2. (Specimen between dashed line is undergoing notochord flexion.) $\left[{ }^{*}=\right.$ Specimen stained with Alizarin Red $\mathrm{S} ;{ }^{* *}=$ Dorsal fin spines and soft rays cannot be distinguished; $\mathrm{B}=\mathrm{Bases}$ only; $\mathrm{N}=\mathrm{Not}$ examined.]

\begin{tabular}{|c|c|c|c|c|c|c|c|c|c|c|c|c|c|c|c|}
\hline \multirow{4}{*}{$\begin{array}{l}\text { Body } \\
\text { length }\end{array}$} & & & \multirow{4}{*}{$\begin{array}{l}\text { Anal } \\
\text { fin } \\
\text { rays }\end{array}$} & \multirow{3}{*}{\multicolumn{2}{|c|}{$\begin{array}{c}\text { Pectoral } \\
\text { fin rays }\end{array}$}} & \multirow{4}{*}{$\begin{array}{c}\text { Pelvic } \\
\text { fin } \\
\text { spine } \\
\text { \& rays }\end{array}$} & \multirow{4}{*}{$\begin{array}{c}\text { Preoper- } \\
\text { cular } \\
\text { spines }\end{array}$} & \multirow{4}{*}{$\begin{array}{l}\text { Ventral } \\
\text { midline } \\
\text { melano- } \\
\text { phores }\end{array}$} & \multicolumn{4}{|c|}{ Caudal fin rays } & \multirow{2}{*}{\multicolumn{2}{|c|}{ Vertebrae }} & \multirow{4}{*}{$\begin{array}{c}\text { Branchi- } \\
\text { ostegal } \\
\text { rays }\end{array}$} \\
\hline & \multirow{2}{*}{\multicolumn{2}{|c|}{ Dorsal fin }} & & & & & & & \multicolumn{2}{|c|}{ Dorsal } & \multicolumn{2}{|c|}{ Ventral } & & & \\
\hline & & & & & & & & & Second- & Prin- & Prin- & Second- & \multirow{2}{*}{$\begin{array}{l}\text { Abdom- } \\
\text { inal }\end{array}$} & \multirow{2}{*}{$\begin{array}{c}\text { Cau- } \\
\text { dal }\end{array}$} & \\
\hline & Spines & Rays & & Left & Right & & & & ary & cipal & cipal & ary & & & \\
\hline 3.0 & - & - & - & - & $\mathrm{N}$ & - & - & 24 & $\mathrm{~N}$ & $\mathrm{~N}$ & $\mathrm{~N}$ & $\mathrm{~N}$ & $\mathrm{~N}$ & $\mathrm{~N}$ & $\mathrm{~N}$ \\
\hline 4.7 & - & - & 一 & 一 & $N$ & - & $\sim 5$ & 14 & $\mathrm{~N}$ & $\mathrm{~N}$ & $N$ & $\mathrm{~N}$ & $\mathrm{~N}$ & $\mathrm{~N}$ & $\mathrm{~N}$ \\
\hline & & & & & & & & & - & - & - & -- & - & $\cdots$ & $\cdots$ \\
\hline 6.0 & - & - & 一 & - & $\mathrm{N}$ & - & 13 & $\sim 15$ & $\mathrm{~N}$ & $\mathrm{~N}$ & $\mathrm{~N}$ & $\mathrm{~N}$ & $\mathrm{~N}$ & $\mathrm{~N}$ & $\mathrm{~N}$ \\
\hline & & & & & & - & 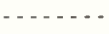 & $\cdots$ & $\cdots$ & - & - & 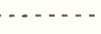 & - & - & - \\
\hline 7.3 & -14 & $B-* *$ & $12 \mathrm{~B}$ & - & $\mathrm{N}$ & - & 21 & 15 & $\mathrm{~N}$ & $\mathrm{~N}$ & $\mathrm{~N}$ & $\mathrm{~N}$ & $\mathrm{~N}$ & $\mathrm{~N}$ & 6 \\
\hline 9.9 & VIII & 18 & 12 & 15 & $\mathrm{~N}$ & 1,3 & 23 & 18 & $\mathrm{~N}$ & $\mathrm{~N}$ & $\mathrm{~N}$ & $\mathrm{~N}$ & $\mathrm{~N}$ & $\mathrm{~N}$ & 6 \\
\hline $11.5^{*}$ & IX & 16 & 12 & 15 & 15 & $\mathrm{I}, 3$ & 24 & $\mathrm{~N}$ & - & 6 & 4 & - & 12 & 22 & 6 \\
\hline 11.8 & IX & 17 & 13 & 15 & $\mathrm{~N}$ & I, 3 & 13 & 13 & $\mathrm{~N}$ & $\mathrm{~N}$ & $N$ & $\mathrm{~N}$ & $\mathrm{~N}$ & $\mathrm{~N}$ & 6 \\
\hline
\end{tabular}

Table 6.-Measurements ( $\mathrm{mm}$ ) of larvae of Artedius Type 2. (Specimen between dashed line is undergoing notochord flexion.)

\begin{tabular}{|c|c|c|c|c|c|c|c|c|}
\hline $\begin{array}{l}\text { Body } \\
\text { length }\end{array}$ & $\begin{array}{l}\text { Head } \\
\text { length }\end{array}$ & $\begin{array}{l}\text { Snout } \\
\text { length }\end{array}$ & $\begin{array}{c}\text { Eye } \\
\text { diameter }\end{array}$ & $\begin{array}{c}\text { Snout to } \\
\text { anus length }\end{array}$ & $\begin{array}{c}\text { Body depth } \\
\text { at pectoral } \\
\text { fin base }\end{array}$ & $\begin{array}{r}\text { Pectoral } \\
\text { fin length }\end{array}$ & $\begin{array}{l}\text { 2d preoper- } \\
\text { cular } \\
\text { spine length }\end{array}$ & $\begin{array}{c}\text { Parietal } \\
\text { spine length }^{2}\end{array}$ \\
\hline 3.0 & 0.66 & 0.18 & 0.30 & 1.2 & 0.58 & 0.22 & $\mathrm{~N}^{3}$ & $\mathrm{~N}$ \\
\hline 4.7 & 1.2 & 0.12 & 0.44 & 1.9 & 1.2 & 0.20 & $\mathrm{~N}$ & $\mathrm{~N}$ \\
\hline \multicolumn{9}{|c|}{ - } \\
\hline 6.0 & 1.7 & 0.35 & 0.56 & 2.8 & 1.5 & 0.31 & $\mathrm{~N}$ & $\mathrm{~N}$ \\
\hline \multicolumn{9}{|c|}{ - } \\
\hline 7.2 & 2.0 & 0.31 & 0.66 & 3.5 & 2.1 & 0.86 & $\mathrm{~N}$ & $\mathrm{~N}$ \\
\hline 9.9 & 3.0 & 0.48 & 0.94 & 4.6 & 2.8 & 1.7 & $\mathrm{~N}$ & $\mathrm{~N}$ \\
\hline 11.8 & 4.1 & 0.64 & 1.13 & 5.6 & 3.0 & 3.4 & $\mathrm{~N}$ & $\mathrm{~N}$ \\
\hline
\end{tabular}

${ }^{1}$ Multiple spines develop along preopercular margin instead of usual 4.

${ }^{2}$ Multiple spines develop in region of parietal spine.

${ }^{3} \mathrm{~N}=$ Not measured. 

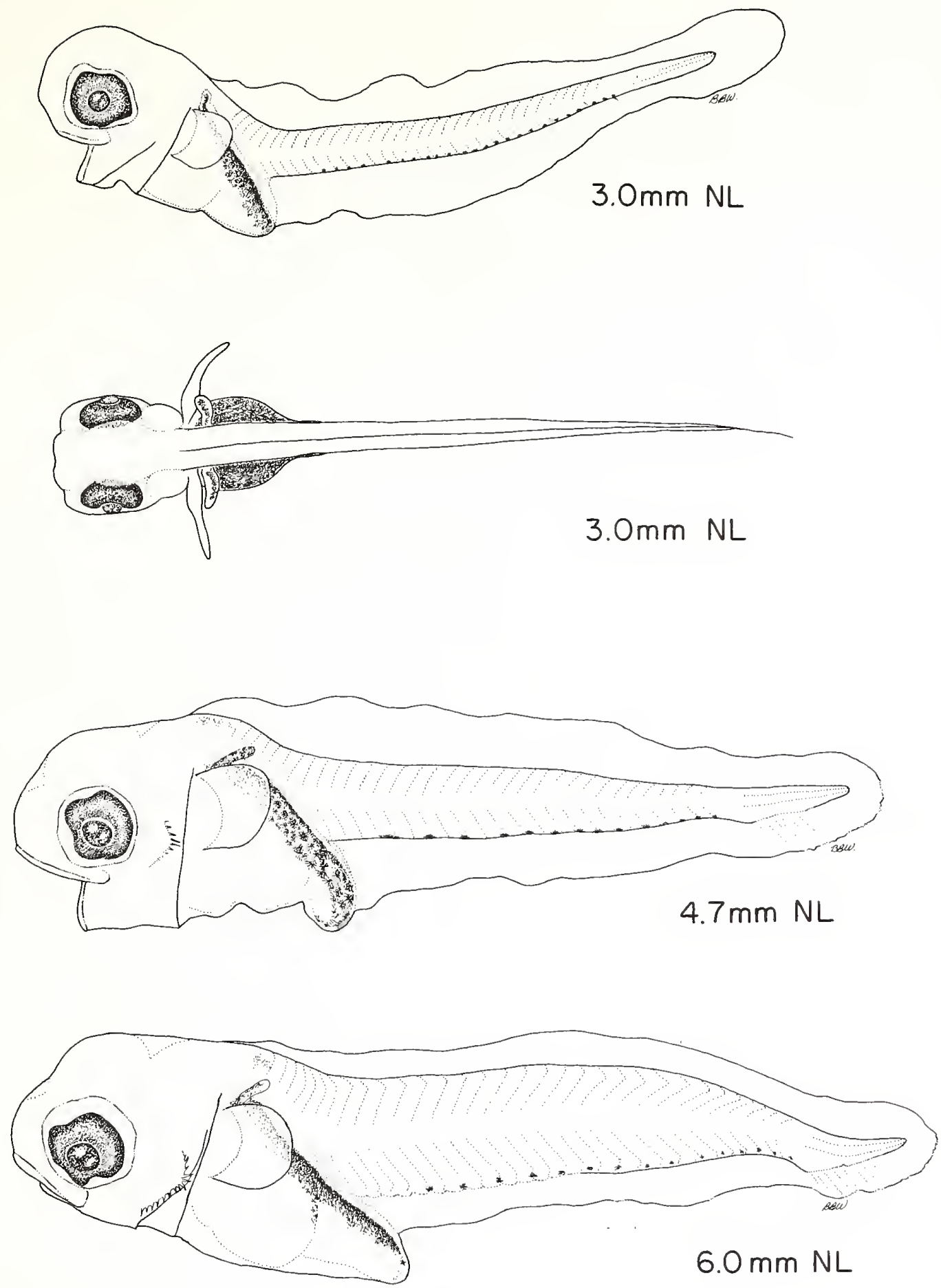

Figure 3.-Larvae of Artedius Type 2. The second figure from the top is a dorsal view showing gut diverticula. 

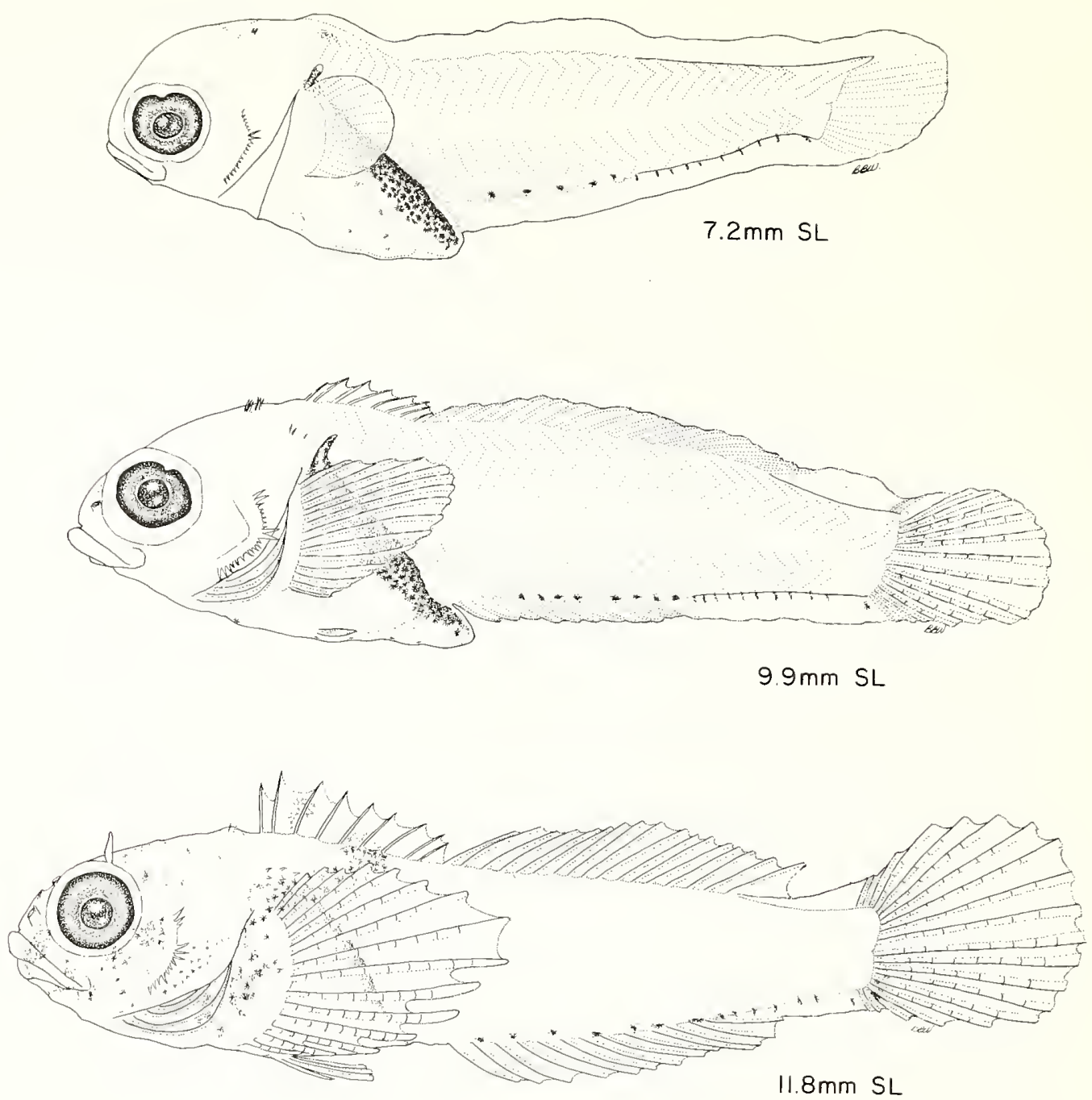

Figure 4.-Larvae of Artedius Type 2.

Type 2 which he called Cottid 4, "Water Wings." Eldridge (1970) also described and illustrated $(3.2 \mathrm{~mm})$ similar appearing larvae with gut protrusions called Cottid No. 4. White (1977) illustrated (3.9 mm NL) and briefly described similar larvae as Cottid III with two "horn-like extensions protruding... from the gut." Young stages of two known species, $A$. lateralis and $A$. fenestralis, have been described which somewhat resemble our Artedius Type 2, although their similarity cannot be confirmed on the basis of the literature alone (see Discussion below). Budd (1940) illustrated and described eggs and larvae $(4.1 \mathrm{~mm} \mathrm{SL})$ of $A$. lateralis. Marliave
(1975) illustrated and briefly described young stages (4, $8,11,14 \mathrm{~mm}$ TL (total length)) of $A$. lateralis. He also discussed eggs of $A$. lateralis and eggs and larvae of $A$. fenestralis. Larvae of this form were called Artedius sp. 2 by Richardson (footnote 4) and Richardson and Pearcy (1977).

Distinguishing Features. Larvae of Artedius Type 2 probably hatch at around $3-4 \mathrm{~mm}$. The largest specimens we have captured pelagically are $\sim 14 \mathrm{~mm}$, taken in a neuston net $2 \mathrm{~km}$ off Newport, Oreg. They are beginning to develop juvenile pigmentation. 
In larvae, melanophores are concentrated over the dorsolateral surface of the gut. Nape pigment is usually present in larvae except at the smallest sizes but becomes embedded and obscured in later stages $>8 \mathrm{~mm}$. A row of usually $<20$ (often $15-20$ but $<25$ in larvae $<5$ $\mathrm{mm}$ ) melanophores occurs along the ventral body midline posterior to the anus. The number of ventral midline melanophores helps distinguish Artedius Type 2 from $A$. harringtoni which usually has $>20$. Approximately the posterior half of these melanophores extend as characteristic dashes of pigment onto the ventral finfold especially in larvae $>7 \mathrm{~mm}$. In the largest specimens, $\sim 12-14 \mathrm{~mm}$, pigment is added to the head region, at the base of the pectoral fin, to the anterior portion of the spinous dorsal fin, as a bar extending from the dorsal surface of the abdominal cavity near the dorsal origin of the pectoral fin to the middle of the spinous dorsal fin, and as groups of melanophores along the lateral midline from the gut region to the caudal fin.

As in A. harringtoni a series of small spines develops along the margin of the preopercle, beginning to appear $\sim 4.5-5.0 \mathrm{~mm}$. They increase in number to $\sim 20-25$ in postflexion larvae, $\sim 7-11 \mathrm{~mm}$, then decrease in the largest specimens. Those at the dorsal edge and at the posterior angle of the preopercle become large relative to the rest of the spines. Clusters of spines develop in the parietal region beginning with 1 or 2 spines in 6-7 $\mathrm{mm}$ larvae, 3 spines in 7.5-8.5 $\mathrm{mm}$ larvae, and more on larger specimens. By $\sim 9-9.5 \mathrm{~mm}$ clusters of spines occur in both the parietal and posttemporal regions, and these remain visible on the largest specimens examined. Such spine clusters are never obvious on $A$. harringtoni.

Larvae of Artedius Type 2 are similar in shape to $A$. harringtoni being stubby and often with a hump in the nape region. The hindgut appears to trail below the body. Snout to anus length is $<50 \%$ SL. A prominent feature is the presence of gut diverticula, one on each side, protruding laterally from the dorsal surface of the abdominal cavity immediately posterior to the pectoral fin. These gut diverticula, never observed in $A$. harringtoni, are most pronounced in small larvae, becoming less conspicuous as the pectoral fin develops. They are present on the largest pelagic specimens we examined. This larval character is probably lost during transformation to the juvenile stage. Body depth at the pectoral fin base ranges from about 19 to $29 \%$ SL. The length of the pectoral fin increases from 4 to $29 \%$ SL during larval development. Branchiostegal rays, which could be counted on specimens $>7 \mathrm{~mm}$, consistently numbered 6 for all larvae in this series compared to 7 for $A$. harringtoni. The adult complement of dorsal, anal, pectoral, and pelvic fin rays or ray elements is countable by $\sim 10$ $\mathrm{mm}$.

Discussion. Meristics on the largest specimens indicate they may be either A. fenestralis or A. lateralis, two of the three most abundant species of Artedius off Oregon, as previously noted. Dorsal soft ray counts of 16-18 $(16=6 ; 17=8,18=2)$ on larval specimens in our collections seem more indicative of $A$. fenestralis than $A$. lateralis which has 15-17 (Howe and Richardson footnote $3)$.

Head cirri patterns on the largest specimens indicate they could be $A$. fenestralis. The largest specimens of Artedius Type 2 have postocular cirri but show no sign of forming nasal cirri. Bolin (1944) reported that $A$. fenestralis has no nasal cirri while $A$. lateralis has 1 or 2 cirri at the base of each nasal spine. This would indicate Artedius Type 2 is A. fenestralis unless nasal cirri appear later in development. The largest specimens of $A$. harringtoni, similar in size to the largest specimens of Artedius Type 2, already have nasal cirri, indicating that the absence of nasal cirri in Type 2 is real.

In a brief description Marliave (1975) stated that “. . yolk sac larvae of Artedius fenestralis are identical to the same stage of $A$. lateralis except that they are perhaps a bit smaller. By the onset of fin ray formation A. fenestralis larvae have a patch of melanophores on the nape but none on the head, in contrast to $A$. lateralis . . [which] develops a patch of melanophores in the occipital region (none on the nape)." He further stated that A. lateralis larvae "develop lateral extensions ... over the gut" that "distend the body wall over the dorsal in. sertion of the pectorals." Presumably then both $A$. lateralis and $A$. fenestralis larvae have gut diverticula. [Budd (1940) did not show gut diverticula on larvae of $A$. lateralis, but his specimens may have been too small to bave developed them.] However, if the presence of nape pigment is a specific character for $A$. fenestralis as Marliave reported, then most, if not all, of our Artedius Type 2 may be $A$. fenestralis. That is if the other larval characters of $<20$ ventral midline melanophores, presence of gut diverticula, and a pronounced cluster of spines in the parietal region are adequate to distinguish Artedius Type 2 at the species level. Interestingly, larvae of this type occur off southern California (Ahlstrom ${ }^{7}$ ) beyond the southern range limit of Diablo Cove, Calif., reported for A. fenestralis (Miller and Lea 1972). However, A. lateralis does occur there. Final confirmation of our Type 2 awaits identification of larvae of all Artedius species reported to occur off Oregon.

If this series is $A$. fenestralis and we have also taken $A$. harringtoni, we would expect to have larvae of $A$. lateralis in our collections since adults of all three are relatively abundant in Oregon tidepools, as we have noted. Larvae of $A$. harringtoni and Artedius Type 2 were among the most abundant cottid larvae in our collections. Explanations for missing A. lateralis larvae could be several: 1) they are mixed in with one of our series, e.g., Artedius Type 2;2) they are one of our unidentified larval types and not as abundant in our collections; 3) they exhibit a different early life history strategy, e.g., they are more benthic or coastal in nature and thus would not be found in plankton collections taken $2 \mathrm{~km}$ or more offshore.

E. H. Ahlstrom, Senior Scientist, Southwest Fisheries Center, National Marine Fisheries Service, NOAA, P.O. Box 271, La Jolla, CA 92038, pers. commun. October 1978. 


\section{Clinocottus acuticeps (Gilbert)}

(Figures 5, 6; Tables 7, 8)

Literature. An $8.6 \mathrm{~mm}$ SL larva resembling Clinocottus acuticeps was illustrated and described by Blackburn (1973). He called his specimen Cottid 1 "Biramous anus," possibly Clinocottus sp. Eggs and larvae of two

Figure 5.-Larvae of Clinocottus acuticeps. The second figure from the top is a ventral view showing hindgut diverticula.

Clinocottus acuticeps
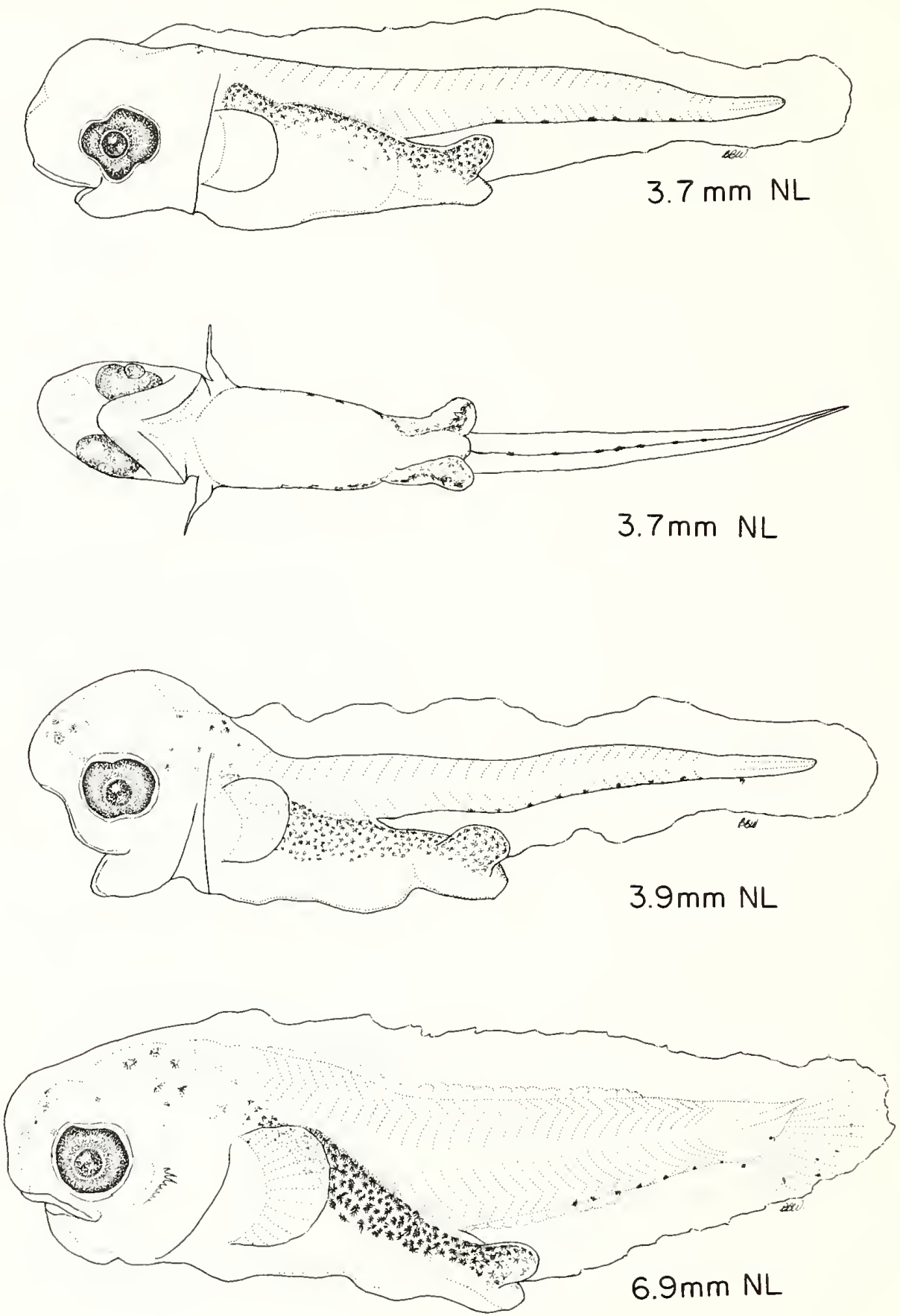


\section{Clinocottus acuticeps}
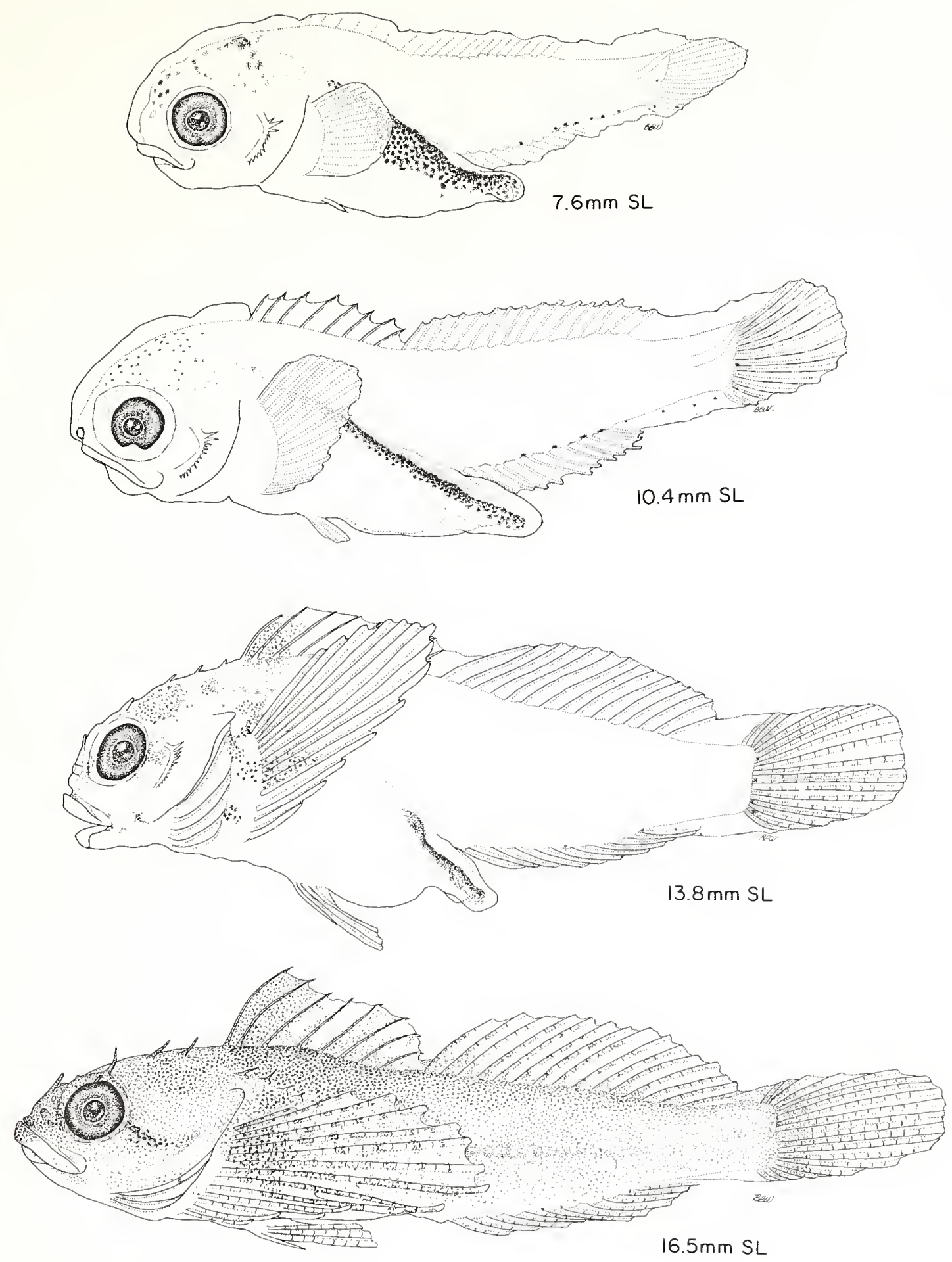

Figure 6.-Young of Clinocottus acuticeps. 
other species of Clinocottus from the northeast Pacific have been described, C. analis ([Eigenmann 1892 (as Oligocottus analis); Budd 1940] including illustrations of larvae and juveniles 4.6, 5.0, 7.6, 8.3, 9.9, 10.8, 18.0, and $24.3 \mathrm{~mm}$ TL. Larvae of $C$. acuticeps were called Cottidae sp. 12 by Richardson (footnote 4) and Richardson and Pearcy (1977).

Distinguishing Features. Larvae of C. acuticeps probably hatch at $\sim 3-4 \mathrm{~mm}$ and begin to transform to juveniles $\sim 13-14 \mathrm{~mm}$. A $16.5 \mathrm{~mm}$ specimen collected in a tidepool is fully transformed juvenile.

Pigment is moderately scattered over the dorsolateral surface of the gut. Nape pigment is present on all small larvae but becomes embedded in larger specimens. Pigment is also present on the head between the eyes in all but the smallest specimens which may be faded. Melanophores are added to the head region during development. A series of usually $<15$ ventral midline melanophores is present on the tail beginning at about a vertical through the anal opening in the trailing hindgut. No melanophores are on the ventral body margin anterior to that point. Melanophores in this ventral midline series are rather inconspicuous compared to other species. The posterior melanophores in this ventral row do not extend as dashes onto the finfold as in Artedius spp. but may actually occur on the ventral finfold rather than on the body margin in larger larvae. A single melanophore per- sists near the notochord tip, eventually appearing at the middle of the caudal fin base. A few streaks of pigment may be visible on the ventral finfold near the tail tip and later on the caudal fin. On larvae nearing transformation, pigment is added to the head, pectoral fin base, and onto the anterior end of the spinous dorsal fin. Recently transformed juveniles are heavily pigmented with a noticeably darkened area at the anterior end of the first dorsal fin as in adults.

A series of $\sim 10-15$ small spines develops on the preopercular margin. These begin to appear at $\sim 6-7 \mathrm{~mm}$. With development, the upper spines become the most prominent. The number of preopercular spines decreases during transformation with only 1 dorsal spine visible in a $19.4 \mathrm{~mm}$ stained juvenile. No additional head spines are obvious in larvae. Parietal and nuchal spines are never apparent although the flabby skin could possibly obscure their presence on unstained larvae.

Larvae of $C$. acuticeps have an unusual gut, the posterior portion of which trails well below the body. Near the anus two diverticula or protrusions are evident throughout the larval period, but they are no longer visible on transformed juveniles. Snout to anus length is relatively long for cottid larvae, ranging from $\sim 62$ to $71 \%$ SL during the larval period. The larvae have a rather flabby appearance at times seeming to be encased in a bubble of loose outer skin, particularly in the head region. Body depth ranges from $\sim 22$ to $33 \%$ SL during larval develop-

Table 7.-Meristics from young of Clinocottus acuticeps. (Specimen between dashed line is undergoing notochord flexion.) $\left[^{*}=\right.$ Specimens stained with Alizarin Red $\mathrm{S} ;{ }^{* *}=$ Dorsal fin spines and soft rays cannot be distinguished; $\mathrm{B}=\mathrm{Bases}$ only; $\mathrm{D}=$ Damaged; $\mathrm{N}=$ Not examined.]

\begin{tabular}{|c|c|c|c|c|c|c|c|c|c|c|c|c|c|c|c|}
\hline \multirow{4}{*}{$\begin{array}{l}\text { Body } \\
\text { length }\end{array}$} & & & \multirow{4}{*}{$\begin{array}{l}\text { Anal } \\
\text { fin } \\
\text { rays }\end{array}$} & \multirow{3}{*}{\multicolumn{2}{|c|}{$\begin{array}{c}\text { Pectoral } \\
\text { fin rays }\end{array}$}} & \multirow{4}{*}{$\begin{array}{l}\text { Pelvic } \\
\text { fin } \\
\text { spine } \\
\text { \& rays }\end{array}$} & \multirow{4}{*}{$\begin{array}{l}\text { Preoper- } \\
\text { cular } \\
\text { spines }\end{array}$} & \multirow{4}{*}{$\begin{array}{l}\text { Ventral } \\
\text { midline } \\
\text { melano- } \\
\text { phores }\end{array}$} & \multicolumn{4}{|c|}{ Caudal fin rays } & \multirow{2}{*}{\multicolumn{2}{|c|}{ Vertebrae }} & \multirow{4}{*}{$\begin{array}{c}\text { Branchi- } \\
\text { ostegal } \\
\text { rays }\end{array}$} \\
\hline & \multirow{2}{*}{\multicolumn{2}{|c|}{ Dorsal fin }} & & & & & & & \multicolumn{2}{|c|}{ Dorsal } & \multicolumn{2}{|c|}{ Ventral } & & & \\
\hline & & & & & & & & & Second- & Prin- & Prin. & Second- & \multirow{2}{*}{$\begin{array}{l}\text { Abdom- } \\
\text { inal }\end{array}$} & \multirow{2}{*}{$\begin{array}{c}\text { Cau- } \\
\text { dal }\end{array}$} & \\
\hline & Spines & Rays & & Left & Right & & & & ary & cipal & cipal & ary & & & \\
\hline 3.7 & - & - & - & - & $\mathrm{N}$ & - & - & 7 & $\mathrm{~N}$ & $\mathrm{~N}$ & $\mathrm{~N}$ & $\mathrm{~N}$ & $\mathrm{~N}$ & $\mathrm{~N}$ & $\mathrm{~N}$ \\
\hline 3.9 & - & - & - & - & $\mathrm{N}$ & - & - & 9 & $\mathrm{~N}$ & $N$ & $\mathrm{~N}$ & $\mathrm{~N}$ & $\mathrm{~N}$ & $\mathrm{~N}$ & $N$ \\
\hline & & & & & & 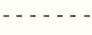 & & & & & & & & & $-\cdots$ \\
\hline 6.9 & \multicolumn{2}{|c|}{$-22 \mathrm{~B}-* *$} & $11 \mathrm{~B}$ & 14 & $\mathrm{~N}$ & - & 11 & 8 & $\mathrm{~N}$ & N & $\mathrm{N}$ & $\mathrm{N}$ & $\mathrm{N}$ & $\mathrm{N}$ & $N$ \\
\hline \multicolumn{16}{|c|}{ - } \\
\hline 7.6 & VII & 15 & 11 & 14 & $\mathrm{~N}$ & Buds & 11 & 7 & $\mathrm{~N}$ & N & $\mathrm{N}$ & $\mathrm{N}$ & $\mathrm{N}$ & $\mathrm{N}$ & $\mathrm{N}$ \\
\hline $10.2^{*}$ & VIII & 15 & 12 & 14 & 14 & $\mathbf{1}, 3$ & 11 & $\mathrm{~N}$ & 4 & 6 & 5 & 2 & 10 & 14 & 6 \\
\hline 10.4 & VIII & 16 & 12 & 14 & $\mathrm{~N}$ & 1,3 & 13 & 7 & $\mathrm{~N}$ & $\mathrm{~N}$ & $\mathrm{~N}$ & $\mathrm{~N}$ & $\mathrm{~N}$ & $\mathrm{~N}$ & $\mathrm{~N}$ \\
\hline 13.8 & IX & 15 & 11 & 14 & $\mathrm{~N}$ & 1,3 & 11 & 4 & $\mathrm{~N}$ & $\mathrm{~N}$ & $\mathrm{~N}$ & $\mathrm{~N}$ & $\mathrm{~N}$ & $\mathrm{~N}$ & $N$ \\
\hline $14.2^{*}$ & IX & 16 & 13 & 14 & 14 & 1,3 & 12 & $\mathrm{~N}$ & 7 & 6 & 5 & 5 & 10 & 22 & 6 \\
\hline $19.4^{*}$ & D & D & 12 & 14 & 14 & 1,3 & 1 & $\mathrm{~N}$ & D & D & $\mathrm{D}$ & D & 10 & 23 & 6 \\
\hline
\end{tabular}

Table 8.-Measurements $(\mathrm{mm})$ of larvae of Clinocottus acuticeps. (Specimen between dashed line is undergoing notochord flexion.)

\begin{tabular}{|c|c|c|c|c|c|c|c|c|}
\hline $\begin{array}{l}\text { Body } \\
\text { length }\end{array}$ & $\begin{array}{l}\text { Head } \\
\text { length }\end{array}$ & $\begin{array}{l}\text { Snout } \\
\text { length }\end{array}$ & $\begin{array}{c}\text { Eye } \\
\text { diameter }\end{array}$ & $\begin{array}{l}\text { Snout to } \\
\text { anus length }\end{array}$ & $\begin{array}{l}\text { Body depth } \\
\text { at pectoral } \\
\text { fin base }\end{array}$ & $\begin{array}{l}\text { Pectoral } \\
\text { fin length }\end{array}$ & $\begin{array}{l}\text { 2d preoper- } \\
\text { cular } \\
\text { spine length }\end{array}$ & $\begin{array}{c}\text { Parietal } \\
\text { spine length }\end{array}$ \\
\hline 3.7 & 0.90 & 0.14 & 0.38 & 2.3 & 0.90 & 0.26 & $\mathrm{~N}^{2}$ & - \\
\hline 3.9 & 0.88 & 0.16 & 0.38 & 2.4 & 0.86 & 0.40 & $\mathrm{~N}$ & - \\
\hline \\
\hline 6.9 & 2.0 & 0.39 & 0.62 & 4.6 & 2.1 & 0.82 & $\mathrm{~N}$ & - \\
\hline \multicolumn{9}{|c|}{ 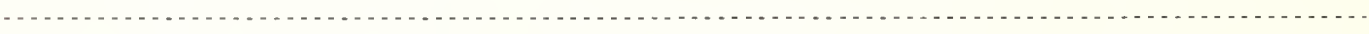 } \\
\hline 7.6 & 2.3 & 0.47 & 0.70 & 5.4 & 2.5 & 1.2 & $\mathrm{~N}$ & - \\
\hline 10.4 & 2.9 & 0.58 & 0.94 & 7.0 & 2.6 & 1.6 & $\mathrm{~N}$ & - \\
\hline 13.8 & 4.2 & 0.86 & 1.2 & 9.0 & 4.2 & 4.1 & $\mathrm{~N}$ & - \\
\hline
\end{tabular}


ment. The adult complement of fin rays (or elements) can be counted in larvae by $\sim 7-8 \mathrm{~mm}$. Late stage larvae have relatively long pectoral fins, $\sim 30 \%$ SL. On larger larvae, $\sim 13-14 \mathrm{~mm}$, the inner pelvic fin ray is noticeably attached to the belly by a membrane. This diagnostic character helped link the larval series to identified juveniles.

Discussion. Larvae of C. acuticeps are similar to described larvae of $C$. analis and $C$. recalvus in size at hatching, $\sim 3-4 \mathrm{~mm}$, and presence of nape and head pigment and pigment over the gut on small larvae. (The lack of head pigment on the smallest larvae of $C$. acuticeps may have been caused by fading.) All three species have a series of ventral midline melanophores but those on $C$. analis and $C$. recalvus appear to be higher in number than $C$. acuticeps. The posterior melanophores in this series do not appear to extend out onto the finfold in $C$. acuticeps as reported for the other two species. Based on the illustrations, small larvae of $C$. analis and C. recalvus have a much shorter relative snout to anus length than $C$. acuticeps. Large larvae of $C$. recalvus develop multiple spines on the preopercle as do $C$. acuticeps, but they apparently do not develop the hindgut diverticula or the flabby appearance of $C$. acuticeps. These marked differences in body form, mainly the gut length and hindgut protrusions of $C$. acuticeps could lead to questions about the relationships within the genus Clinocottus, particularly as larvae of more species become known.

\section{Cottidae Type 1}

(Figure 7; Tables 9, 10)

Literature. Larvae of this type have not been previously described. These larvae were called Cottidae sp. 1C by Richardson (footnote 4) and Richardson and Pearcy (1977).

Distinguishing Features. The smallest larvae in our collections are $\sim 4 \mathrm{~mm}$. They are relatively undeveloped and probably recently hatched. Our largest specimens are $\sim 9$ $\mathrm{mm}$. They have visible fin ray elements but fins are not completely developed. Transformation occurs at some larger size.

The larvae are relatively unpigmented. Melanophores occur at the nape, in a rather light scattering over the dorsolateral gut surface and in a row of $<10$ along the ventral midline posterior to the anus. These ventral midline melanophores are well spaced beginning $\sim 4-5$ myomeres behind the anus and extending to the posteriormost myomere. They decrease in number anteriorly with development.

The preopercle develops a high number, $\sim 19$, of small spines on its margin. A cluster of tiny spines develops in the parietal region, a few of which are visible on $4 \mathrm{~mm}$ specimens. Another cluster of minute spines develops in the posttemporal-supracleithral region on larger specimens.

The larvae are rather stubby in shape. The hindgut trails below the body. Snout to anus length is $\sim 40-50 \%$ SL. Body depth at pectoral base is $\sim 23-26 \%$ SL. The snout is relatively round in appearance.

Discussion. Specific or generic identification of Cottidae Type 1 is not possible without additional material. These larvae are related to the Artedius-Clinocottus-Oligottus group of cottids based on counts of the largest specimen and the presence of multiple spines on the preopercle. Based on larval characters, these larvae appear to most closely resemble Artedius spp. The clusters of spines in the parietal and posttemporal-supracleithral region in these larvae have been observed only in Artedius Type 2 and Cottidae Type 3. They do not occur in C. acuticeps, C. recalvus (Morris 1951), or O. maculosus (Stein 1972, 1973) the latter of which reportedly develops only 2 spines in the parietal region. Spines on the preopercle of the largest specimen of Type 1 appear to be enlarging somewhat dorsally and at the posterior angle as in A. harringtoni and Artedius Type 2. However, their development would have to be traced in

Table 9.-Meristics of larvae of Cottidae Type 1. (Specimen between dashed lines is undergoing notochord flexion.)

\begin{tabular}{|c|c|c|c|c|c|c|c|c|}
\hline Body & $\begin{array}{c}\text { Dorsal } \\
\text { fin }\end{array}$ & $\begin{array}{l}\text { Dorsal } \\
\text { fin }\end{array}$ & $\begin{array}{c}\text { Anal } \\
\text { fin }\end{array}$ & $\begin{array}{r}\mathrm{Pe} \\
\text { fin } \\
\end{array}$ & $\begin{array}{l}\text { toral } \\
\text { rays }\end{array}$ & $\begin{array}{l}\text { Pelvic fin } \\
\text { spine }\end{array}$ & $\begin{array}{l}\text { Preoper- } \\
\text { cular }\end{array}$ & $\begin{array}{l}\text { Ventral } \\
\text { midline } \\
\text { melano }\end{array}$ \\
\hline length & spines & rays & rays & Left & Right & and rays & spines & phores \\
\hline 4.2 & - & - & - & - & $\mathrm{N}^{1}$ & - & - & 7 \\
\hline 6.7 & - & - & - & - & $\mathrm{N}$ & - & 19 & 7 \\
\hline 9.0 & IX & 18 & 12 & 15 & $\mathrm{~N}$ & Buds & 19 & 3 \\
\hline
\end{tabular}

Table 10.-Measurements ( $\mathrm{mm}$ ) of larvae of Cottidae Type 1. (Specimen between dashed lines is undergoing notochord flexion.)

\begin{tabular}{|c|c|c|c|c|c|c|c|c|}
\hline $\begin{array}{l}\text { Body } \\
\text { length }\end{array}$ & $\begin{array}{r}\text { Head } \\
\text { length }\end{array}$ & $\begin{array}{l}\text { Snout } \\
\text { length }\end{array}$ & $\begin{array}{c}\text { Eye } \\
\text { diameter }\end{array}$ & $\begin{array}{c}\text { Snout to } \\
\text { anus length }\end{array}$ & $\begin{array}{l}\text { Body depth } \\
\text { at pectoral } \\
\text { fin base }\end{array}$ & $\begin{array}{l}\text { Pectoral } \\
\text { fin length }\end{array}$ & $\begin{array}{l}\text { 2d preoper- } \\
\text { cular } \\
\text { spine length }^{1}\end{array}$ & $\begin{array}{c}\text { Parietal } \\
\text { spine length }^{2}\end{array}$ \\
\hline 4.2 & 0.84 & 0.20 & 0.42 & 1.8 & 0.98 & 0.20 & $\mathrm{~N}^{3}$ & $\mathrm{~N}$ \\
\hline \\
\hline 6.7 & 1.4 & 0.20 & 0.52 & 2.6 & 1.6 & 0.55 & $\mathrm{~N}$ & $\mathrm{~N}$ \\
\hline \multicolumn{9}{|c|}{$\begin{array}{l}- \\
-\end{array}$} \\
\hline 9.0 & 2.1 & 0.25 & 0.94 & 4.2 & 2.5 & 1.2 & $\mathrm{~N}$ & $\mathrm{~N}$ \\
\hline
\end{tabular}

${ }^{1}$ Multiple spines develop along preopercular margin instead of usual 4.

${ }^{2}$ Multiple spines develop in region of parietal spine.

${ }^{3} \mathrm{~N}=$ Not measured. 

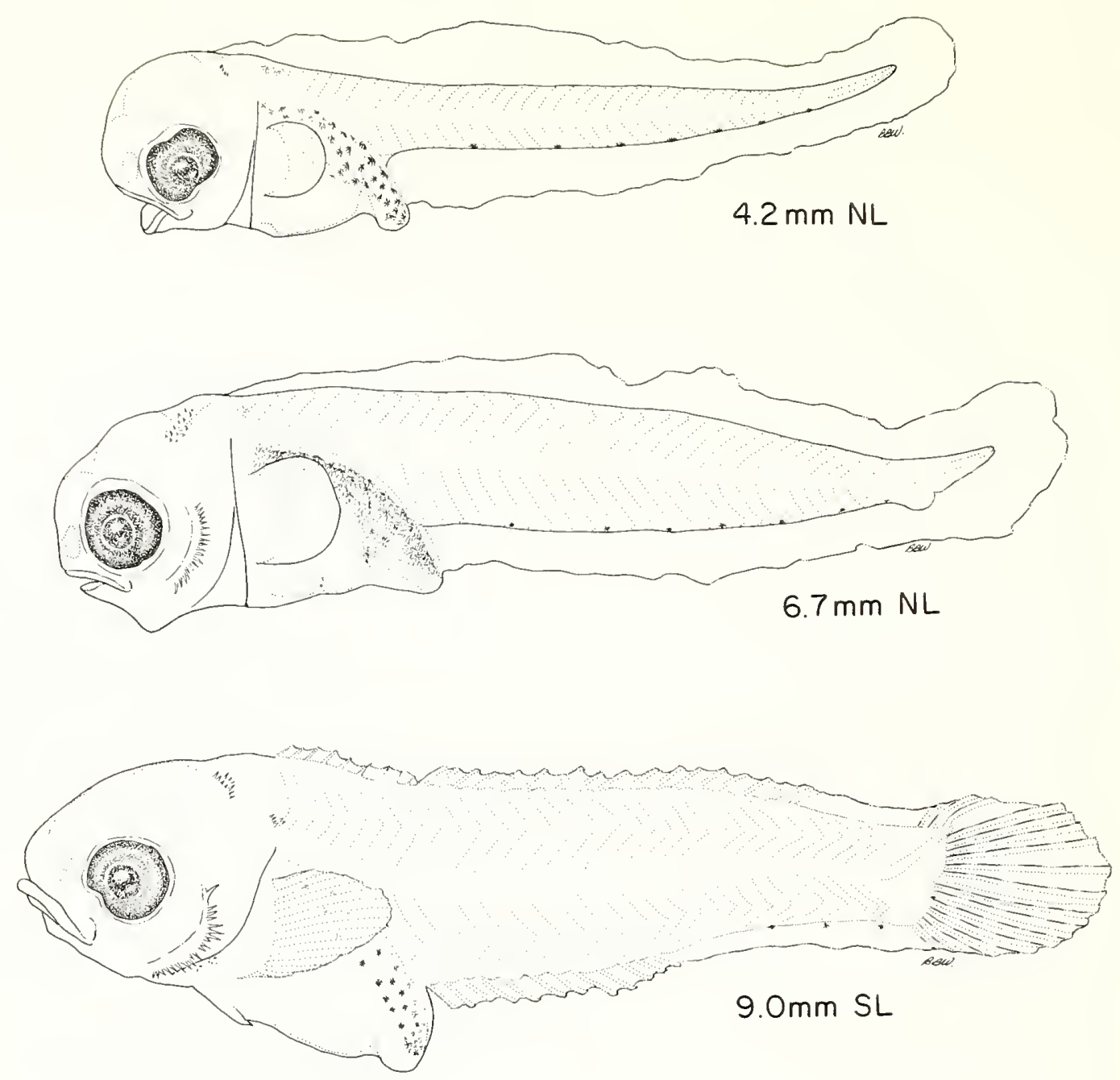

Figure 7.-Larvae of Cottidae Type 1.

larger specimens to determine positively if the pattern is the same as in our two Artedius types. This preopercular spine pattern differs from that in $C$. acuticeps and $C$. recalvus (Morris 1951) in which the dorsalmost spine becomes the largest. The number of preopercular spines in Type 1 is relatively high, $\sim 19$ as in A. harringtoni and Artedius Type $2(>20)$, compared with the lower numbers for C. acuticeps (10-15), C. recalvus (4-9), and O. maculosus (7-9). The gut shape and length resemble our Artedius types.

Based on the meristic compilation by Howe and Richardson (footnote 3) (Table 1), counts on our largest Cottidae Type 1 specimen, particularly the 18 dorsal soft rays, agree with only four species: $A$. fenestralis, A. harringtoni, $O$. maculosus, and $O$. snyderi. The larvae are not $A$. harringtoni based on our description and they are not $O$. maculosus based on the description by Stein (1972, 1973). Identification as $O$. snyderi is not possible based on Stein's (1972) description although it seems unlikely that our larvae are this species. Larvae of $O$. maculosus have a very different preopercular spine pat-

tern from our Type 1, and one would expect a pattern similar to O. maculosus on O. snyderi. Problems in identifying $A$. fenestralis were discussed under Artedius Type 2 and cannot be resolved at this time. 


\section{Cottidae Type 2}

(Figure 8; Tables 11, 12)

Literature. Larvae of this type have not been previously described. These larvae were called Cottidae sp. 20 by Richardson (footnote 4) and Richardson and Pearcy (1977).

Distinguishing Features. The smallest larvae in the series are $\sim 4 \mathrm{~mm}$ and recentl: hatched. The largest specimen is $7.4 \mathrm{~mm}$ in which tha bases of dorsal and anal

\section{Cottidae Type 2}
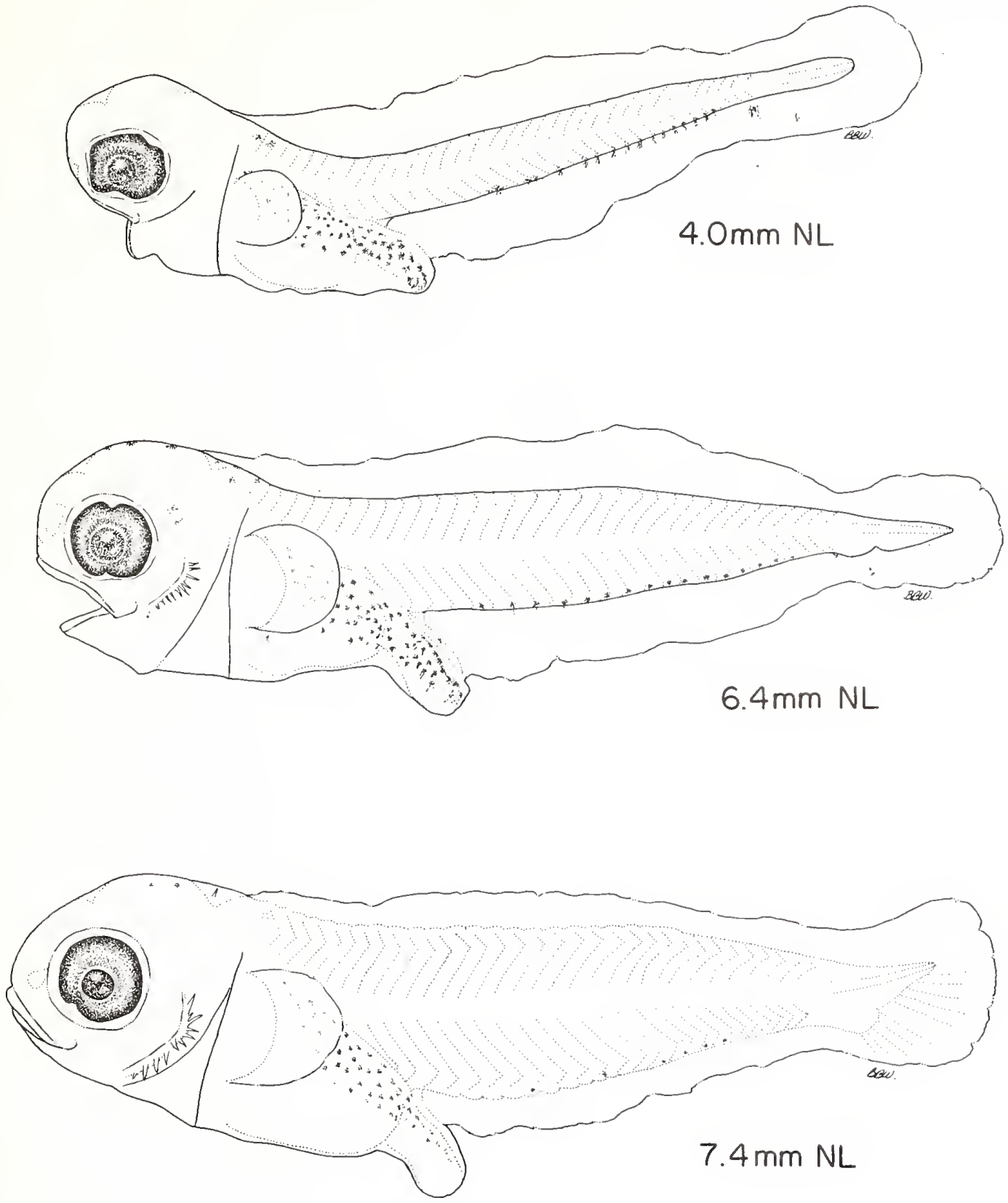

Figure 8.-Larvae of Cottidae Type 2. 
fin rays are just forming. Size at transformation is unknown.

Preflexion larvae have pigment at the nape, a relatively light scattering of melanophores over the dorsolateral surface of the gut and a series of $<20$ but $>10$ ventral midline melanophores posterior to the anus. This rentral series begins near or several myomeres posterior to a vertical through the anal opening and extends to about the fourth from last myomere. Some melanophores in this series radiate out onto the finfold. A few melanophores occur on the finfold near the tail tip. With development some melanophores are added to the head and the number of ventral midline melanophores decreases. Melanophores were not apparent on the caudal fin base of the largest specimen, as would be expected based on the pigmentation near the tail tip of smaller larvae, but the specimen was badly faded.

A series of approximately 10 small spines develop on the preopercular margin. The upper spine appears somewhat thicker than the lower spines on the largest specimen. A tiny parietal spine is visible on the $7.4 \mathrm{~mm}$ specimen but no additional head region spines are apparent.

The shape of the gut is rather distinctive with the hindgut trailing noticeably below the body, similar to Clinocottus acuticeps. Snout to anus length is around $50 \% \mathrm{SL}$, longer than most species. When viewed ventrally, the wall of the hindgut bulges out on each side of the anus reminiscent of the hindgut diverticula of $C$. acuticeps but not as pronounced. Body depth at the pectoral fin base is $\sim 21-27 \% \mathrm{SL}$. The snout is quite rounded. The larvae have a flabby appearance, particularly around the head region, similar to $C$. acuticeps.

Discussion. The multiple preopercular spine pattern of Cottidae Type 2 indicates this type is related to the Artedius-Clinocottus-Oligocottus group. Based on a combination of larval characters it seems to resemble

Table 11.-Meristics from larvae of Cottidae Type 2. (Specimens below dashed line are undergoing notochord flexion.)

\begin{tabular}{|c|c|c|c|c|c|c|c|c|}
\hline $\begin{array}{l}\text { Body } \\
\text { length }\end{array}$ & $\begin{array}{c}\text { Dorsal } \\
\text { fin } \\
\text { spines }\end{array}$ & $\begin{array}{c}\text { Dorsal } \\
\text { fin } \\
\text { rays } \\
\end{array}$ & $\begin{array}{c}\text { Anal } \\
\text { fin } \\
\text { rays }\end{array}$ & $\begin{array}{r}\text { Pec } \\
\text { fin } \\
\text { Left } \\
\end{array}$ & $\begin{array}{l}\text { toral } \\
\text { rays } \\
\text { Right }\end{array}$ & $\begin{array}{c}\text { Pelvic fin } \\
\text { spine } \\
\text { and rays }\end{array}$ & $\begin{array}{c}\text { Preoper- } \\
\text { cular } \\
\text { spines }\end{array}$ & $\begin{array}{c}\text { Ventral } \\
\text { midline } \\
\text { melano- } \\
\text { phores }\end{array}$ \\
\hline 4.0 & - & - & - & - & - & - & - & 15 \\
\hline 6 & - & - & - & - & - & - & 10 & 17 \\
\hline 7.4 & - & - & - & - & - & - & 11 & 6 \\
\hline
\end{tabular}

Clinocottus most closely. It has a relatively low number $(<15)$ of multiple spines on the preopercle as does $C$. acuticeps (10-15) and C. recalvus (5-9) (Morris 1951). The upper preopercular spine appears to be enlarging relative to the rest, as in $C$. acuticeps and $C$. recalvus. Only a tiny parietal spine is visible on the largest specimen. Two tiny spines appear in the parietal and nuchal positions in $C$. recalvus but only for a brief period, and none were observed in C. acuticeps, possibly obscured by the flabby skin. Melanophores appear on the nape and head of all $C$. recalvus and all but the smallest C. acuticeps and Cottidae Type 2. The lack of pigment on the head of our smallest specimens could be a result of fading. Clinocottus recalvus larvae were described from reared and freshly preserved material which often tends to have increased numbers of and more pronounced melanophores. The hindgut trails well below the body as in C. acuticeps. Bulges appear in the hindgut wall on each side of the anus similar to the more pronounced diverticula of $C$. acuticeps. Such protuberances were not noted for $C$. recalvus, perhaps on observational oversight. Some melanophores in the ventral midline series radiate onto the finfold as in $C$. recalvus. This quality was not noted in $C$. acuticeps but possibly could be related to quality of preservation. Melanophores occur on the finfold near the tail tip, often as streaks of pigment in all three forms. These melanophores later appear on the caudal fin in $C$. acuticeps and $C$. recalvus. They were not visible on our largest Cottidae Type 2 specimen possibly because it was faded.

\section{Cottidae Type 3}

(Figure 9; Tables 13, 14)

Literature. Larvae of this type have not been previously described. They were listed by Richardson (footnote 4) and Richardson and Pearcy (1977) as Oligocottus sp. 1.

Distinguishing Features. The smallest larvae we have taken are $\sim 5 \mathrm{~mm}$ and relatively undeveloped. Our largest specimen is $12.5 \mathrm{~mm}$. Most fins appear fully formed except for secondary caudal rays, but final transformation must occur at a somewhat larger size.

These larvae have intense pigment over the head and nape even in the smallest specimens. The head pigment is more pronounced than in any of our other lightly

Table 12.-Measurements (mm) of larvae of Cottidae Type 2. (Specimens below dashed line are undergoing notochord

\begin{tabular}{|c|c|c|c|c|c|c|c|c|}
\hline $\begin{array}{l}\text { Body } \\
\text { length }\end{array}$ & $\begin{array}{l}\text { Head } \\
\text { length }\end{array}$ & $\begin{array}{l}\text { Snout } \\
\text { length }\end{array}$ & $\begin{array}{c}\text { Eye } \\
\text { diameter }\end{array}$ & $\begin{array}{l}\text { Snout to } \\
\text { anus length }\end{array}$ & $\begin{array}{l}\text { Body depth } \\
\text { at pectoral } \\
\text { fin base }\end{array}$ & $\begin{array}{l}\text { Pectoral } \\
\text { fin length }\end{array}$ & $\begin{array}{l}\text { 2d preoper- } \\
\text { cular } \\
\text { spine length }\end{array}$ & $\begin{array}{c}\text { Parietal } \\
\text { spine length }\end{array}$ \\
\hline 4.0 & 0.8 & 0.16 & 0.42 & 2.2 & 0.84 & 0.24 & $\mathrm{~N}^{2}$ & - \\
\hline 6.4 & 1.5 & 0.27 & 0.55 & 3.0 & 1.6 & 0.27 & $\mathrm{~N}$ & - \\
\hline 7.4 & 1.8 & 0.55 & 0.66 & 3.9 & 2.0 & 0.66 & $\mathrm{~N}$ & 0.10 \\
\hline
\end{tabular}

${ }^{1}$ Multiple spines develop along preopercular margin instead of usual 4.

${ }^{2} \mathrm{~N}=$ Not measured. 


\section{Cottidae Type 3}
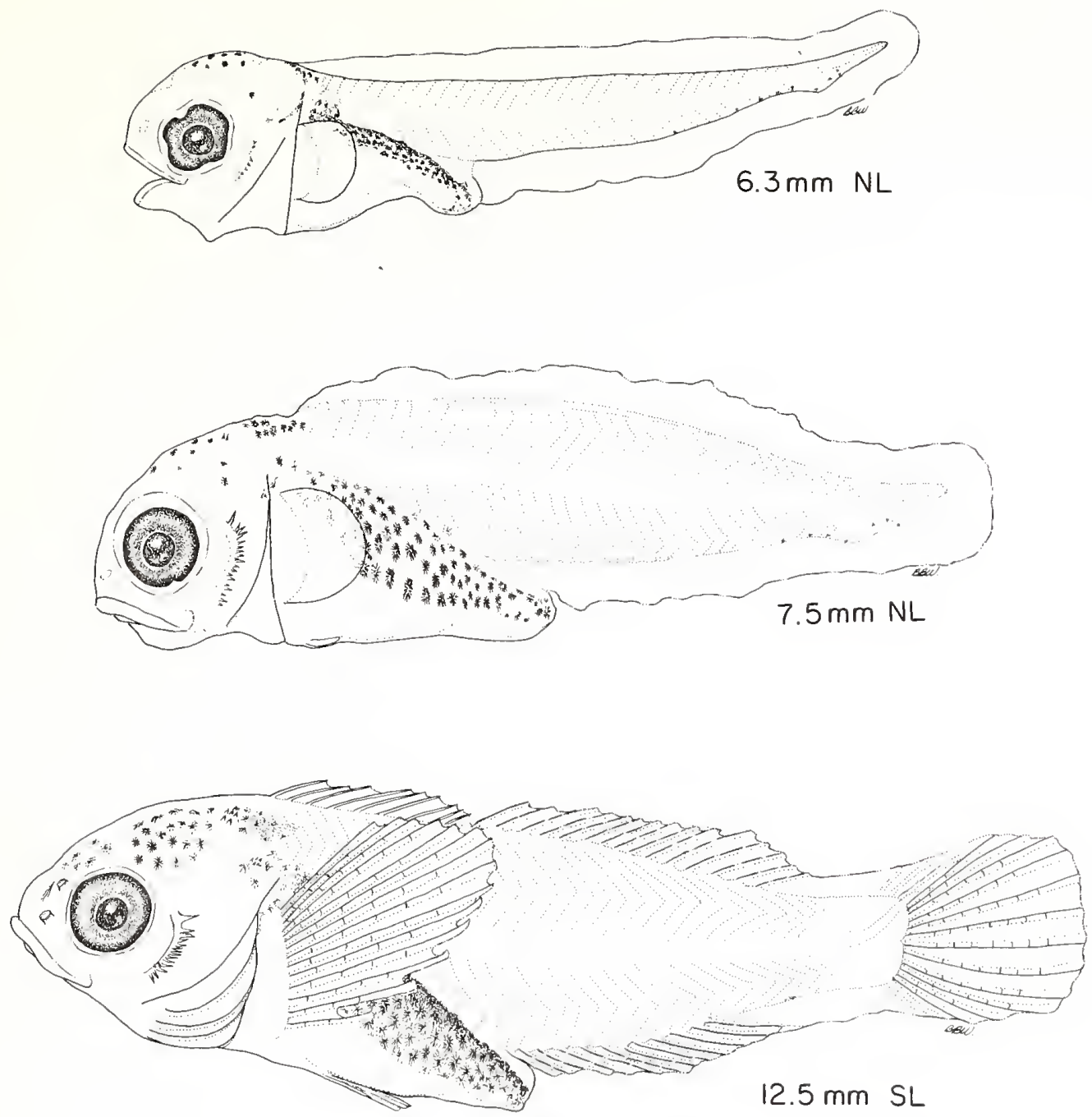

Figure 9.-Larvae of Cottidae Type 3.

pigmented forms, i.e., those with minimal body pigment. Pigment over the dorsolateral surface of the gut is also intense and densely concentrated, appearing as large round melanophores. The only other pigment consists of $\sim 4-5$ ventral midline melanophores near the posteriormost myomeres and a few at the base of the forming caudal fin.

The preopercle develops a series of multiple spines numbering $\sim 15-20$. The upper spine is the largest in the $12.5 \mathrm{~mm}$ specimen. A cluster of spines develops in the parietal region, appearing as a double row. A similar cluster develops in the posttemporal-supracleithral region. A nasal spine is also apparent in the $12.5 \mathrm{~mm}$ larva.

The hindgut is somewhat trailing and snout to anus length is $\sim 48-58 \% \mathrm{SL}$. The hindgut bulges slightly on either side of the anus although this is not nearly as pronounced as in Clinocottus acuticeps or Cottidae Type 2. Body depth at the pectoral fin base is $\sim 22-29 \% \mathrm{SL}$. The snout remains relatively rounded.

Discussion. Additional larger specimens are needed before identification of Cottidae Type 3 can be accomplished with certainty. Based on current knowledge 
of larval characters, particularly the multiple preopercular spine pattern, it belongs with the Artedius-Clinocottus-Oligocottus group. The number of preopercular spines is generally less than for A. harringtoni and Artedius Type 2 which have $>20$, and greater than for $C$. acuticeps, C. recalvus, and $O$. maculosus which all have $<15$ (Morris 1951; Stein 1973). The upper spine in Cottidae Type 3 becomes the largest as in Clinocottus and unlike Artedius. A cluster of spines develops in the parietal region similar to Artedius Type 2 and Cottidae
Table 13.-Meristics from larvae of Cottidae Type 3. (Specimens above dashed line are undergoing notochord flexion.)

\begin{tabular}{|c|c|c|c|c|c|c|c|c|}
\hline $\begin{array}{l}\text { Body } \\
\text { length }\end{array}$ & $\begin{array}{l}\text { Dorsal } \\
\text { fin } \\
\text { spines }\end{array}$ & $\begin{array}{c}\text { Dorsal } \\
\text { fin } \\
\text { rays }\end{array}$ & $\begin{array}{l}\text { Anal } \\
\text { fin } \\
\text { rays }\end{array}$ & $\begin{array}{r}\text { Pec } \\
\text { fin } \\
\text { Left }\end{array}$ & $\begin{array}{l}\text { toral } \\
\text { rays } \\
\text { Right }\end{array}$ & $\begin{array}{l}\text { Pelvic fin } \\
\text { spine } \\
\text { and rays }\end{array}$ & $\begin{array}{l}\text { Preoper- } \\
\text { cular } \\
\text { spines }\end{array}$ & $\begin{array}{l}\text { Ventral } \\
\text { midline } \\
\text { melano- } \\
\text { phores }\end{array}$ \\
\hline 6.3 & - & - & - & - & - & - & 7 & 5 \\
\hline 7.5 & - & - & - & - & - & - & 19 & 4 \\
\hline 12.5 & IX & 15 & 12 & 14 & 14 & I, 3 & 16 & 1 \\
\hline
\end{tabular}

Table 14.-Measurements $(\mathrm{mm})$ of larvae of Cottidae Type 3. (Specimens above dashed line are undergoing notochord flexion.)

\begin{tabular}{ccccccccc}
\hline $\begin{array}{c}\text { Body } \\
\text { length }\end{array}$ & $\begin{array}{c}\text { Head } \\
\text { length }\end{array}$ & $\begin{array}{c}\text { Snout } \\
\text { length }\end{array}$ & $\begin{array}{c}\text { Eye } \\
\text { diameter }\end{array}$ & $\begin{array}{c}\text { Snout to } \\
\text { anus length }\end{array}$ & $\begin{array}{c}\text { Body depth } \\
\text { at pectoral } \\
\text { fin base }\end{array}$ & $\begin{array}{c}\text { Pectoral } \\
\text { fin length }\end{array}$ & $\begin{array}{c}\text { 2d preoper- } \\
\text { cular } \\
\text { spine length }\end{array}$ & $\begin{array}{c}\text { Parietal } \\
\text { spine length }^{2}\end{array}$ \\
\hline 6.3 & 1.4 & 0.31 & 0.62 & 3.0 & 1.4 & 0.27 & $\mathrm{~N}^{3}$ & $\mathrm{~N}$ \\
7.5 & 1.9 & 0.58 & 0.74 & 4.2 & 2.2 & 0.56 & $\mathrm{~N}$ & $\mathrm{~N}$ \\
\hline 12.5 & 3.4 & 0.80 & 1.1 & 7.3 & 3.4 & 2.9 & $\mathrm{~N}$ & $\mathrm{~N}$ \\
\hline
\end{tabular}

${ }^{1}$ Multiple spines develop along preopercular margin instead of usual 4.

${ }^{2}$ Multiple spines develop in region of parietal spine.

${ }^{3} \mathrm{~N}=$ Not measured.

Type 1 and unlike C. acuticeps, C. recalvus, and $O$. maculosus. However, spines in the parietal cluster appear to be fewer in number $(\sim 5)$ and occur in two rows in contrast to Artedius Type 2 and Cottidae Type 1. A cluster of $\sim 4-5$ spines also develops in the posttemporalsupracleithral region somewhat like Artedius Type 2 and Cottidae Type 1 . The hindgut bulges slightly around the anus similar to but much less pronounced than in $C$. acuticeps and Cottidae Type 2. The hindgut trails more than in Artedius but less than in C. acuticeps and Cottidae Type 2 . Cottidae Type 3 has fewer ventral midline melanophores than Artedius or Clinocottus, and these appear only along the posterior portion of the tail as reported for O. snyderi (Stein 1972).

Meristics of the largest Type 3 specimen fit a number of species of Artedius and Clinocottus as well as Oligocottus maculosus (Table 1). Our specimens differ from larvae of the latter species described by Stein (1972, 1973) in having 1) $\sim 19$ preopercular spines instead of 7-9, 2) multiple spines in the parietal region instead of 2 , and 3 ) only 4-5 ventral midline melanophores instead of 11 20. Thus they must be either an Artedius or a Clinocottus species.

\section{Triglops sp.}

(Figure 10; Tables 15, 16)

Literature. Larvae identified as Triglops sp., which resemble our larvae, were illustrated $(8.3,12 \mathrm{~mm} \mathrm{SL})$ by Blackburn (1973) but no descriptive information was given. Larvae of other species of Triglops which have been described include 10-18 mm $T$. pingeli (Ehrenbaum 1905-1909; Koefoed 1907 [cited by Khan 1972]; Rass 1949) from the Atlantic Ocean and Barents Sea and 8.4, 11.6, 18.9, $23.4 \mathrm{~mm}$ TL $T$. murrayi (Khan 1972) from the Atlantic Ocean.

Distinguishing Features. Our smallest preflexion larva is $6.9 \mathrm{~mm}$ and relatively undeveloped. The largest

Table 15.-Meristics from larvae of Triglops sp. (Specimens above dashed line are preflexion, that below is postflexion.)

\begin{tabular}{|c|c|c|c|c|c|c|c|c|}
\hline \multirow{2}{*}{$\begin{array}{l}\text { Body } \\
\text { length }\end{array}$} & \multirow{2}{*}{$\begin{array}{l}\text { Dorsal } \\
\text { fin } \\
\text { spines }\end{array}$} & \multirow{2}{*}{$\begin{array}{c}\text { Dorsal } \\
\text { fin } \\
\text { rays }\end{array}$} & \multirow{2}{*}{$\begin{array}{c}\text { Anal } \\
\text { fin } \\
\text { rays }\end{array}$} & \multicolumn{2}{|c|}{$\begin{array}{l}\text { Pectoral } \\
\text { fin rays }\end{array}$} & \multirow{2}{*}{$\begin{array}{l}\text { Pelvic fin } \\
\text { spine } \\
\text { and rays }\end{array}$} & \multirow{2}{*}{$\begin{array}{c}\text { Preoper- } \\
\text { cular } \\
\text { spines }\end{array}$} & \multirow{2}{*}{$\begin{array}{c}\text { Ventral } \\
\text { midline } \\
\text { melano- } \\
\text { phores }\end{array}$} \\
\hline & & & & Left & Right & & & \\
\hline 6.9 & - & - & - & - & - & - & - & - \\
\hline 7. & - & - & - & - & - & - & - & - \\
\hline 15.4 & $\mathrm{X}$ & 31 & 30 & 16 & 16 & I,3 & $4+4$ & - \\
\hline
\end{tabular}

Table 16.-Measurements $(\mathrm{mm})$ of larvae of Triglops sp. (Specimens above dashed line are preflexion, that below is postflexion.)

\begin{tabular}{ccccccccc}
\hline $\begin{array}{c}\text { Body } \\
\text { length }\end{array}$ & $\begin{array}{c}\text { Head } \\
\text { length }\end{array}$ & $\begin{array}{c}\text { Snout } \\
\text { length }\end{array}$ & $\begin{array}{c}\text { Eye } \\
\text { diameter }\end{array}$ & $\begin{array}{c}\text { Snout to } \\
\text { anus length }\end{array}$ & $\begin{array}{c}\text { Body depth } \\
\text { at pectoral } \\
\text { fin base }\end{array}$ & $\begin{array}{c}\text { Pectoral } \\
\text { fin length }\end{array}$ & $\begin{array}{c}\text { 2d preoper- } \\
\text { cular } \\
\text { spine length }\end{array}$ & $\begin{array}{c}\text { Parietal } \\
\text { spine length }\end{array}$ \\
\hline 6.9 & 1.9 & 0.20 & 0.90 & 2.6 & 1.5 & 0.39 & - & - \\
7.4 & 1.8 & 0.20 & 0.86 & 3.1 & 1.4 & 0.39 & - & - \\
15.4 & 4.4 & 0.80 & 1.4 & 6.8 & 3.2 & 2.9 & 0.62 & $B^{1}$ \\
\hline
\end{tabular}




\section{Triglops sp.}
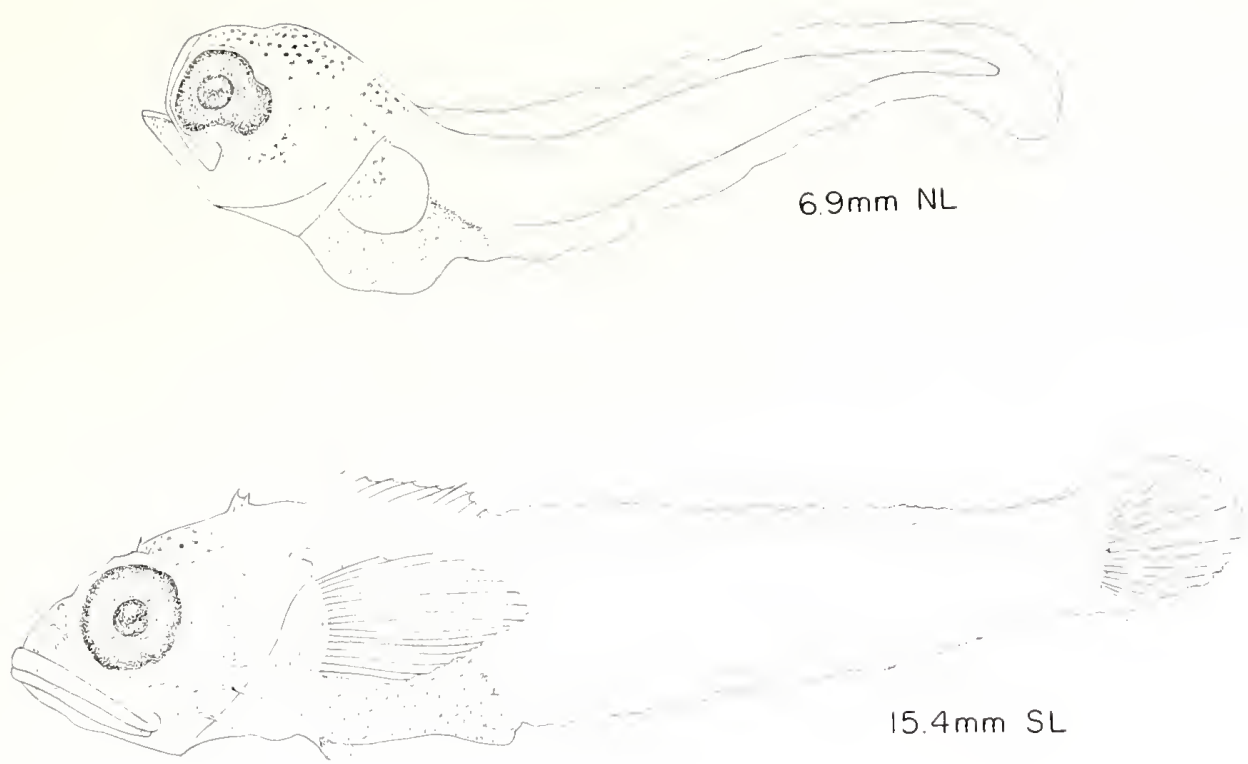

Figure 10.-Larvae of Triglops sp.

specimen we have is $15.4 \mathrm{~mm}$. It has a large complement of fin rays or elements although the fins do not appear to be fully formed and transformation probably takes place at a somewhat larger size. We have taken only four specimens.

The larvae have a distinctive, heavily pigmented gut, and postanal ventral midline melanophores are absent. Pigment occurs over the head and nape region of the smallest larvae, but the nape pigment is no longer visible on the largest specimen. Pigment also occurs on the pectoral fin base. The rest of the body remains unpigmented.

Head spines on the largest specimen include a double row (anterior and posterior series) of 4 preopercular spines, a parietal spine, a nuchal spine, 2 spines in the posttemporal-supracleithral region, and 2 spines in the postocular region.

The larvae are relatively slender with depth at the pectoral base ranging from 19 to $22 \%$ SL. Snout to anus length ranges from 38 to $44 \% \mathrm{SL}$. The larvae have a high number of myomeres, $\sim 45-46$, which distinguishes them from most other cottids in the region. The oblique mouth, angular jaw, and pointed snout further dis. tinguish these larvae.

Discussion. No species of Triglops are reported from Oregon waters although our Triglops sp. larvae were all collected $28 \mathrm{~km}$ off the Oregon coast in March and April. The larvae could be a product of spawning in more northern waters off Washington where two species of Triglops reportedly occur, T. macellus and T. pingeli (Hart 1973).
But coastal currents generally flow northward during that time of year, minimizing the likelihood that the larvae were transported southward. The occurrence of relatively undeveloped larvae off the mid-Oregon coast indicates a species of Triglops may occur and spawn off Oregon.

Although we cannot be positive that total adult complements of fin ray elements are formed in the $15.4 \mathrm{~mm}$ specimen, the counts of dorsal and anal fin rays, 31 and 30 respectively, are too high for $T$. pingeli [maximum of 28 in both fins based on Howe and Richardson (footnote $3)]$. The counts are within the range given for $T$. macellus (27-31 in both fins) as are the pectoral fin ray counts of 16 (range 15-17, based on Howe and Richardson footnote 3). However, Howe and Richardson listed a count of 51 vertebrae for one specimen of $T$. macellus. We are able to count only 47 myomeres on our larvae, seemingly too low for $T$. macellus. The range of variability of vertebrae numbers is not yet known for $T$. macellus. If the one count of 51 is at the high end of the scale, 4 less vertebrae may be within the range of variability and our larvae could well be $T$. macellus. This remains to be confirmed. Alternatively, an undescribed species of Triglops occurs off the Oregon coast which seems less plausible.

Larvae of $T$. pingeli from the Atlantic Ocean and Barents Sea presumably have a row of postanal ventral midline melanophores based on the illustrations by Ehrenbaum (1905-1909) and Rass (1949) and the discussion by Khan (1972) who compared them to larvae of $T$. murrayi which also have postanal ventral midline melanophores. In addition, $T$. pingeli also develops a row 
of melanophores along the base of the second dorsal fin by the size of $10 \mathrm{~mm}$ and a mediolateral row by $11 \mathrm{~mm}$ [Koefoed 1907 (cited by Khan 1972)]. If larvae of $T$. pingeli from the Pacific develop the same pigment pattern as those from the Atlantic and Barent Sea, they would be easily distinguishable from our Triglops sp. larvae. Head and trunk pigment and shape of $T$. pingeli resemble our Triglops $\mathrm{sp}$. indicating a generic similarity.

\section{Chitonotus pugetensis (Steindachner)}

(Figures 11, 12; Tables 17, 18)

Literature. Larvae of this species have not been previously described.

Figure 11.-Larvae of Chitonotus pugetensis.

Chitonotus pugetensis
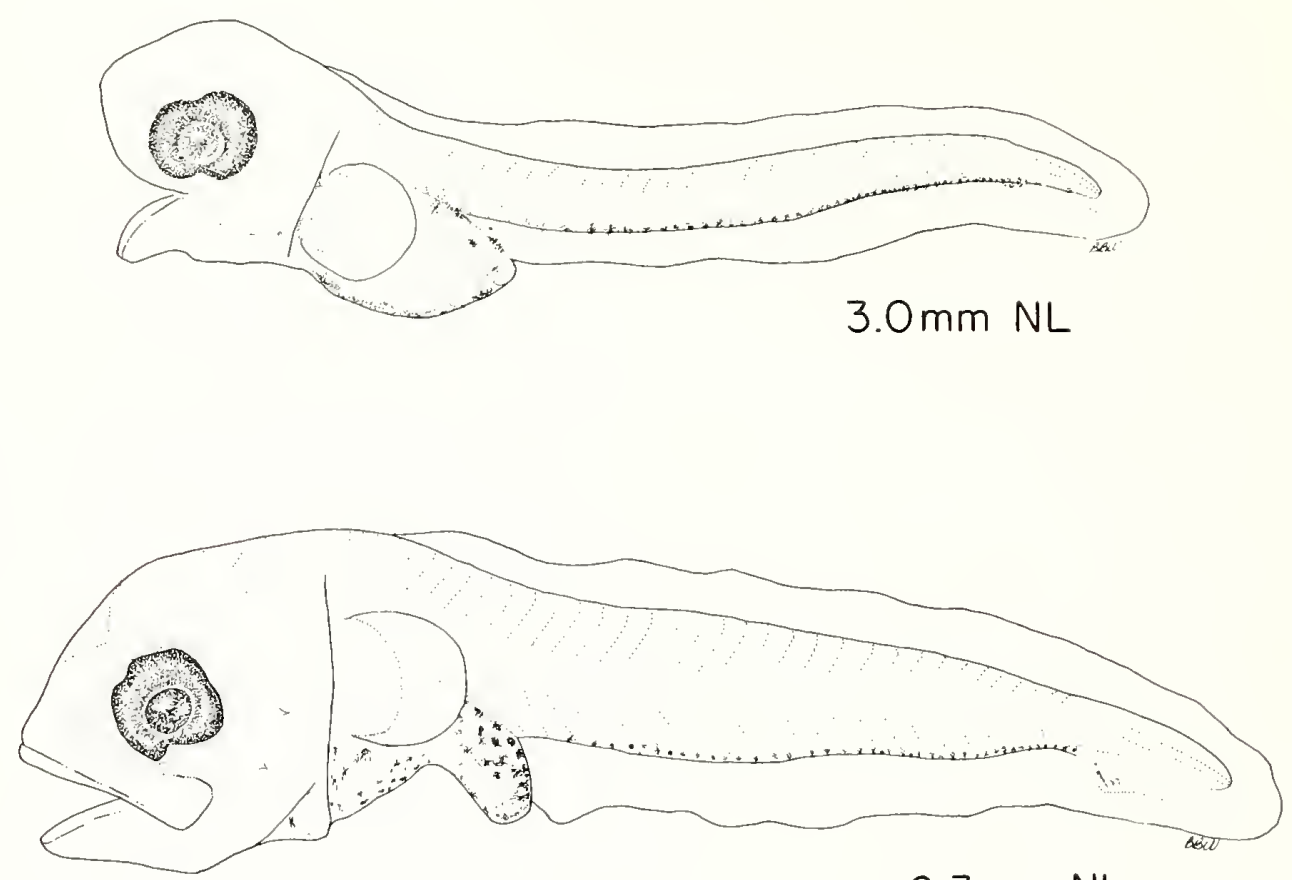

$6.3 \mathrm{~mm} \mathrm{NL}$

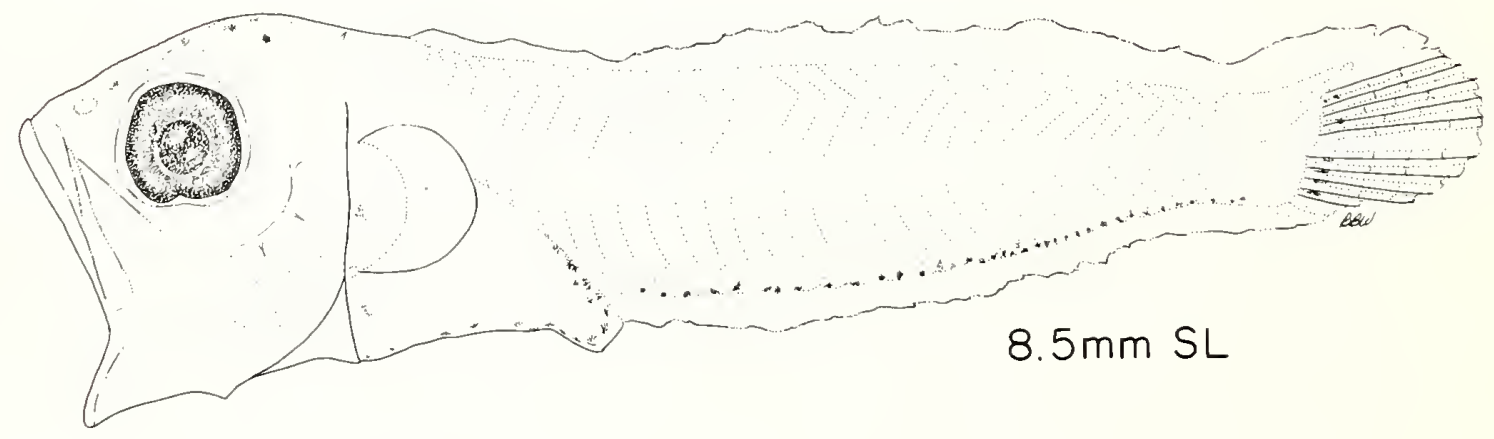




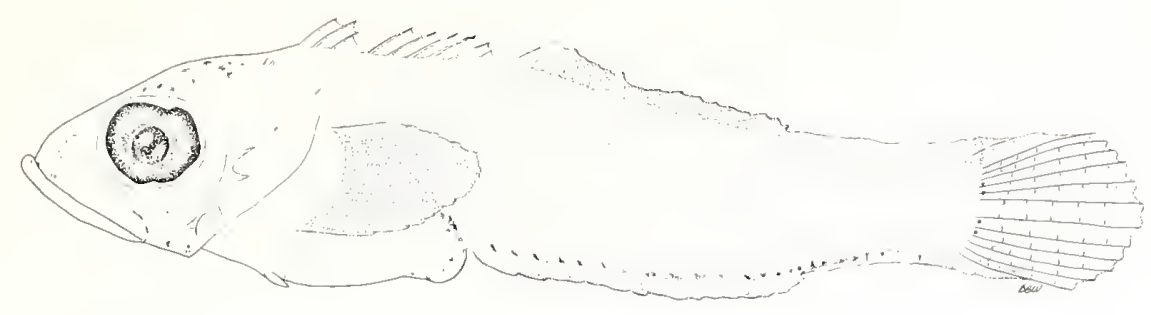

$11.5 \mathrm{~mm} \mathrm{SL}$
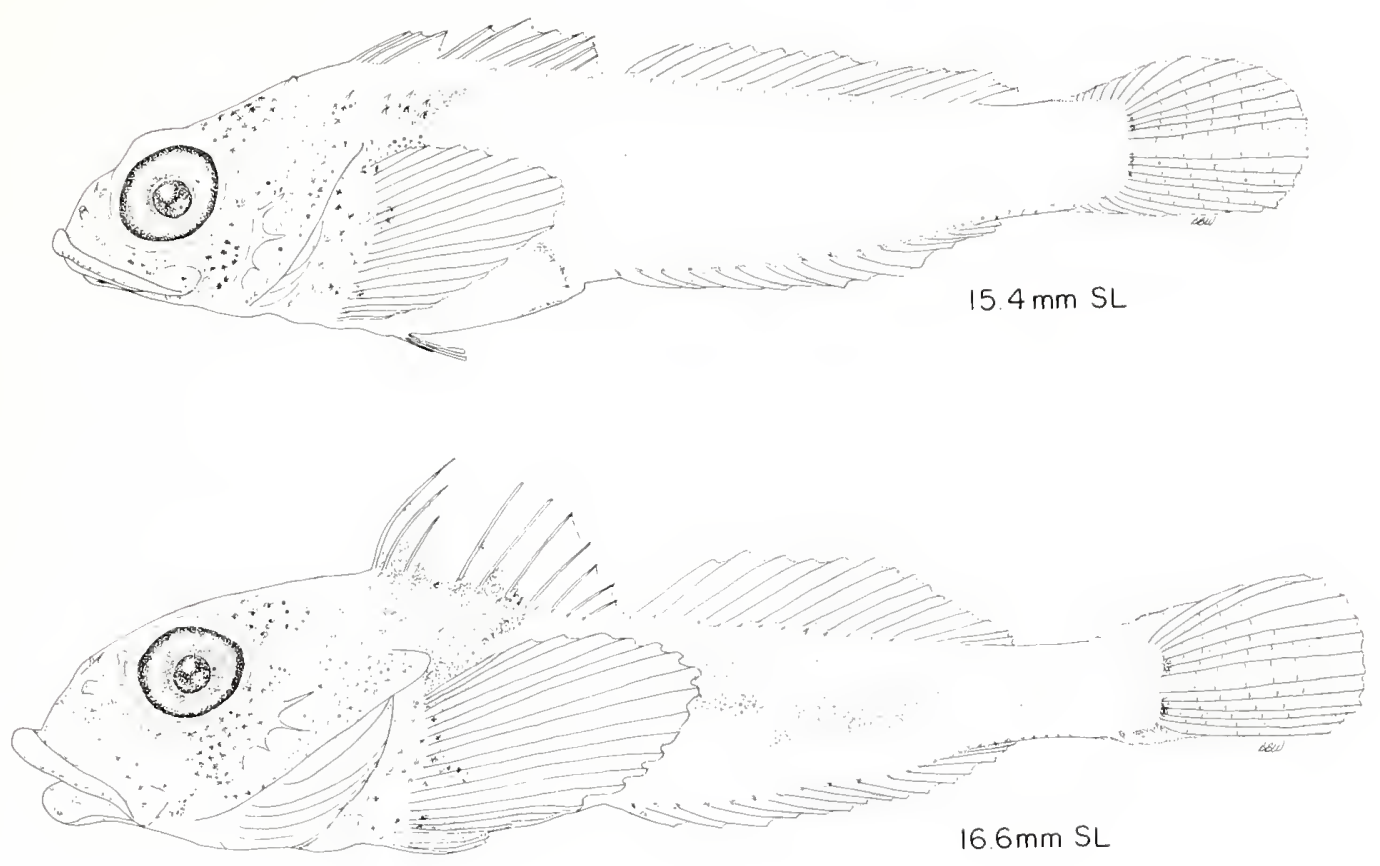

Figure 12.-Young of Chitonotus pugetensis.

Table 17.-Meristics from larvae of Chitonotus pugetensis. (Specimens above dashed line are preflexion, those below are postflexion.)

\begin{tabular}{|c|c|c|c|c|c|c|c|c|}
\hline $\begin{array}{l}\text { Body } \\
\text { length }\end{array}$ & $\begin{array}{l}\text { Dorsal } \\
\text { fin } \\
\text { spines }\end{array}$ & $\begin{array}{c}\text { Dorsal } \\
\text { fin } \\
\text { rays }\end{array}$ & $\begin{array}{c}\text { Anal } \\
\text { fin } \\
\text { rays }\end{array}$ & $\begin{array}{r}\text { Pec } \\
\text { fin } \\
\text { Left }\end{array}$ & $\begin{array}{l}\text { ctoral } \\
\text { rays } \\
\text { Right }\end{array}$ & $\begin{array}{l}\text { Pelvic fin } \\
\text { spine } \\
\text { and rays }\end{array}$ & $\begin{array}{l}\text { Preoper- } \\
\text { cular } \\
\text { spines } \\
\end{array}$ & $\begin{array}{c}\text { Ventral } \\
\text { midline } \\
\text { melano- } \\
\text { phores } \\
\end{array}$ \\
\hline 3.0 & - & - & - & - & - & - & - & 45 \\
\hline 6.3 & - & - & - & - & - & - & - & 41 \\
\hline 8.5 & -15 & & 14 & - & - & - & 4 & 37 \\
\hline 11.5 & IX & 16 & 16 & 16 & 16 & - & 4 & 24 \\
\hline 15.4 & $\mathrm{x}$ & 16 & 16 & 18 & 18 & $\mathrm{I}, 3$ & 4 & 26 \\
\hline 16.6 & $\mathrm{X}$ & 15 & 15 & 17 & 17 & $\mathrm{I}, 3$ & 4 & 24 \\
\hline
\end{tabular}

${ }^{1}$ Dorsal fin spines and soft rays cannot be distinguished.
Distinguishing Features. The smallest larvae we have taken are $\sim 3 \mathrm{~mm}$ and probably recently hatched. The largest pelagic specimen, $16.6 \mathrm{~mm}$, is beginning to transform to the juvenile stage as evidenced by increasing pigmentation.

The dorsolateral surface of the gut is only moderately pigmented. Additional pigment distinctively lines the ventral margin of the abdominal cavity. Pigment occurs on the head by $8.5 \mathrm{~mm}$ and is added to the head region through later development. A series of melanophores lines the ventral body margin postanally. These ventral midline melanophores always number $>20$ and usually $>40$ in preflexion larvae $<6 \mathrm{~mm}$. This is the highest number of ventral midline melanophores for preflexion 
Table 15.-Measurements $(\mathrm{mm})$ of larvae of Chitonotus pugetensis. (Specimens above dashed line are preflexion, those below are postflexion.)

\begin{tabular}{|c|c|c|c|c|c|c|c|c|}
\hline $\begin{array}{l}\text { Body } \\
\text { length }\end{array}$ & $\begin{array}{l}\text { Head } \\
\text { length }\end{array}$ & $\begin{array}{l}\text { Snout } \\
\text { length }\end{array}$ & $\begin{array}{c}\text { Eye } \\
\text { diameter }\end{array}$ & $\begin{array}{c}\text { Snout to } \\
\text { anus length }\end{array}$ & $\begin{array}{l}\text { Body depth } \\
\text { at pectoral } \\
\text { fin base }\end{array}$ & $\begin{array}{r}\text { Pectoral } \\
\text { fin length }\end{array}$ & $\begin{array}{l}\text { 2d preoper- } \\
\text { cular } \\
\text { spine length }\end{array}$ & $\begin{array}{c}\text { Parietal } \\
\text { spine length }\end{array}$ \\
\hline 3.0 & 0.66 & 0.23 & 0.70 & 0.54 & 1.1 & 0.20 & - & - \\
\hline 6.3 & 1.7 & 0.43 & 0.62 & 2.6 & 1.5 & 0.31 & - & - \\
\hline \multicolumn{9}{|l|}{$\ldots$} \\
\hline 8.5 & 2.2 & 0.72 & 0.80 & 4.0 & 2.0 & 0.64 & 0.12 & 0.04 \\
\hline 11.5 & 3.5 & 0.88 & 1.1 & 5.3 & 2.8 & 16 & 0.23 & $\mathrm{BR}^{1}$ \\
\hline 15.4 & 4.6 & 1.1 & 1.6 & 7.4 & 3.8 & 2.6 & 0.31 & 0.12 \\
\hline 16.6 & 6.2 & 1.8 & 1.7 & 7.6 & 3.9 & 4.0 & 0.40 & - \\
\hline
\end{tabular}

$\mathrm{BR}=$ Broken

larvae of any species described in this guide. The posterior melanophores in this series appear to be closer together than the anterior ones. The number and spacing of the ventral midline melanophores help distinguish small larvae. Melanophores occur along the base of the caudal fin after it develops. As transformation to the juvenile stage approaches pigment is added to the anterior portion of the spinous dorsal fin, in the nape region, in blotches along the lateral midline, and on the pectoral fin.

The preopercle becomes armed with 4 prominent spines, some of which are visible on larvae as small as $\sim 6$ $\mathrm{mm}$. With development, the upper 2 spines become larger than the 2 lower ones. Small parietal and nuchal spines develop during the postflexion period and fuse together as 1 spine. Several small spines also develop in the posttemporal and supracleithral region. These latter two sets of spines are inconspicuous on the $16.6 \mathrm{~mm}$ specimen. A nasal spine is visible by $15 \mathrm{~mm}$.

Small larvae of $C$. pugetensis somewhat resemble liparid larvae in shape except that they have fewer myomeres. With development, the snout becomes rather pointed in appearance and the body shape resembles that of Icelinus spp. where the body outline narrows distinctively near the caudal peduncle. Body depth at the pectoral fin base remains $\sim 23-25 \% \mathrm{SL}$. Snout to anus length ranges from $\sim 41$ to $48 \%$ SL and pectoral fin length increases to $\sim 24 \%$ SL during the larval period. The adult complement of fin rays (except dorsal spines) can be counted in $11.5 \mathrm{~mm}$ larvae. The deep emargination between the third and fourth dorsal fin spines, a diagnostic character for C. pugetensis, is noticeable by $11.5 \mathrm{~mm}$.

Discussion. Chitonotus is a monotypic genus in the northeast Pacific. The larvae are rather distinctive, and with the aid of the above characters, they are not easily confused with other forms off Oregon.

\section{Cottus asper Richardson}

(Figure 13; Tables 19, 20)

Literature. Larvae of Cottus asper were briefly described and illustrated $(5.5,9.0,10.8 \mathrm{~mm}$ TL) by Stein (1972). We did not review literature on larvae of strictly freshwater species of Cottus.

Distinguishing Features. Larvae hatch $\sim 5 \mathrm{~mm}$ and begin to develop juvenile pigmentation $\sim 10 \mathrm{~mm}$ as evidenced by an increase in the number of melanophores in the head region.

Cottus asper larvae are relatively lightly pigmented. A few melanophores cover the dorsal surface of the gut and several elongate melanophores line the ventral margin of the abdominal cavity and throat. About 15-20 evenly spaced melanophores occur along the ventral midline of the tail beginning near the anus. These decrease in number during development while a few melanophores are added laterally over the gut and one appears at the ventral edge of the preopercle. As transformation begins more pigment is added to the head, base of pectoral fin, over the gut, and along the base of the caudal fin.

Table 19.-Meristics from larvae of Cottus asper. (Specimen above dashed line is preflexion, those below are postflexion.)

\begin{tabular}{|c|c|c|c|c|c|c|c|c|}
\hline \multirow{2}{*}{$\begin{array}{r}\text { Body } \\
\text { length }\end{array}$} & \multirow{2}{*}{$\begin{array}{l}\text { Dorsal } \\
\text { fin } \\
\text { spines }\end{array}$} & \multirow{2}{*}{$\begin{array}{c}\text { Dorsal } \\
\text { fin } \\
\text { rays }\end{array}$} & \multirow{2}{*}{$\begin{array}{l}\text { Anal } \\
\text { fin } \\
\text { rays }\end{array}$} & \multicolumn{2}{|c|}{$\begin{array}{l}\text { Pectoral } \\
\text { fin rays }\end{array}$} & \multirow{2}{*}{$\begin{array}{l}\text { Pelvic fin } \\
\text { spine } \\
\text { and rays }\end{array}$} & \multirow{2}{*}{$\begin{array}{c}\text { Preoper- } \\
\text { cular } \\
\text { spines }\end{array}$} & \multirow{2}{*}{$\begin{array}{l}\text { Ventral } \\
\text { midline } \\
\text { melano- } \\
\text { phores }\end{array}$} \\
\hline & & & & Left & Right & & & \\
\hline 5.2 & - & - & - & - & $\mathrm{N}^{1}$ & - & - & 17 \\
\hline 8.2 & -19 & & $16 \mathrm{~B}^{3}$ & - & $\mathrm{N}$ & - & 4 & 14 \\
\hline 9.9 & IX & 18 & 16 & 19 & 18 & - & 4 & 8 \\
\hline
\end{tabular}

Table 20.-Measurements ( $\mathrm{mm}$ ) of larvae of Cottus asper. (Specimen above dashed line is preflexion, those below are postflexion.)

\begin{tabular}{|c|c|c|c|c|c|c|c|c|}
\hline $\begin{array}{l}\text { Body } \\
\text { length }\end{array}$ & $\begin{array}{l}\text { Head } \\
\text { length }\end{array}$ & $\begin{array}{l}\text { Snout } \\
\text { length }\end{array}$ & $\begin{array}{c}\text { Eye } \\
\text { diameter }\end{array}$ & $\begin{array}{l}\text { Snout to } \\
\text { anus length }\end{array}$ & $\begin{array}{l}\text { Body depth } \\
\text { at pectoral } \\
\text { fin base }\end{array}$ & $\begin{array}{l}\text { Pectoral } \\
\text { fin length }\end{array}$ & $\begin{array}{l}\text { 2d preoper- } \\
\text { cular } \\
\text { spine length }\end{array}$ & $\begin{array}{c}\text { Parietal } \\
\text { spine length }\end{array}$ \\
\hline 5.2 & 0.9 & 0.12 & 0.36 & 2.1 & 0.78 & 0.51 & - & - \\
\hline \multicolumn{9}{|c|}{ 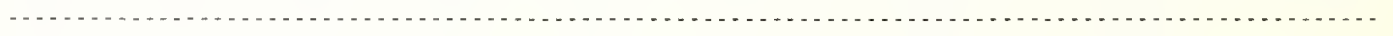 } \\
\hline 8.2 & 1.9 & 0.35 & 0.55 & 3.8 & 1.4 & 0.62 & $\sim 0.03$ & - \\
\hline 9.9 & 2.6 & 0.66 & 0.74 & 4.2 & 1.8 & 2.5 & 0.33 & - \\
\hline
\end{tabular}



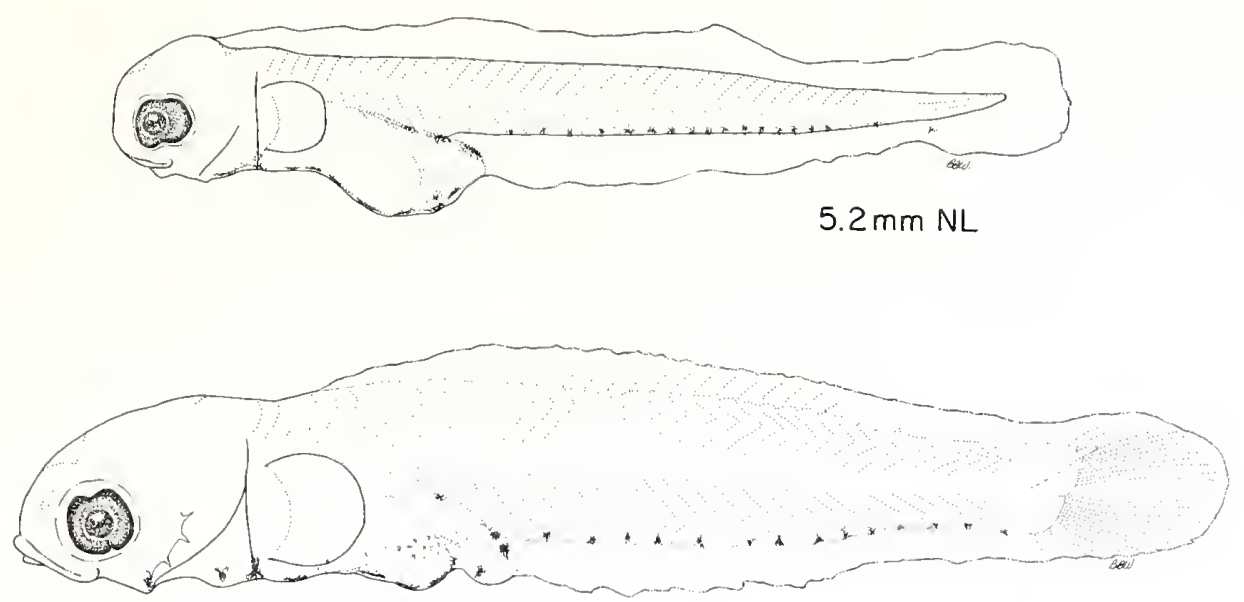

$8.2 \mathrm{~mm} \mathrm{SL}$

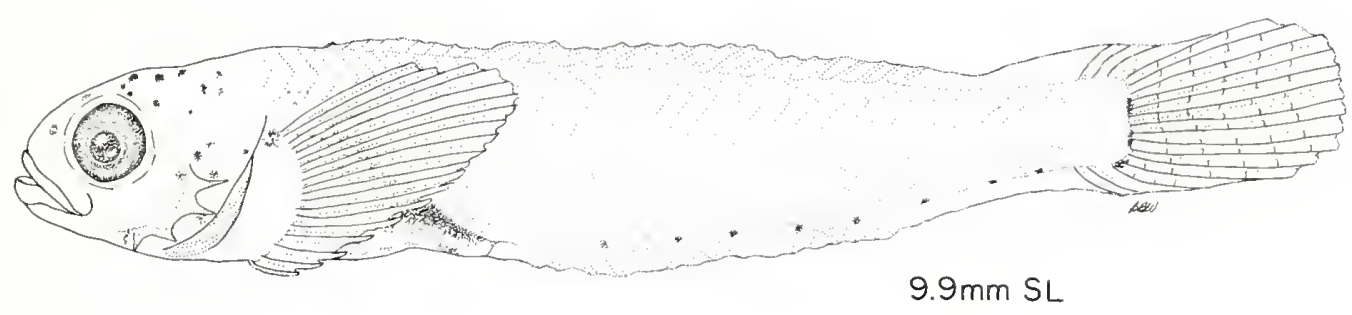

Figure 13.-Larvae of Cottus asper.

Four pronounced spines develop on the preopercular margin, evident in $8 \mathrm{~mm}$ larvae. No additional head spines form with development.

The shape of C. asper larvae is rather distinctive, being somewhat blennioid in appearance. This is partly related to the characteristic coiling and shape of the gut which is unlike any of the other cottids described here. Snout to anus length is usually between 40 and $46 \%$ SL. Body depth at the pectoral fin base is slender relative to body length, usually $<20 \% \mathrm{SL}$. Total fin rays or elements are countable by $\sim 10 \mathrm{~mm}$.

Discussion. Two species of Cottus, C. asper and C. aleuticus, are found in brackish water off Oregon. Only larvae of $C$. asper have been identified in coastal plankton collections. Ringstad ${ }^{8}$ provided evidence that in a British Columbia coastal stream most $C$. asper spawn in the estuary while C. aleuticus spawn primarily in fresh water. Thus larvae of $C$. aleuticus may simply not occur

\footnotetext{
${ }^{8}$ Ringstad, N. R. 1974. Food competition between freshwater sculpins (Genus Cottus) and juvenile coho salmon (Oncorhynchus kisutch): an experimental and ecological study in a British Columbia coastal stream. Environ. Can., Fish. Mar. Serv., Tech. Rep. 457, 88 p.
}

in coastal plankton. Larvae of C. aleuticus have not been described. Meristics, especially anal (usually $>15$ for asper and $<15$ for aleuticus) fin ray numbers will generally separate the two (Scott and Crossman 1973; Howe and Richardson footnote 3).

\section{Enophrys bison (Girard)}

(Figure 14; 'Tables 21, 22)

Literature. Blackburn (1973) illustrated and briefly de-

Table 21.-Meristics from larvae of Enophrys bison. (Specimen between dashed lines is undergoing notochord flexion.)

\begin{tabular}{|c|c|c|c|c|c|c|c|c|}
\hline \multirow{2}{*}{$\begin{array}{l}\text { Body } \\
\text { length }\end{array}$} & \multirow{2}{*}{$\begin{array}{l}\text { Dorsal } \\
\text { fin } \\
\text { spines }\end{array}$} & \multirow{2}{*}{$\begin{array}{l}\text { Dorsal } \\
\text { fin } \\
\text { rays }\end{array}$} & \multirow{2}{*}{$\begin{array}{c}\text { Anal } \\
\text { fin } \\
\text { rays }\end{array}$} & \multicolumn{2}{|c|}{$\begin{array}{l}\text { Pectoral } \\
\text { fin rays }\end{array}$} & \multirow{2}{*}{$\begin{array}{l}\text { Pelvic fin } \\
\text { spine } \\
\text { and rays }\end{array}$} & \multirow{2}{*}{$\begin{array}{l}\text { Preoper- } \\
\text { cular } \\
\text { spines }\end{array}$} & \multirow{2}{*}{$\begin{array}{c}\text { Ventral } \\
\text { midline } \\
\text { melano- } \\
\text { phores }\end{array}$} \\
\hline & & & & Left & Right & & & \\
\hline 4.8 & - & - & - & - & $\mathrm{N}^{1}$ & - & - & 14 \\
\hline 7.0 & - & - & - & - & $\mathrm{N}$ & - & 4 & 11 \\
\hline 9.1 & IX & 11 & 9 & 16 & $\mathrm{~N}$ & I, 3 & 4 & 10 \\
\hline
\end{tabular}


Enophys bison
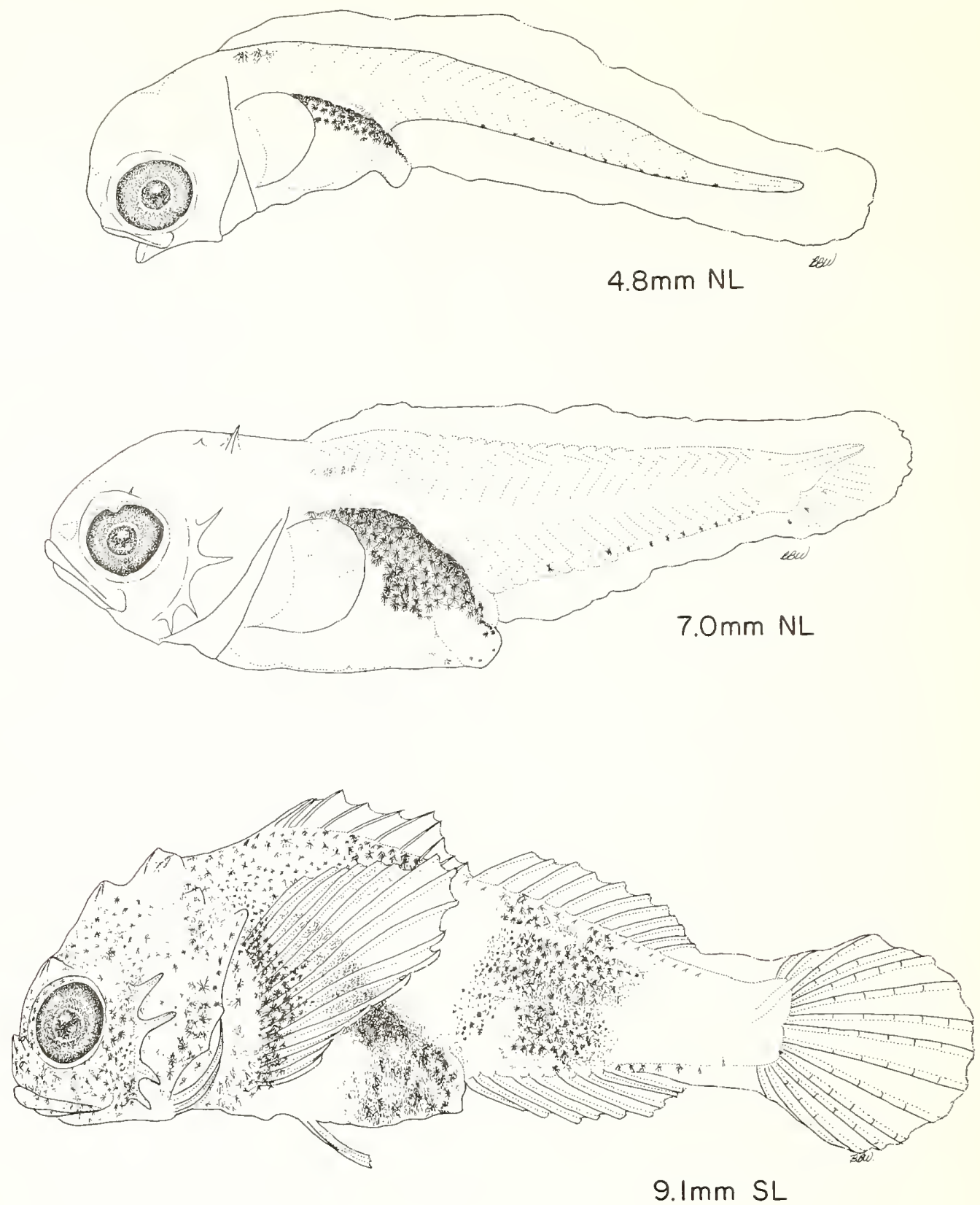

Figure 14.-Young of Enophrys bison. 
Table 22.-Measurements ( $\mathrm{mm}$ ) of larvae of Enophrys bison. (Specimen between dashed line is undergoing notochord flexion.)

\begin{tabular}{|c|c|c|c|c|c|c|c|c|}
\hline $\begin{array}{l}\text { Body } \\
\text { length }\end{array}$ & $\begin{array}{l}\text { Head } \\
\text { length }\end{array}$ & $\begin{array}{l}\text { Snout } \\
\text { length }\end{array}$ & $\begin{array}{c}\text { Eye } \\
\text { diameter }\end{array}$ & $\begin{array}{l}\text { Snout to } \\
\text { anus length }\end{array}$ & $\begin{array}{l}\text { Body depth } \\
\text { at pectoral } \\
\text { fin base }\end{array}$ & $\begin{array}{l}\text { Pectoral } \\
\text { fin length }\end{array}$ & $\begin{array}{l}\text { 2d preoper- } \\
\text { cular } \\
\text { spine length }\end{array}$ & $\begin{array}{c}\text { Parietal } \\
\text { spine length }\end{array}$ \\
\hline 4.8 & 1.1 & 0.2 & 0.55 & 2.3 & 1.1 & 0.37 & - & - \\
\hline 7.0 & 2.0 & 0.5 & 0.66 & 3.8 & 1.9 & 0.55 & 0.35 & 0.27 \\
\hline 9.1 & 3.4 & 0.6 & 0.90 & 5.0 & 3.4 & 2.08 & 0.43 & 0.27 \\
\hline
\end{tabular}

scribed a $7.5 \mathrm{~mm}$ larva of E. bison and Marliave (1975) a $10 \mathrm{~mm}$ TL larva. Misitano (1978) described a developmental series, including eggs, of $E$. bison $(5.0,5.4,5.8$, $6.7,7.1,7.6 \mathrm{~mm} \mathrm{SL}$ ) based on laboratory-reared material.

Distinguishing Features. Larvae are $\sim 5 \mathrm{~mm}$ at hatching. The addition of juvenile pigment may begin in specimens as small as $7 \mathrm{~mm}$ in the laboratory but may occur later in the natural environment based on our material. Transition from pelagic to benthic habitat begins in specimens as small as 7.6-7.8 $\mathrm{mm}$ in the laboratory but Marliave (1975) captured a $10 \mathrm{~mm}$ TL transforming specimen in the plankton and we took transforming specimens up to $\sim 9.5 \mathrm{~mm}$ in the neuston. Even with this variation, transformation to juveniles takes place at a relatively small size in $E$. bison compared to other known cottids.

Pigmentation over the dorsolateral surface of the gut is characteristic and intense. Melanophores often appear as tightly packed discrete circles. Additional melanophores are on the ventrolateral surface of the gut of fresh material but are faded on our smallest specimens. Melanophores are present on the nape, appearing very dark in freshly preserved specimens. The number of postanal ventral midline melanophores is usually $\leq 15$. A distinctive space of several myomeres in length exists between the anus and the anteriormost ventral melanophore. The ventral midline melanophore series is relatively inconspicuous, compared to other cottid species. During development, pigment is added to the head which becomes entirely covered with melanophores by transformation. Melanophores are added beneath the spinous dorsal fin forming a band extending to the gut, to the base of the pectoral fin, to the ventrolateral region of the gut, and eventually beneath the second dorsal fin extending as a band to the ventral body margin. A few melanophores appear at the base of the caudal fin.

Larvae of $E$. bison develop very prominent head spines. Four pronounced preopercular spines are visible on all but the smallest larvae. The length of the second preopercular spine is $18 \% \mathrm{HL}$ in a specimen undergoing notochord flexion. They also develop a rather large parietal spine, visible by $\sim 6 \mathrm{~mm}$. With development, a nuchal spine appears posterior to the parietal and fuses with it, and another spine develops on the parietal ridge anterior to the parietal spine. A postocular spine develops over the eye. A spinelike bump develops in late larvae in the posttemporal-supracleithral region and a nasal spine appears on the snout. Two spiny tips (midopercular and interopercular-subopercular) can be seen on the gill cover margin.

All but the smallest larvae are relatively deep bodied with body depth at the pectoral fin base increasing to $\sim 37 \%$ SL on our transforming specimens. Snout to anus length increases from $\sim 48$ to $55 \%$ SL with development. The preanal finfold described by Misitano (1978) in larvae $<6.6 \mathrm{~mm}$ was not visible on our specimens probably because of poor condition. All fin rays are countable by the onset of the transformation period at $\sim 9 \mathrm{~mm}$ in our material. Pectoral fin length reaches $23 \%$ SL by transformation. Enophrys bison larvae have a characteristically low number of myomeres (vertebrae $=29-31$ ) (Howe and Richardson footnote 3 ) which helps to distinguish them from other cottids off Oregon most of which have $>31$ vertebrae (Table 1 ).

Discussion. Only one species of Enophrys occurs off Oregon and the larvae are rather distinctive and not likely to be confused with other species. However, two or three additional species of Enophrys may occur in the northeast Pacific, E. diceraus, E. lucasi, and E. taurina (Sandercock and Wilimovsky 1968; Quast and Hall 1972). Their larvae have not yet been described. Whether larval characters useful for $E$. bison (i.e., distinctive gut pigment, intense nape pigment, pronounced head spines, gap between anus and first ventral midline melanophore, small size at transformation) would be helpful in distinguishing larvae of the other species remains to be determined. Certainly the low number of vertebrae (2629 ) of $E$. taurina (Howe and Richardson footnote 3 ) will be a useful character. Larvae of $E$. bubalis and $E$. lilljeborgi (Russell 1976) closely resemble $E$. bison with some differences in pigmentation and spination.

\section{Icelinus spp.}

(Figures 15, 16, 17; Tables 23, 24)

Literature. A $4.3 \mathrm{~mm}$ larva resembling this type was illustrated and described by Blackburn (1973) as Cottid 3. These larvae were referred to as Icelinus $\mathrm{sp}$. 1 by Richardson (footnote 4) and Richardson and Pearcy (1977).

Distinguishing Features. The smallest larvae in our collections are $\sim 3-4 \mathrm{~mm}$ and probably recently hatched. The largest specimens we have collected pelagically are 


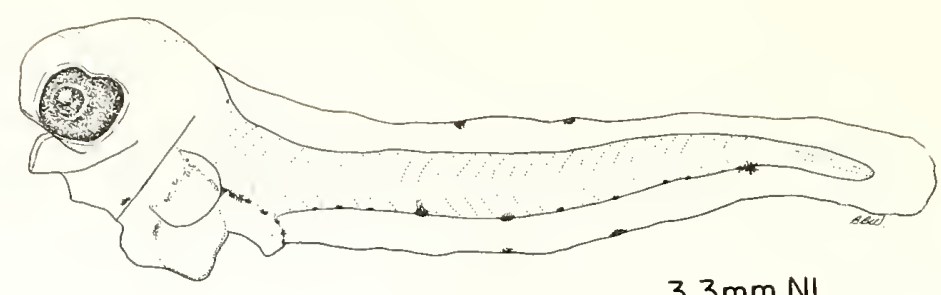

$3.3 \mathrm{~mm} \mathrm{NL}$

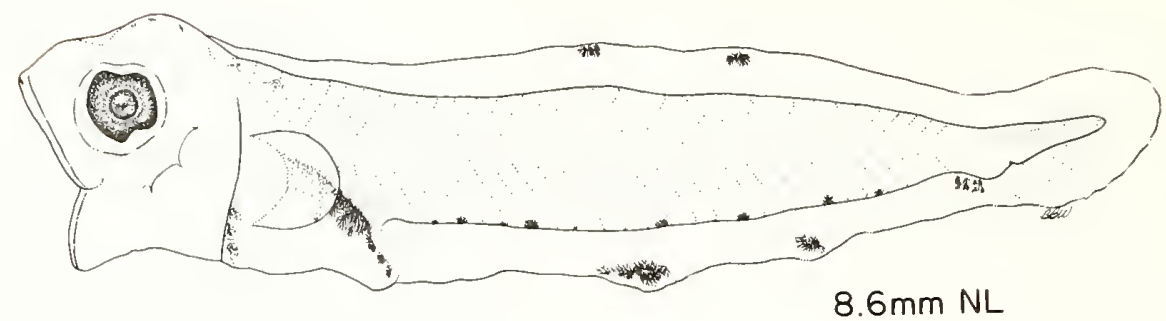

$8.6 \mathrm{~mm} \mathrm{NL}$

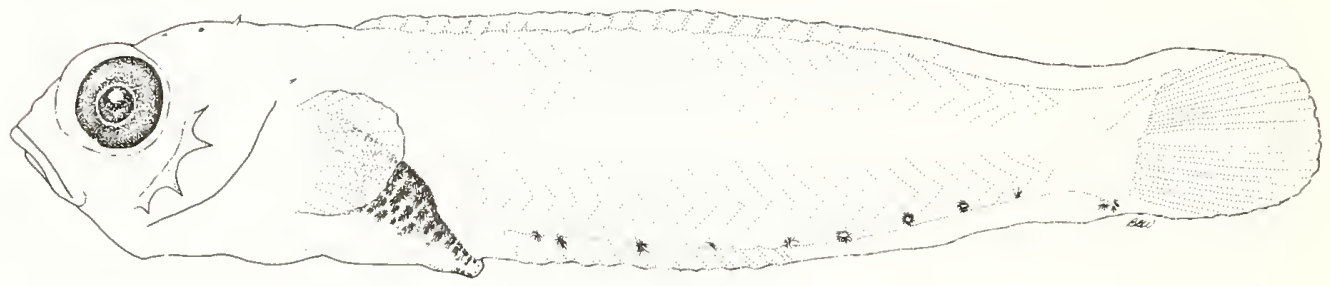

$10.9 \mathrm{~mm} \mathrm{SL}$

Figure 15.-Larvae of Icelinus spp.

$\sim 17-18 \mathrm{~mm}$, some taken in neuston tows, and they are beginning to develop juvenile pigmentation.

Larvae up to $\sim 8-9 \mathrm{~mm}$ are characterized by a series of large melanistic spots on the dorsal and ventral finfold, when intact. Most all of our specimens have 2 spots dorsally and ventrally but one had 3 ventral spots, and Blackburn's (1973) specimen had 3 spots dorsally and ventrally. Whether the number of finfold spots is a specific character or merely individual variation is not known at this time. Moderate pigment occurs over the dorsolateral surface of the gut and some melanophores are present near the base of the cleithrum. A series of distinctive melanophores, usually $<15$, occurs along the ventral midline of the tail beginning immediately behind the anus. These melanophores vary in size with some of them appearing more pronounced than others. One or several melanophores clustered at the posterior end of this ventral row distinctively appear at the ventral margin of the caudal fin base after it is formed. With development pigment is added to the head and over the gut with little additional change. Some larger specimens, $>12 \mathrm{~mm}$, have 2 distinct melanophores on the dorsal midline in the tail region. Whether this is a specific character is unknown, but we have been unable to link a complete developmental series together based on the presence of these dorsal melanophores. Some specimens, with and without dorsal midline melanophores, have an additional distinct pigment spot on the dorsalmost rays of the caudal fin near its base. In specimens nearing transformation, pigment increases over the head region, on the spinous dorsal fin, and on the pectoral fin base. 

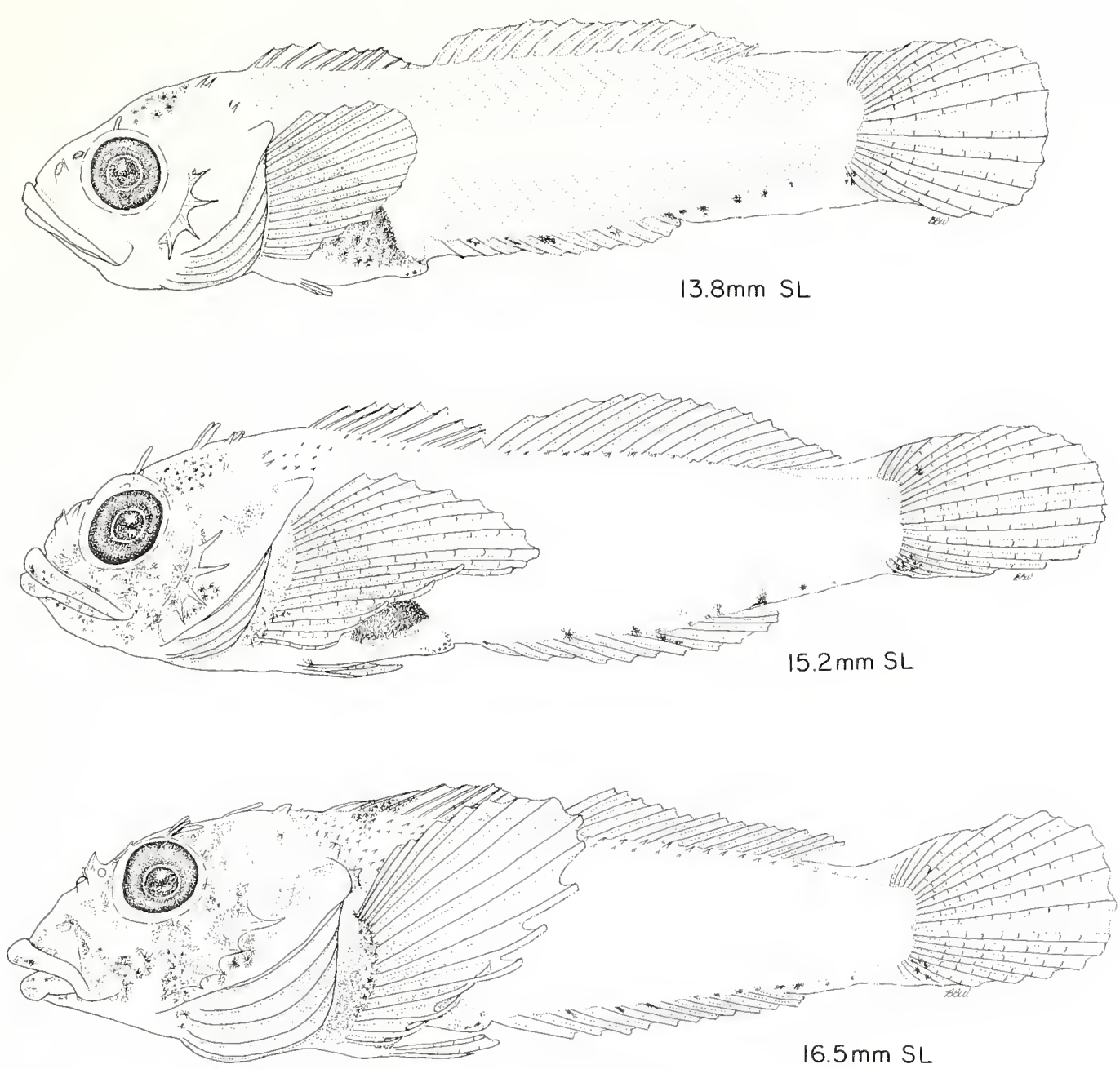

Figure 16.-Young of Icelinus spp.

Spines are first noticeable on the preopercle $\sim 8.9 \mathrm{~mm}$ and 4 are obvious by $10-11 \mathrm{~mm}$. The upper one becomes somewhat larger than the rest. Parietal and nuchal spines develop and fuse together. Several spines appear in the posttemporal-supracleithral region eventually being reduced to bumps. These are difficult to distinguish from developing spinelike scales along the lateral line and below the spinous dorsal fin. A nasal spine is obvious on the largest specimens.

The gut shape is rather distinctive in larvae of Icelinus spp. Snout to anus length is relatively short in small larvae, $<40 \%$ SL, but increases to $\sim 50 \%$ SL on larger specimens. Body depth at the pectoral fin base is $\sim 20 \%$ SL in small larvae and $\sim 25-30 \%$ SL on older larvae. Larvae of Icelinus spp. have a very characteristic body shape. Body depth appears to be constricted just behind the anus, bulges out slightly in the midtail region, and then narrows distinctively again near the tail tip or caudal peduncle. They also develop a rather pointed snout which is apparent on larvae $>8 \mathrm{~mm}$. Pectoral fin length is $\sim 25-30 \%$ SL on the largest specimens. The adult complement of fin rays or elements is countable on specimens $>12 \mathrm{~mm}$ including the diagnostic pelvic fin count of $I, 2$.

Discussion. Identification of the largest specimens to the genus level was relatively easy since Icelinus is the only representative off Oregon except Zesticelus profundorum with 2 pelvic fin rays. The distinctive body shape and pigmentation helped link the larval series to- 


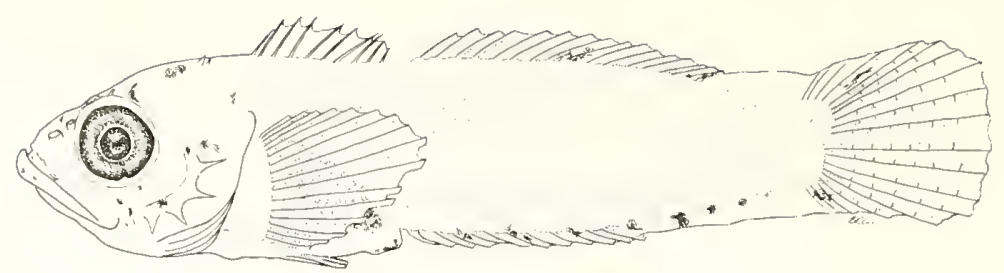

$12.5 \mathrm{~mm} \mathrm{SL}$

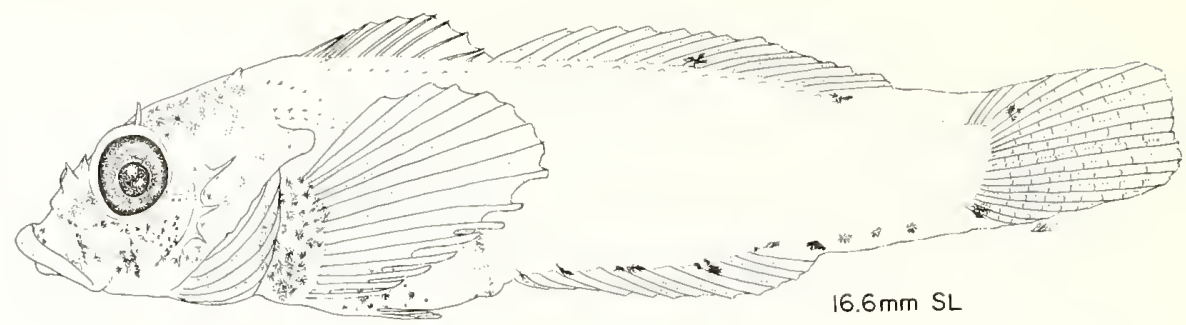

Figure 17.-Young of Icelinus spp.

Table 23.-Meristics from larvae of Icelinus spp. (Specimen between dashed line is undergoing notochord flexion.) $\left\{^{*}=\right.$ Stained with Alizarin Red S; ${ }^{* *}=$ Dorsal fin spines and soft rays cannot be distinguished; $+=$ Form with two melanophores on dorsal midline; $\mathrm{N}=$ Not examined.]

\begin{tabular}{|c|c|c|c|c|c|c|c|c|c|c|c|c|c|c|c|}
\hline \multirow[b]{3}{*}{$\begin{array}{r}\text { Body } \\
\text { length }\end{array}$} & & & \multirow{3}{*}{$\begin{array}{l}\text { Anal } \\
\text { fin } \\
\text { rays }\end{array}$} & \multirow{3}{*}{\multicolumn{2}{|c|}{$\begin{array}{l}\text { Pectoral } \\
\text { fin rays }\end{array}$}} & \multirow{3}{*}{$\begin{array}{l}\text { Pelvic } \\
\text { fin } \\
\text { spine } \\
\text { \& rays }\end{array}$} & \multirow{3}{*}{$\begin{array}{l}\text { Preoper- } \\
\text { cular } \\
\text { spines }\end{array}$} & \multirow{3}{*}{$\begin{array}{c}\text { Ventral } \\
\text { midline } \\
\text { melano- } \\
\text { phores }\end{array}$} & \multicolumn{4}{|c|}{ Caudal fin rays } & \multirow{2}{*}{\multicolumn{2}{|c|}{ Vertebrae }} & \multirow{3}{*}{$\begin{array}{c}\text { Branchi- } \\
\text { ostegal } \\
\text { rays }\end{array}$} \\
\hline & \multirow{2}{*}{\multicolumn{2}{|c|}{ Dorsal fin }} & & & & & & & \multicolumn{2}{|c|}{ Dorsal } & \multicolumn{2}{|c|}{ Ventral } & & & \\
\hline & & & & & & & & & $\begin{array}{c}\text { Second- } \\
\text { ary }\end{array}$ & $\begin{array}{l}\text { Prin- } \\
\text { cipal }\end{array}$ & $\begin{array}{l}\text { Prin- } \\
\text { cipal }\end{array}$ & $\begin{array}{c}\text { Second- } \\
\text { ary }\end{array}$ & $\begin{array}{l}\text { Abdom- } \\
\text { inal }\end{array}$ & $\begin{array}{c}\mathrm{Cau}- \\
\text { dal }\end{array}$ & \\
\hline 3.3 & - & - & - & - & - & - & - & 10 & $\mathrm{~N}$ & $\mathrm{~N}$ & $\mathrm{~N}$ & $\mathrm{~N}$ & $\mathrm{~N}$ & $\mathrm{~N}$ & $\mathrm{~N}$ \\
\hline 5.1 & - & - & - & - & - & - & - & 11 & $\mathrm{~N}$ & $\mathrm{~N}$ & $\mathrm{~N}$ & $\mathrm{~N}$ & $\mathrm{~N}$ & $\mathrm{~N}$ & $\mathrm{~N}$ \\
\hline 8.6 & - & - & - & - & 一 & - & 3 & 10 & $\mathrm{~N}$ & $\mathrm{~N}$ & $\mathrm{~N}$ & $\mathrm{~N}$ & $\mathrm{~N}$ & $\mathrm{~N}$ & $\mathrm{~N}$ \\
\hline 10.9 & -25 & $*^{* *}$ & 12 & 15 & 15 & - & 4 & 10 & $\mathrm{~N}$ & $\mathrm{~N}$ & $\mathrm{~N}$ & $\mathrm{~N}$ & $\mathrm{~N}$ & $\mathrm{~N}$ & $\mathrm{~N}$ \\
\hline+12.5 & $\mathrm{X}$ & 16 & 12 & 16 & 16 & $\mathrm{I}, 2$ & 4 & 8 & $\mathrm{~N}$ & $\mathrm{~N}$ & $\mathrm{~N}$ & $\mathrm{~N}$ & $\mathrm{~N}$ & $\mathrm{~N}$ & $\mathrm{~N}$ \\
\hline 13.8 & $\mathrm{X}$ & 16 & 12 & 16 & 16 & $\mathrm{I}, 2$ & 4 & 10 & $\mathrm{~N}$ & $\mathrm{~N}$ & $\mathrm{~N}$ & $\mathrm{~N}$ & $\mathrm{~N}$ & $\mathrm{~N}$ & $\mathrm{~N}$ \\
\hline+14.1 & $\mathrm{X}$ & 16 & 12 & 16 & 16 & $\mathrm{I}, 2$ & 4 & 11 & $\mathrm{~N}$ & $\mathrm{~N}$ & $\mathrm{~N}$ & $\mathrm{~N}$ & $\mathrm{~N}$ & $\mathrm{~N}$ & $\mathrm{~N}$ \\
\hline $14.4^{*}$ & $\mathrm{XI}$ & 15 & 12 & 15 & 15 & $\mathrm{I}, 2$ & 4 & $\mathrm{~N}$ & 5 & 6 & 6 & 4 & 11 & 23 & 6 \\
\hline 15.2 & $\mathrm{X}$ & 16 & 12 & 15 & 15 & $\mathrm{I}, 2$ & 4 & 11 & $\mathrm{~N}$ & $\mathrm{~N}$ & $\mathrm{~N}$ & $\mathrm{~N}$ & $\mathrm{~N}$ & $\mathrm{~N}$ & $\mathrm{~N}$ \\
\hline † $15.5^{*}$ & $\mathrm{X}$ & 16 & 12 & 15 & 15 & $\mathrm{I}, 2$ & 4 & $\mathrm{~N}$ & 6 & 6 & 6 & 4 & 11 & 23 & 6 \\
\hline 16.5 & $\mathrm{X}$ & 16 & 12 & 16 & 15 & $\mathrm{I}, 2$ & 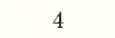 & 10 & $\mathrm{~N}$ & $\mathrm{~N}$ & $\mathrm{~N}$ & $\mathrm{~N}$ & $\mathrm{~N}$ & $N$ & $\mathrm{~N}$ \\
\hline+16.6 & $\mathrm{X}$ & 16 & 13 & 15 & 15 & $\mathrm{I}, 2$ & 4 & 12 & $\mathrm{~N}$ & $\mathrm{~N}$ & $\mathrm{~N}$ & $\mathrm{~N}$ & $\mathrm{~N}$ & $\mathrm{~N}$ & $\mathrm{~N}$ \\
\hline
\end{tabular}

gether at least at the generic level. However, specific identification is complicated because most meristics of the four Icelinus species reported to occur off Oregon, $I$. burchami, I. filamentosus, I. oculatus, and I. tenuis overlap. An anal fin ray count of 12 agrees only with $I$. burchami from Oregon waters (Table 1), a species which is reportedly rare (Howe and Richardson footnote 3). Four other northeast Pacific species of Icelinus (I. borealis, I. cavifrons, I. fimbriatus, and I. quadri- seriatus) can have an anal ray count of 12 but none reportedly occur off Oregon (Howe and Richardson footnote 3). Characters used to distinguish adults such as cirri patterns and elongated dorsal fin spines are not developed on our largest pelagic specimens. These factors together with inability to find consistent larval characters to split our Icelinus spp. larvae into subgroups potentially equivalent to species forces us to keep our indentification at the generic level. 
Table 24.-Measurements $(\mathrm{mm})$ of larvae of Icelinus spp. (Specimen between dashed line is undergoing notochord flexion.)

\begin{tabular}{|c|c|c|c|c|c|c|c|c|}
\hline $\begin{array}{l}\text { Body } \\
\text { length }\end{array}$ & $\begin{array}{l}\text { Head } \\
\text { length }\end{array}$ & $\begin{array}{l}\text { Snout } \\
\text { length }\end{array}$ & $\begin{array}{c}\text { Eye } \\
\text { diameter }\end{array}$ & $\begin{array}{c}\text { Snout to } \\
\text { anus length }\end{array}$ & $\begin{array}{l}\text { Body depth } \\
\text { at pectoral } \\
\text { fin base }\end{array}$ & $\begin{array}{l}\text { Pectoral } \\
\text { fin length }\end{array}$ & $\begin{array}{l}2 \mathrm{~d} \text { preoper- } \\
\text { cular } \\
\text { spine length }\end{array}$ & $\begin{array}{c}\text { Parietal } \\
\text { spine length }\end{array}$ \\
\hline 3.3 & 0.76 & 0.10 & 0.32 & 1.2 & 0.68 & 0.26 & - & - \\
\hline 5.1 & 0.86 & 0.12 & 0.39 & 1.7 & 1.0 & 0.31 & - & - \\
\hline 8.6 & 1.8 & 0.51 & 0.55 & 3.4 & 1.7 & 0.39 & - & - \\
\hline 10.9 & 2.5 & 0.80 & 0.88 & 4.6 & 2.2 & 1.04 & 0.22 & 0.12 \\
\hline$† 12.5$ & 4.0 & 1.0 & 1.2 & 6.2 & 3.0 & 2.2 & 0.32 & 0.26 \\
\hline 13.8 & 4.2 & 1.0 & 1.3 & 6.4 & 3.6 & 2.4 & 0.55 & 0.31 \\
\hline${ }^{\dagger} 14.1$ & 5.2 & 1.4 & 1.4 & 7.0 & 4.2 & 3.0 & 0.48 & 0.24 \\
\hline 15.2 & 5.2 & 1.2 & 1.5 & 7.7 & 4.0 & 4.1 & 0.56 & 0.24 \\
\hline 16.5 & 7.2 & 2.7 & 1.4 & 9.0 & 4.8 & 3.8 & 0.56 & 0.24 \\
\hline † 16.6 & 6.1 & 1.8 & 1.4 & 8.3 & 4.2 & 3.2 & 0.32 & 0.32 \\
\hline
\end{tabular}

${ }^{\dagger}$ Form with 2 melanophores on dorsal midline.

\section{Leptocottus armatus Girard}

(Figure 18; Tables 25, 26)

Literature. Eggs and recently hatched larvae $(\sim 4 \mathrm{~mm}$
TL) were illustrated and described by Jones (1962). Eggs and young $(8,12,13 \mathrm{~mm}$ TL) were briefly discussed by Marliave (1975) and larvae by Blackburn (1973). White

Figure 18.-Larvae of Leptocottus armatus.

\section{Leptocottus armatus}

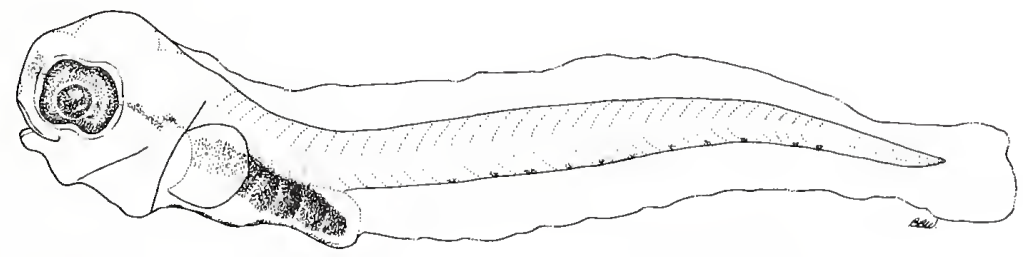

$5.1 \mathrm{~mm} \mathrm{NL}$
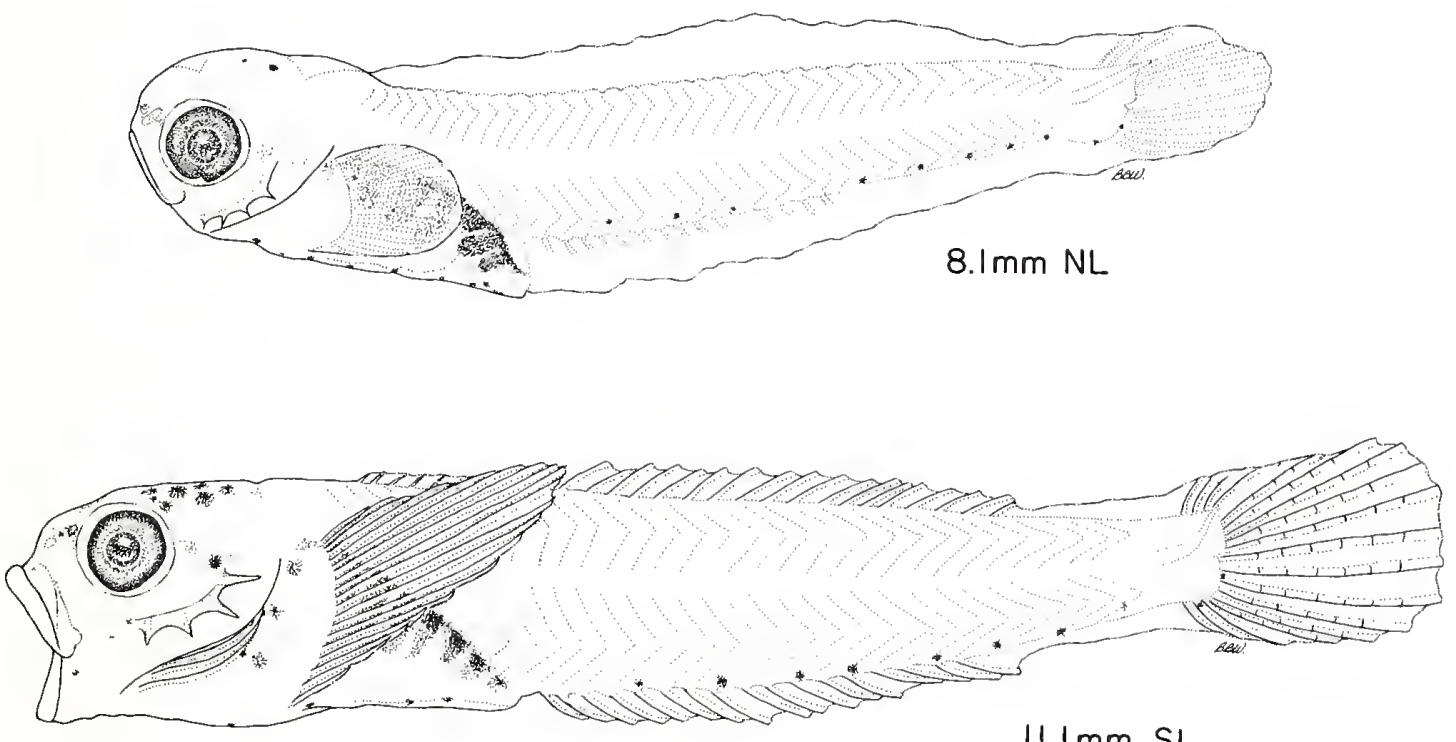

\section{$11.1 \mathrm{~mm} \mathrm{SL}$}


Table 25. - Meristics from larvae of Leptocottus armatus. (Specimen between dashed line is undergoing notochord flexion.)

\begin{tabular}{|c|c|c|c|c|c|c|c|}
\hline $\begin{array}{l}\text { Body } \\
\text { length }\end{array}$ & $\begin{array}{l}\text { Dorsal } \\
\text { fin } \\
\text { spines }\end{array}$ & $\begin{array}{l}\text { Dorsal } \\
\text { fin } \\
\text { rays }\end{array}$ & $\begin{array}{l}\text { Anal } \\
\text { fin } \\
\text { rays }\end{array}$ & $\begin{array}{l}\text { Pectoral } \\
\text { fin rays } \\
\text { Left Right }\end{array}$ & $\begin{array}{l}\text { Pelvic fin } \\
\text { spine } \\
\text { and rays }\end{array}$ & $\begin{array}{c}\text { Preoper- } \\
\text { cular } \\
\text { spines } \\
\end{array}$ & $\begin{array}{l}\text { Ventral } \\
\text { midline } \\
\text { melano- } \\
\text { phores }\end{array}$ \\
\hline 5.1 & - & - & - & $\mathrm{N}^{1}$ & - & - & 11 \\
\hline 8.1 & - & - & 15 & $-\quad \mathrm{N}$ & - & 4 & 9 \\
\hline 11.1 & VIII & 18 & 17 & $\mathrm{~N}$ & - & 4 & 7 \\
\hline
\end{tabular}

${ }^{1} \mathrm{~N}=$ Not examined.
Discussion. Leptocottus is a monotypic genus in the northwest Pacific. The larvae with their characteristic bars of pigment over the gut should not be easily confused with any other species unless damage to the specimen results in a blurring of the gut pigment. Even so, the internal pigment on the snout serves as a useful diagnostic character.

Table 26.-Measurements $(\mathrm{mm})$ of larvae of Leptocottus armatus. (Specimen between dashed lines is undergoing notochord flexion.)

\begin{tabular}{|c|c|c|c|c|c|c|c|c|}
\hline $\begin{array}{l}\text { Body } \\
\text { length }\end{array}$ & $\begin{array}{l}\text { Head } \\
\text { length }\end{array}$ & $\begin{array}{l}\text { Snout } \\
\text { length }\end{array}$ & $\begin{array}{c}\text { Eye } \\
\text { diameter }\end{array}$ & $\begin{array}{c}\text { Snout to } \\
\text { anus length }\end{array}$ & $\begin{array}{c}\text { Body depth } \\
\text { at pectoral } \\
\text { fin base } \\
\end{array}$ & $\begin{array}{l}\text { Pectoral } \\
\text { fin length }\end{array}$ & $\begin{array}{l}\text { 2d preoper- } \\
\text { cular } \\
\text { spine length }\end{array}$ & $\begin{array}{c}\text { Parietal } \\
\text { spine length }\end{array}$ \\
\hline 5.1 & 0.92 & 0.18 & 0.25 & 2.0 & 0.84 & 0.23 & - & - \\
\hline 8.1 & 1.9 & 0.31 & 0.32 & 3.2 & 1.6 & 0.78 & 0.10 & - \\
\hline 11.1 & 2.8 & 0.62 & 0.82 & 4.9 & 2.3 & 2.2 & 0.21 & - \\
\hline
\end{tabular}

(1977) illustrated (4.9 mm NL) and briefly described small larvae. Blackburn's Cottid $5(5.8 \mathrm{~mm} \mathrm{SL})$ was probably this species as was Eldridge's (1970) Cottid No. $1(5.1 \mathrm{~mm})$.

Distinguishing Features. Hatching takes place at 3.9$4.8 \mathrm{~mm}$ TL. Our largest pelagic specimen is $11 \mathrm{~mm}$ and may be nearing transformation as indicated by increased pigmentation over the head. Marliave's (1975) 13 $\mathrm{mm}$ TL specimen was transformed and had assumed a benthic habit.

Larvae have distinctive pigment over the dorsolateral surface of the gut which always appears as $\sim 6-8$ bars except in damaged specimens. No other known cottid larvae have such gut pigment. Larvae also have distinctive internal pigment on the snout at the anterior part of the forebrain and extending posteriorly from the eye to the pectoral fin. The latter becomes obscured by muscle but the former remains visible throughout the larval period. Several melanophores occur along the ventral margin of the gut cavity. A row of usually $<15$ rather prominent melanophores occurs along the ventral midline of the tail beginning about 5 myomeres posterior to the anus. With development, melanophores are added to the head and a few are present at the base of the caudal fin.

Four prominent spines develop along the preopercular margin, evident in $\sim 7 \mathrm{~mm}$ larvae. No additional head spines are formed.

Larvae are rather slender with body depth at pectoral fin base comprising $21 \%$ SL in the largest specimen. Snout to anus length increases slightly from 39 to $44 \%$ SL in the specimens examined. The snout has a rounded appearance never becoming pointed. The adult complement of dorsal, anal, and pectoral fin rays is countable by $11 \mathrm{~mm}$; however, the pelvic fins are not developed at this time.

\section{Paricelinus hopliticus Eigenmann and Eigenmann}

(Figures 19, 20; Tables 27, 28)

Literature. Larvae have not previously been described.

Distinguishing Features. The smallest larvae in our collections, $\sim 5-6 \mathrm{~mm}$ appear to be recently hatched. An $18.6 \mathrm{~mm}$ specimen is beginning to transform as evidenced by increased head pigmentation and body spination (modified scales). A $25.6 \mathrm{~mm}$ specimen captured pelagically appears to be a fully transformed juvenile.

Larvae have a distinctively pigmented gut with melanophores covering the entire abdominal cavity. Pigment is scattered over the head region. Over 30 melanophores line the ventral body midline in the tail region beginning just behind the anus in small larvae but the number decreases to $\sim 15-20$ in postflexion stages. At the posterior end of this ventral row a separate group of distinctive melanophores occurs near the tail tip extending onto the finfold. These melanophores line the base of the caudal fin after it forms. Little pigment is added during the lar-

Table 27.-Meristics from young of Paricelinus hopliticus. (Specimens above dashed line are preflexion, those below are postflexion.)

\begin{tabular}{ccccccccc} 
Body & $\begin{array}{c}\text { Dorsal } \\
\text { fin } \\
\text { length }\end{array}$ & $\begin{array}{c}\text { Dorsal } \\
\text { spines }\end{array}$ & $\begin{array}{c}\text { final } \\
\text { rays }\end{array}$ & $\begin{array}{c}\text { fin } \\
\text { rays }\end{array}$ & $\begin{array}{c}\text { Pectoral } \\
\text { fin rays }\end{array}$ & $\begin{array}{c}\text { Pelvic fin } \\
\text { Left Right } \\
\text { spine } \\
\text { and rays }\end{array}$ & $\begin{array}{c}\text { Preoper- } \\
\text { cular } \\
\text { spines }\end{array}$ & $\begin{array}{c}\text { Ventral } \\
\text { midline } \\
\text { melano- } \\
\text { phores }\end{array}$ \\
\hline 5.6 & - & - & - & - & $N^{1}$ & - & - & 32 \\
6.2 & - & - & - & - & N & - & - & 31 \\
\hline 13.8 & XII & 19 & 23 & 15 & N & I,5 & 4 & 17 \\
18.6 & XII & 19 & 23 & 15 & N & I,5 & 4 & 17 \\
25.6 & XII & 19 & 23 & 15 & N & I,5 & 4 & 19 \\
\hline
\end{tabular}

${ }^{1} \mathrm{~N}=$ Not examined. 
Table 28.-Measurements ( $\mathrm{mm}$ ) of young of Paricelinus hopliticus. (Specimens above dashed line are preflexion, those below are postflexion.)

\begin{tabular}{|c|c|c|c|c|c|c|c|c|}
\hline $\begin{array}{l}\text { Body } \\
\text { length }\end{array}$ & $\begin{array}{l}\text { Head } \\
\text { length }\end{array}$ & $\begin{array}{l}\text { Snout } \\
\text { length }\end{array}$ & $\begin{array}{c}\text { Eye } \\
\text { diameter }\end{array}$ & $\begin{array}{c}\text { Snout to } \\
\text { anus length }\end{array}$ & $\begin{array}{c}\text { Body depth } \\
\text { at pectoral } \\
\text { fin base }\end{array}$ & $\begin{array}{r}\text { Pectoral } \\
\text { fin length }\end{array}$ & $\begin{array}{l}\text { 2d preoper- } \\
\text { cular } \\
\text { spine length }\end{array}$ & $\begin{array}{c}\text { Parietal } \\
\text { spine length }\end{array}$ \\
\hline 5.6 & 1.2 & 0.23 & 0.51 & 2.0 & 0.86 & 0.16 & - & - \\
\hline 6.2 & 1.7 & 0.31 & 0.70 & 2.2 & 1.0 & 0.23 & - & - \\
\hline \multicolumn{9}{|l|}{$-\ldots$} \\
\hline 13.8 & 4.3 & 1.0 & 1.7 & 7.0 & 4.2 & $\mathrm{BR}^{1}$ & $\mathrm{BR}$ & $\mathrm{BR}$ \\
\hline 18.6 & 5.0 & 0.96 & 1.4 & 8.8 & 4.6 & 4.2 & 0.80 & $\sim 0.24$ \\
\hline 25.6 & 8.6 & 2.1 & 2.7 & 11.5 & 5.3 & 7.4 & 0.96 & 0.48 \\
\hline
\end{tabular}

${ }^{1} \mathrm{BR}=$ Broken

val period except over the head and at the base of the pectoral fin. The pelagically captured juvenile has much increased pigmentation in blotches over the entire body and on most fins.

Four spines develop on the preopercular margin in postflexion larvae. A postocular and a nasal spine also become prominent. Spines appear to develop in the parietal and nuchal region and also anteriorly along the parietal ridge. These are difficult to distinguish from the spiny scales that develop dorsally. Similarly, several spines appear to develop in the posttemporal-supracleithral region but are difficult to distinguish from the spiny lateral line scales. Three spine tips (midopercular, subopercular, interopercular) develop along the gill cover margin. A cleithral spine becomes evident in the larger specimens.

Snout to anus length is relatively short in preflexion larvae, $\sim 35-36 \%$ SL but increases with development. Body depth at the pectoral base is also small relative to body length, $\sim 15-16 \%$ SL on preflexion larvae, in-

\section{Paricelinus hopliticus}
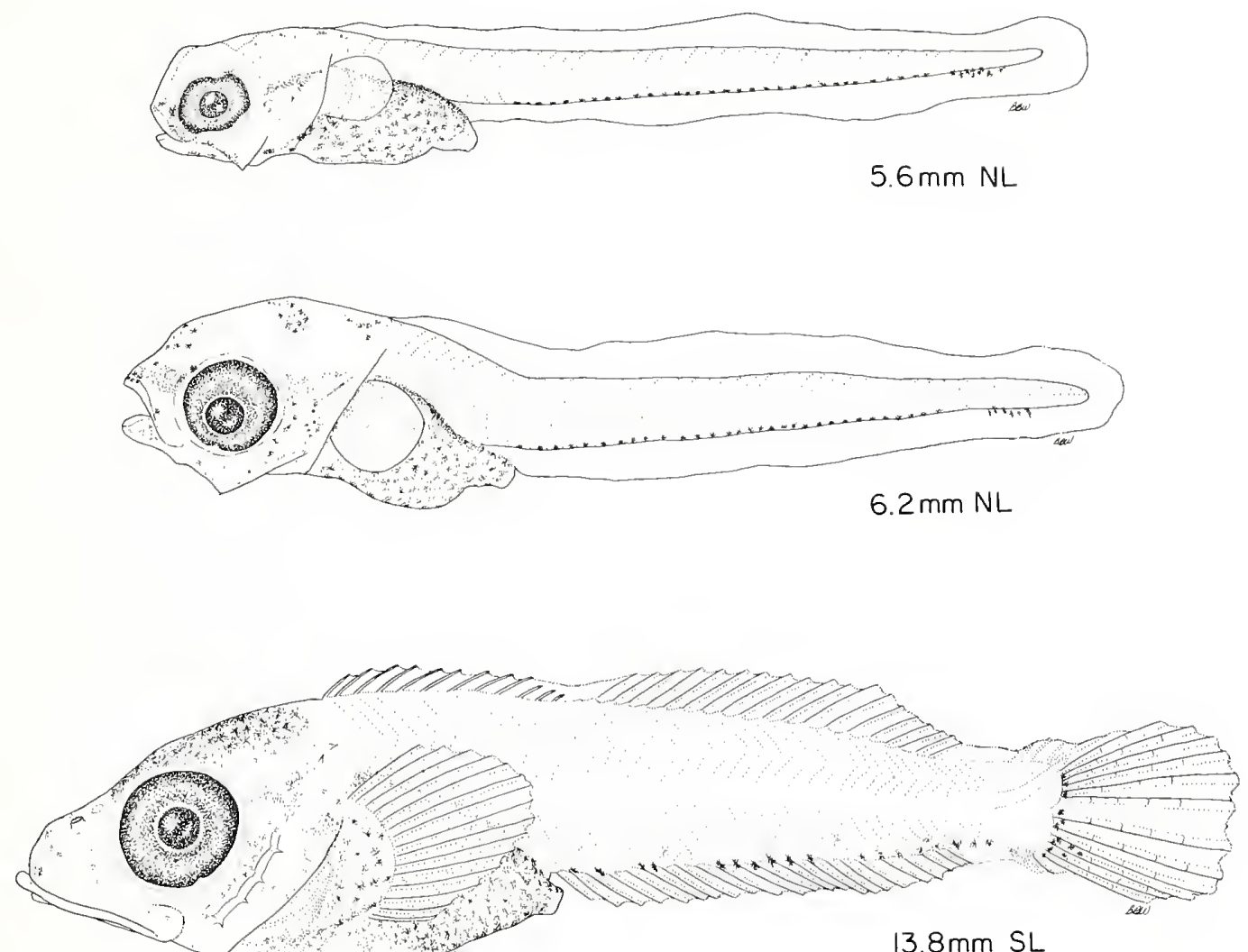

Figure 19.-Larvae of Paricelinus hopliticus. 


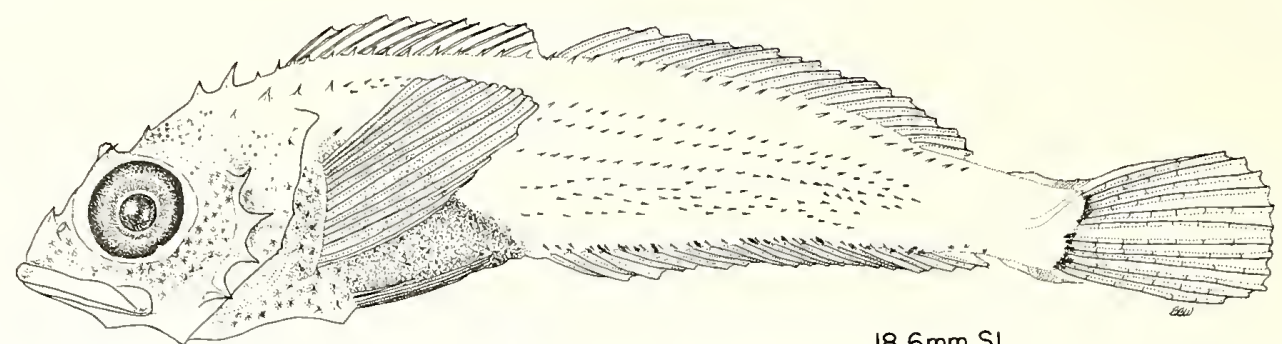

$18.6 \mathrm{~mm} \mathrm{SL}$

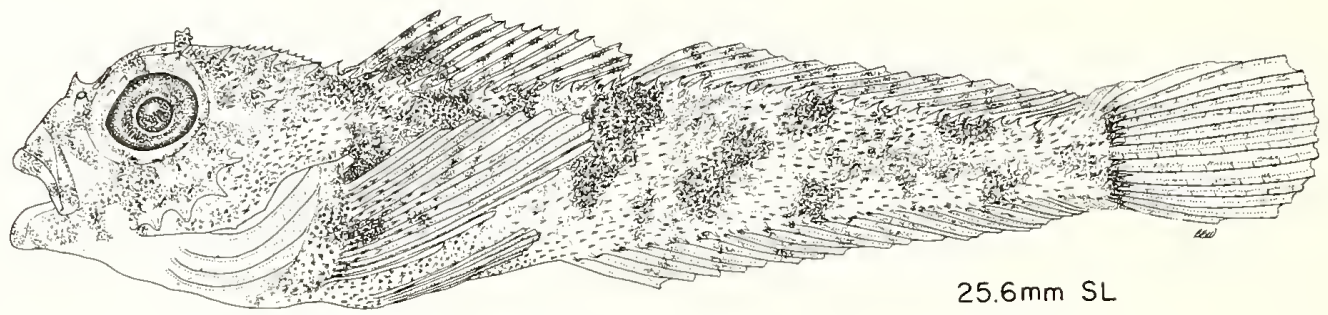

Figure 20.-Young of Paricelinus hopliticus.

creasing to $\sim 25-30 \%$ SL during the larval period then decreasing in the juvenile stage. The general body shape of the larvae resembles that of Icelinus spp. The snout becomes noticeably pointed.

Discussion. Paricelinus is a monotypic genus in the northeast Pacific and its larvae are distinctive. The only other cottid larvae we have encountered with such a heavily pigmented gut are those of our Triglops sp. which lack ventral midline melanophores in the tail region.

\section{Hemilepitodus hemilepidotus ('Tilesius)}

(Figures 21, 22; Tables 29, 30)

Literature. Gorbunova (1964) illustrated (7.25, 10.5 $\mathrm{mm}$ ) and briefly described larvae of $H$. hemilepidotus. In that work, brief descriptions of other hemilepidotine sculpins were also included: Hemilepidotus gilberti (as H. g. gilberti) $(7.5,11.4,17.5 \mathrm{~mm}), H$. jordani $(6.4,10.7$, $13.0 \mathrm{~mm}$ ), and Melletes papilio $(10.7,13.7 \mathrm{~mm})$ with some comments on H. zapus (as $H$. g. zapus). Young of $H$. hemilepidotus, $\sim 20 \mathrm{~mm}$, were described by Peden (1964) who also described young ( $\sim 20 \mathrm{~mm})$ of $H$. jordani, $H$. spinosus, and $H$. zapus. Young of $H$. gilberti (7.1, $11.6,19.2,24.8,32.5 \mathrm{~mm}$ ) were described by Hattori (1964).

Distinguishing Features. Newly hatched, reared larvae are $\sim 5-6 \mathrm{~mm}$ long (Dunn footnote 5) and the smallest larvae in our collections are about that size. By $\sim 19-20$ $\mathrm{mm}$ specimens have adult meristic complements and have acquired a juvenile appearance, although specimens as large as $23 \mathrm{~mm}$ have been captured pelagically

Table 29.-Meristics from young of Hemilepidotus hemilepidotus. (Specimen between dashed lines is undergoing notochord flexion.) [* = Specimen stained with Alizarin Red S; $\mathrm{N}=$ Not examined.]

\begin{tabular}{|c|c|c|c|c|c|c|c|c|c|c|c|c|c|c|c|c|c|c|}
\hline \multirow{4}{*}{$\begin{array}{l}\text { Body } \\
\text { length }\end{array}$} & \multirow{4}{*}{\multicolumn{2}{|c|}{$\frac{\text { Dorsal fin }}{\text { Spines Rays }}$}} & \multirow{4}{*}{$\begin{array}{c}\text { Anal } \\
\text { fin } \\
\text { rays }\end{array}$} & \multirow{3}{*}{\multicolumn{2}{|c|}{$\begin{array}{l}\text { Pectoral } \\
\text { fin rays }\end{array}$}} & \multirow{4}{*}{$\begin{array}{l}\text { Pelvic fin } \\
\text { spine } \\
\text { and rays }\end{array}$} & \multirow{4}{*}{$\begin{array}{c}\text { Preoper- } \\
\text { cular } \\
\text { spines }\end{array}$} & \multirow{4}{*}{$\begin{array}{c}\text { Ventral } \\
\text { midline } \\
\text { melano- } \\
\text { phores }\end{array}$} & \multicolumn{4}{|c|}{ Caudal fin rays } & \multirow{2}{*}{\multicolumn{2}{|c|}{ Vertebrae }} & \multirow{4}{*}{$\begin{array}{c}\text { Branchi- } \\
\text { ostegal } \\
\text { rays }\end{array}$} & \multirow{4}{*}{$\begin{array}{c}\text { Dorsal } \\
\text { scale } \\
\text { rows } \\
\end{array}$} & \multirow{3}{*}{\multicolumn{2}{|c|}{$\begin{array}{c}\begin{array}{c}\text { Scales } \\
\text { above } \\
\text { lateral line }\end{array} \\
\end{array}$}} \\
\hline & & & & & & & & & \multicolumn{2}{|c|}{ Dorsal } & \multicolumn{2}{|c|}{ Ventral } & & & & & & \\
\hline & & & & & & & & & Second- & Prin- & Prin- & Second- & \multirow{2}{*}{$\begin{array}{c}\text { Abdom- } \\
\text { inal }\end{array}$} & \multirow{2}{*}{$\begin{array}{c}\text { Cau- } \\
\text { dal }\end{array}$} & & & & \\
\hline & & & & Left & Right & & & & ary & cipal & cipal & ary & & & & & Left & Right \\
\hline 5.8 & - & - & - & - & $\mathrm{N}$ & - & - & 14 & $\mathrm{~N}$ & $\mathrm{~N}$ & $\mathrm{~N}$ & $\mathrm{~N}$ & $\mathrm{~N}$ & $\mathrm{~N}$ & $\mathrm{~N}$ & - & - & $\mathrm{N}$ \\
\hline 5.9 & - & - & - & - & $\mathrm{N}$ & - & - & 14 & $\mathrm{~N}$ & $\mathrm{~N}$ & $\mathrm{~N}$ & $\mathrm{~N}$ & $\mathrm{~N}$ & $\mathrm{~N}$ & $\mathrm{~N}$ & - & - & $\mathrm{N}$ \\
\hline 9.1 & - & - & - & - & $\mathrm{N}$ & - & 2 & 9 & $\mathrm{~N}$ & $\mathrm{~N}$ & $\mathrm{~N}$ & $\mathrm{~N}$ & $\mathrm{~N}$ & $\mathrm{~N}$ & $\mathrm{~N}$ & - & - & $\mathrm{N}$ \\
\hline 10.7 & IX & 19 & 15 & 17 & $\mathrm{~N}$ & Buds & 4 & 11 & $\mathrm{~N}$ & $\mathrm{~N}$ & $\mathrm{~N}$ & $\mathrm{~N}$ & $\mathrm{~N}$ & $\mathrm{~N}$ & $\mathrm{~N}$ & - & - & $\mathrm{N}$ \\
\hline $11.4^{*}$ & - & 17 & 12 & 13 & 13 & Buds & 4 & $\mathrm{~N}$ & - & 6 & 6 & - & 12 & 19 & 6 & - & - & - \\
\hline 11.5 & $\mathrm{XI}$ & 18 & 15 & 17 & $\mathrm{~N}$ & Buds & 4 & 7 & $\mathrm{~N}$ & $\mathrm{~N}$ & $\mathrm{~N}$ & $\mathrm{~N}$ & $\mathrm{~N}$ & $\mathrm{~N}$ & $\mathrm{~N}$ & - & - & $\mathrm{N}$ \\
\hline 19.0 & $\mathrm{XI}$ & 20 & 16 & 16 & 16 & $\mathrm{I}, 4$ & 4 & 2 & $\mathrm{~N}$ & $\mathrm{~N}$ & $\mathrm{~N}$ & $\mathrm{~N}$ & $\mathrm{~N}$ & $\mathrm{~N}$ & $\mathrm{~N}$ & 4 & 19 & $\mathrm{~N}$ \\
\hline $23.0^{*}$ & $\mathrm{XI}$ & 19 & 17 & 16 & 16 & $\mathrm{I}, 4$ & 4 & $\mathrm{~N}$ & 7 & 6 & 6 & 6 & 12 & 24 & 6 & 5 & 27 & 23 \\
\hline
\end{tabular}


at the surface. Thus there may be a pelagic juvenile phase similar to that of rockfishes, Sebastes spp. The smallest transformed specimen collected in Oregon tidepools was $21 \mathrm{~mm} \mathrm{SL}$. In our collection we have no specimens between $\sim 11.5$ and $19 \mathrm{~mm}$.

Newly hatched larvae have pigment on the head and along the dorsal midline of the body extending to all but the posterior $3 \mathrm{~d}$ or 4 th myomere. An unpigmented area occurs on the dorsal midline between about myomeres 411 which fills in with pigment by $\sim 6-7 \mathrm{~mm}$. The dorsolateral surface of the gut is moderately pigmented. A series of melanophores extends along the ventral midline beginning at about the 9 th or 10th postanal myomere extending to all but the last 3 or 4 myomeres. Melanophores in this series usually number $<15$. With development, melanophores are added over the head, anterodorsal body surface, and the gut. Some internal melanophores appear to extend dorsally from the ventral midline melanophores in larvae as small as $6 \mathrm{~mm}$. Additional internal melanophores appear ventrolaterally between the notochord and ventral midline. By 9 $\mathrm{mm}$, internal melanophores can be seen in a row above

Hemilepidotus hemilepidotus
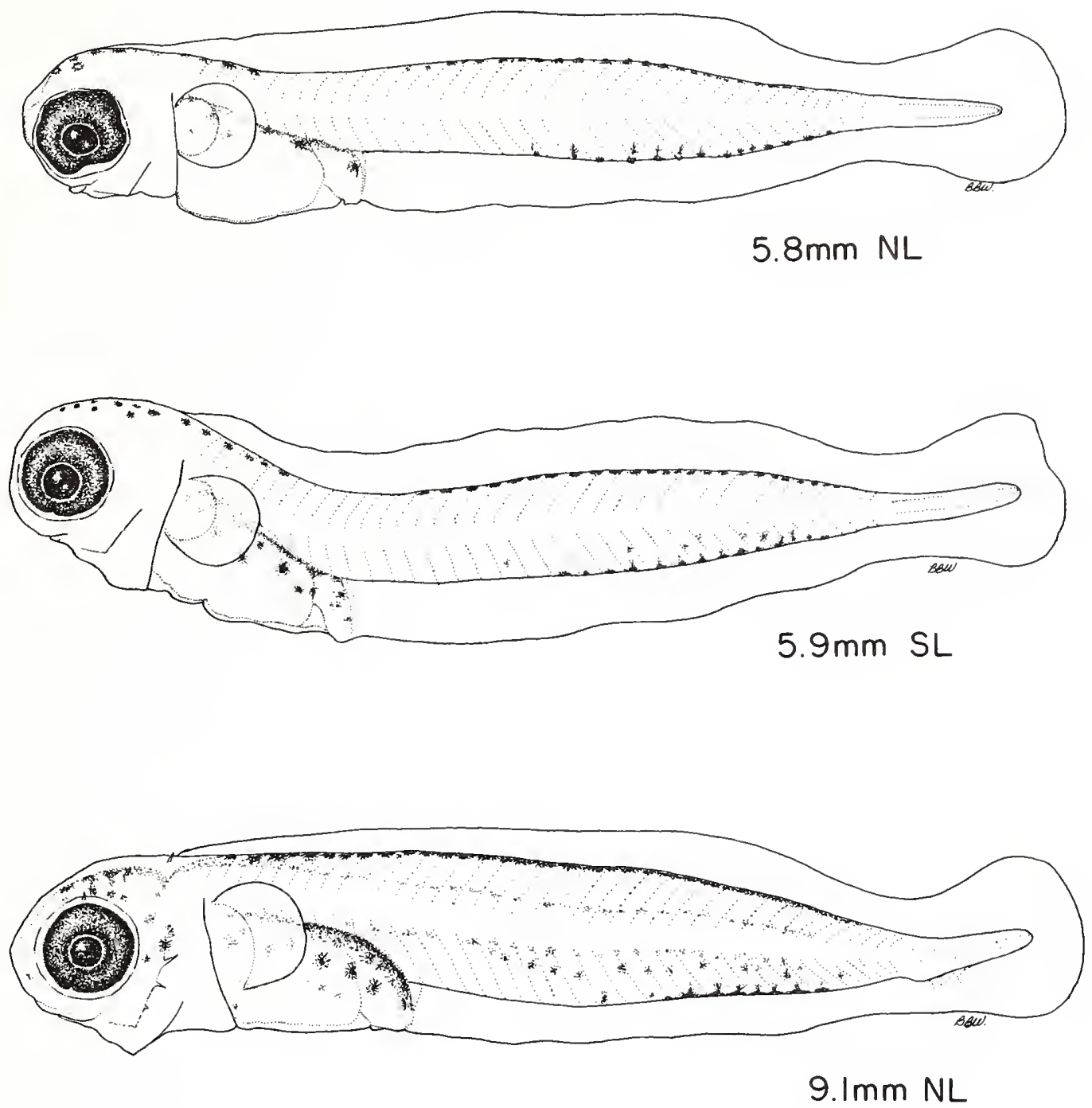

Figure 21.-Larvae of Hemilepidotus hemilepidotus. 
Table 30.-Measurements ( $\mathrm{mm}$ ) of young of Hemilepidotus hemilepidotus. (Specimen between dashed lines is undergoing notochord flexion.)

\begin{tabular}{|c|c|c|c|c|c|c|c|c|}
\hline $\begin{array}{l}\text { Body } \\
\text { length }\end{array}$ & $\begin{array}{l}\text { Head } \\
\text { length }\end{array}$ & $\begin{array}{l}\text { Snout } \\
\text { length }\end{array}$ & $\begin{array}{c}\text { Eye } \\
\text { diameter }\end{array}$ & $\begin{array}{c}\text { Snout to } \\
\text { anus length }\end{array}$ & $\begin{array}{c}\text { Body depth } \\
\text { at pectoral } \\
\text { fin base } \\
\end{array}$ & $\begin{array}{r}\text { Pectoral } \\
\text { fin length }\end{array}$ & $\begin{array}{l}\text { 2d preoper- } \\
\text { cular } \\
\text { spine length }\end{array}$ & $\begin{array}{c}\text { Parietal } \\
\text { spine length }\end{array}$ \\
\hline 5.8 & 0.90 & 0.06 & 0.52 & 2.0 & 1.0 & 0.32 & - & - \\
\hline 5.9 & 1.0 & 0.27 & 0.58 & 2.1 & 0.86 & 0.34 & - & - \\
\hline 9.1 & 2.0 & 0.27 & 0.9 & 3.4 & 1.7 & 0.62 & 0.22 & 0.10 \\
\hline 10.7 & 2.7 & 0.47 & 1.2 & 4.6 & 2.6 & 1.1 & 0.39 & 0.27 \\
\hline 11.5 & 3.7 & 0.96 & 1.3 & 6.4 & 3.3 & 1.7 & 0.51 & $\mathrm{BR}^{1}$ \\
\hline 19.0 & 6.7 & 1.28 & 2.2 & 11.0 & 6.0 & 4.0 & 0.9 & 0.31 \\
\hline
\end{tabular}

${ }^{1} \mathrm{BR}=$ Broken

\section{Hemilepidotus hemilepidotus}

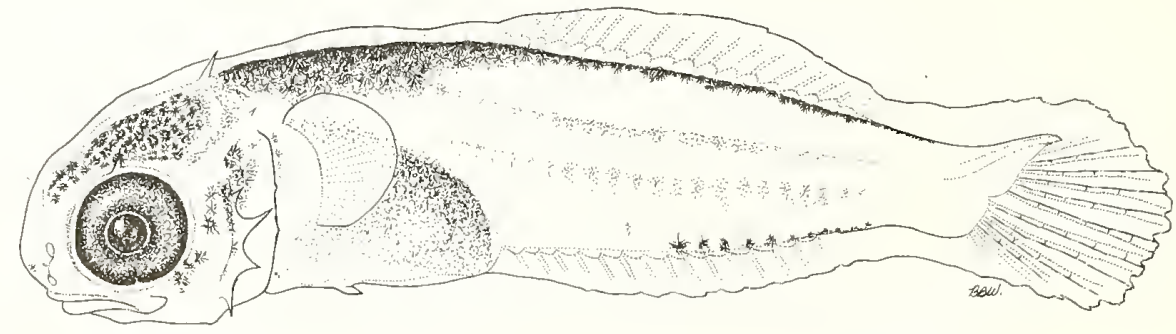

$10.7 \mathrm{~mm} \mathrm{SL}$
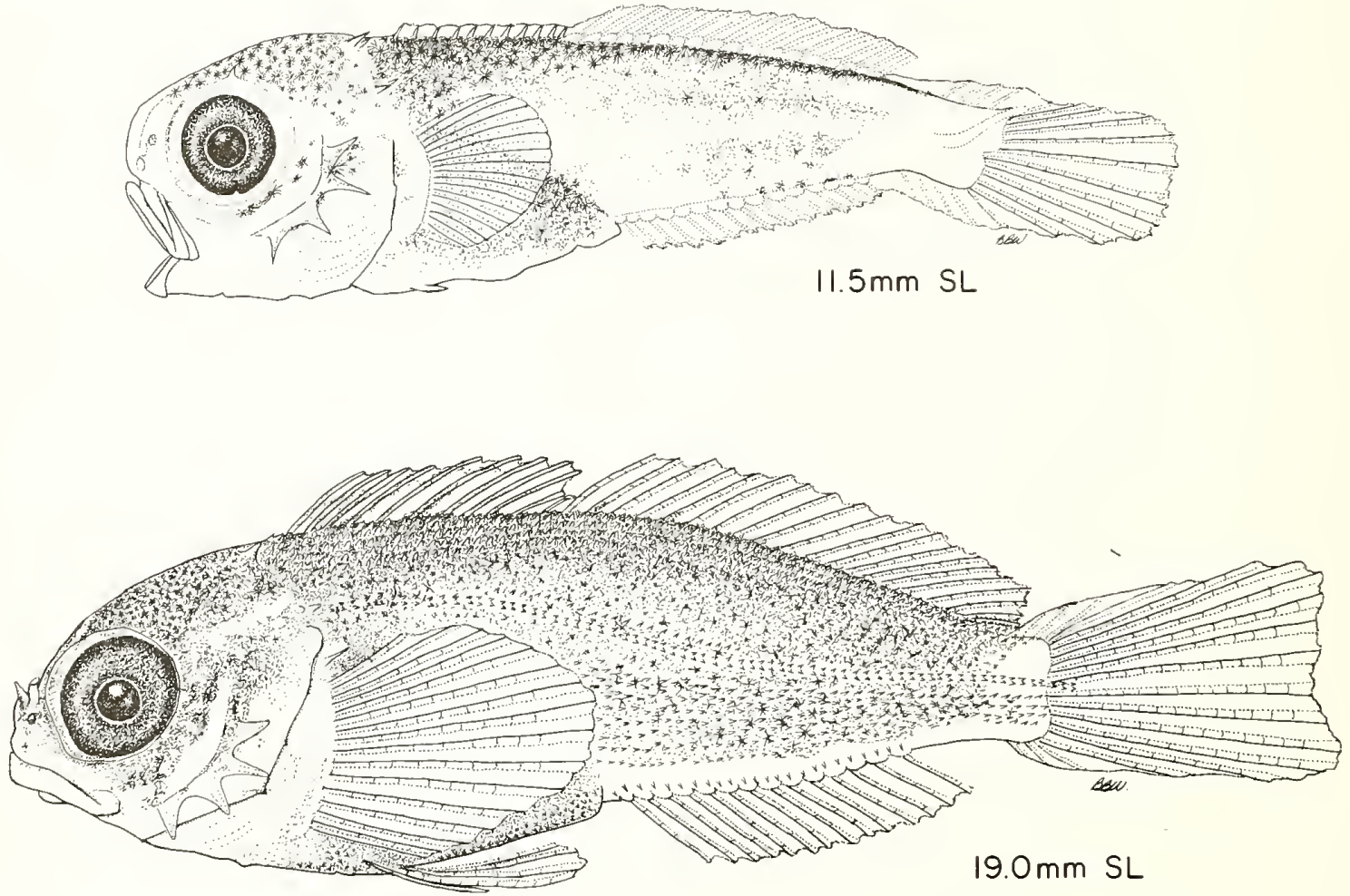

Figure 22.-Young of Hemilepidotus hemilepidotus. 
and below the notochord along much of the body. These internal melanophores remain visible until the lateral musculature obscures them. External melanophores are not added laterally until larvae are $>11 \mathrm{~mm}$, and then as a relatively light scattering compared to $H$. spinosus. The ventral midline melanophores gradually become internal but remain visible through the skin and serve as a diagnostic character to distinguish them from $H$. spinosus until dorsal scale rows develop (see Discussion). By $19 \mathrm{~mm}$ the entire body except the caudal peduncle and ventral body margin are covered with pigment which is darker dorsally and lighter below.

Four prominent spines develop on the preopercle, some of which are visible by $9 \mathrm{~mm}$. A parietal spine can be seen at $\sim 9 \mathrm{~mm}$ and later a nuchal spine, the two fusing together late in the larval period. A postocular spine develops over the eye $\sim 9 \mathrm{~mm}$ and remains obvious at least until $11 \mathrm{~mm}$, probably disappearing during transformation. This spine develops only as a minute spinule for a brief period, $\sim 8-9.3 \mathrm{~mm}$ in $H$. spinosus, barely visible without staining. With development three spines appear in the posttemporal-supracleithral region, being reduced to bumps in larger specimens. A cleithral spine is apparent by $\sim 19-20 \mathrm{~mm}$. A nasal spine develops on the snout. Tips of 3 spines (midopercular, interopercular, subopercular) can be seen on the margin of the gill cover by $\sim 11 \mathrm{~mm}$.

Relative body depth increases with development from $\sim 15-18$ to $32 \%$ SL as does snout to anus distance from $\sim 35$ to $58 \%$. Pectoral fin length increases to $\sim 21 \%$ SL by $19 \mathrm{~mm}$. Adult complements of fin rays, dorsal scale rows, and scales above the lateral line are countable in the 19 $\mathrm{mm}$ specimen and probably in smaller specimens based on $H$. spinosus in which adult complements are attained by $\sim 14 \mathrm{~mm}$. Gill membranes are noticeably free from the isthmus in the $19 \mathrm{~mm}$ specimen.

Discussion. The relative position of the first postanal ventral midline melanophore and the posterior extent of the ventral series serve as excellent diagnostic characters to separate larvae of $H$. hemilepidotus from $H$. spinosus until the dorsal scale rows are formed. In H. hemilepidotus the ventral midline melanophore series begins at about the 9 th or 10 th postanal myomere and consists of usually $<15$ melanophores. In $H$. spinosus this ventral row begins immediately behind the anus and consists of usually $>15$ melanophores in all but the largest specimens. In larger specimens, the number of dorsal scale rows separate the two species, 4 or 5 in $H$. hemilepidotus and 6-8 in H. spinosus. These can be counted in specimens as small as $14 \mathrm{~mm}$.

The placement and number of ventral midline melanophores may not serve to distinguish $H$. hemilepidotus from other species, e.g., $H$. gilberti, $H$. jordani, and $H$. zapus, based on Gorbunova's (1964) and Hattori's (1964) descriptions. All four species reportedly have the same ventral midline melanophore pattern. And small larvae of all four reportedly have an unpigmented break in the dorsal midline melanophore series which fills in with development. Additional characters given by Gorbunova do not appear to be adequate to distinguish larvae among these four species. One character used by Gorbunova to distinguish late larvae of $H$. gilberti, i.e., presence of a row of scales above the anal fin, is invalid. We have observed such scales in $H$. spinosus and $H$. hemilepidotus, and Peden (1964) has shown them in young of $H$. jordani and $H$. zapus. These become overgrown on larger fish. Gorbunova stated that larvae of $H$. gilberti develop 5 preopercular spines which would help distinguish them but this is probably an error in observation, based on our knowledge of other cottid larvae and illustrations by Hattori. Pigment patterns as reported by Gorbunova seem inadequate to distinguish species. Closer attention to detail in exact numbers of ventral melanophores and their placement with respect to myomere number together with a more detailed examination of external lateral pigment and internal pigment along the notochord may help resolve the problems of larval identification. Meristic and morphometric characters as discussed by Peden will be useful in identifying larger specimens, $>18-20 \mathrm{~mm}$. Relative body proportions may also be of some help but these must be better defined to evaluate their usefulness in young specimens.

Larvae $(10.7,13.7 \mathrm{~mm})$ of another hemilepidotine sculpin from the Bering sea, Melletes papilio, as described by Gorbunova (1964) are easily distinguished by the extension of the dorsal and ventral midline melanophores onto and around the urostyle.

See also Discussion under $H$. spinosus.

\section{Hemilepidotus spinosus (Ayres)}

(Figures 23, 24; Tables 31, 32)

Literature. Follett (1952) illustrated (12, $21 \mathrm{~mm}$ SL) and briefly described several specimens of $H$. spinosus which we confirm. Peden (1964) also discussed young $(\sim 20 \mathrm{~mm})$ of this species. (See also Literature section under H. hemilepidotus.)

Distinguishing Features. The smallest larvae in our collections are $\sim 5 \mathrm{~mm}$ and appear to be recently hatched. Specimens as large as $27 \mathrm{~mm}$ have been captured pelagically although most juvenile characteristics appear to be present by $\sim 19-20 \mathrm{~mm}$.

The smallest larvae examined, $\sim 5 \mathrm{~mm}$, have pigment on the head and in a continuous line on the dorsal body margin from the head to the posteriormost myomere. Some pigment occurs on the dorsolateral surface of the gut. A row of $>15$ melanophores extends along the ventral body midline from immediately behind the anus to the posteriormost myomere. A single melanophore is usually apparent posterior to this line about midway to the notochord tip. This melanophore later appears on the midcaudal fin base between the upper and lower hypural elements. With development external melanophores are added on the head, over the gut and laterally in $H$. spinosus larvae as small as $6 \mathrm{~mm}$ in contrast to $H$. hemilepidotus. By $8-9 \mathrm{~mm}$, internal pigment is noticeable in a line above the notochord along most of the 

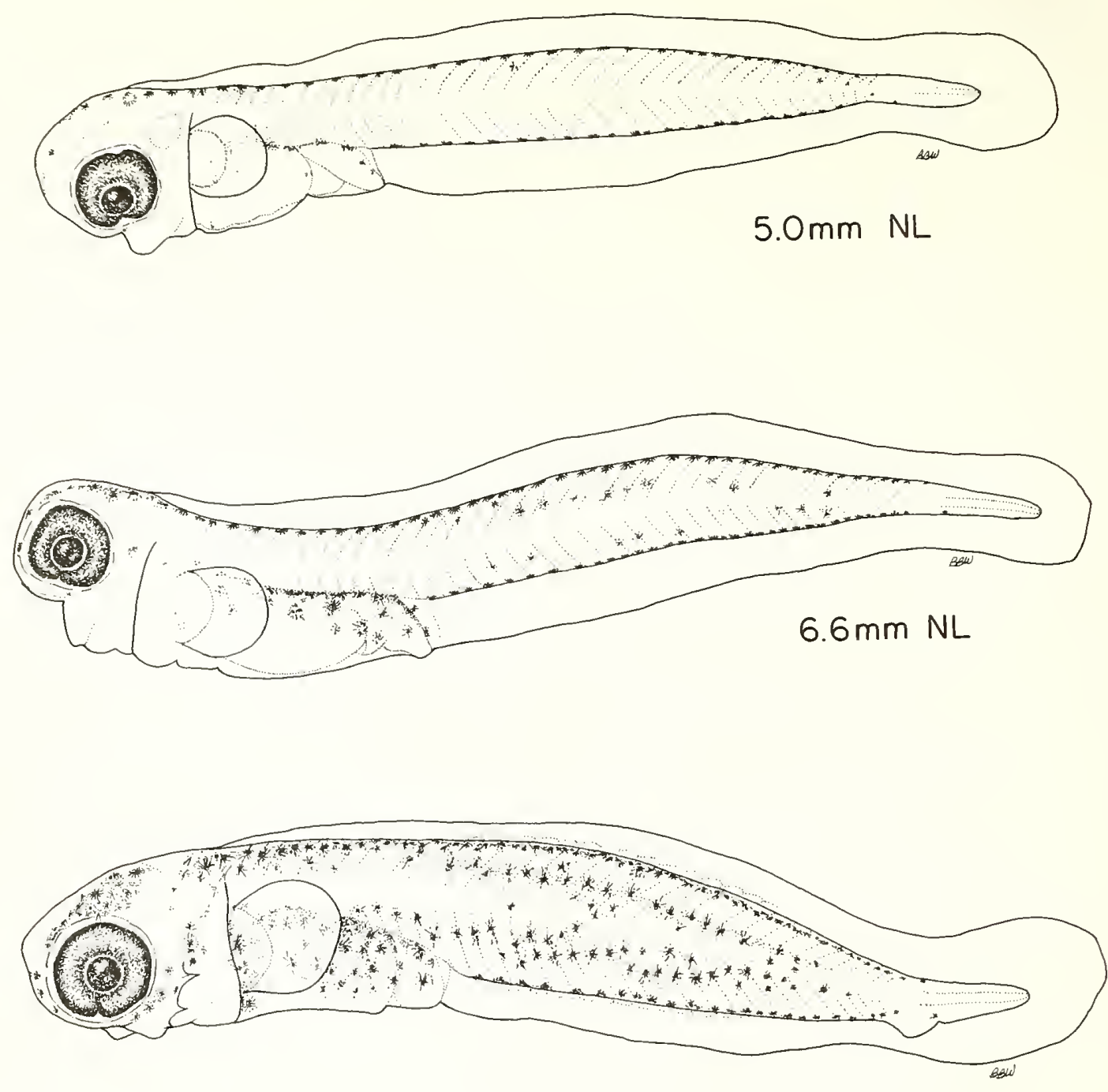

$8.9 \mathrm{~mm} \mathrm{NL}$

Figure 23.-Larvae of Hemilepidotus spinosus.

body. Internal pigment never becomes obvious below the notochord as in $H$. hemilepidotus, possibly because of thicker musculature or because the more intense external lateral melanophores obscure it. Pigment increases over the dorsal body surface first anteriorly in the nape region then posteriorly extending laterally until most of the body is pigmented, except ventrally and on the caudal peduncle, by $\sim 19-20 \mathrm{~mm}$. The ventral midline melanophores become embedded but remain visible through the skin at least to $\sim 14 \mathrm{~mm}$, which serve to distinguish these larvae from $H$. hemilepidotus.
Four preopercular spines develop, beginning $\sim 7 \mathrm{~mm}$. A parietal spine can be seen $\sim 7 \mathrm{~mm}$ and later a nuchal spine develops posterior to it fusing with it in the largest specimens. A minute postocular spine develops over the eye in larvae $8.0-9.3 \mathrm{~mm}$ and then disappears. This spine never becomes prominent as in $H$. hemilepidotus and is barely visible without staining. Three spines develop in the posttemporal-supracleithral region but become reduced to bumps. A nasal spine and a cleithral spine are present by $19 \mathrm{~mm}$. Three spine tips (midopercular, sub- 

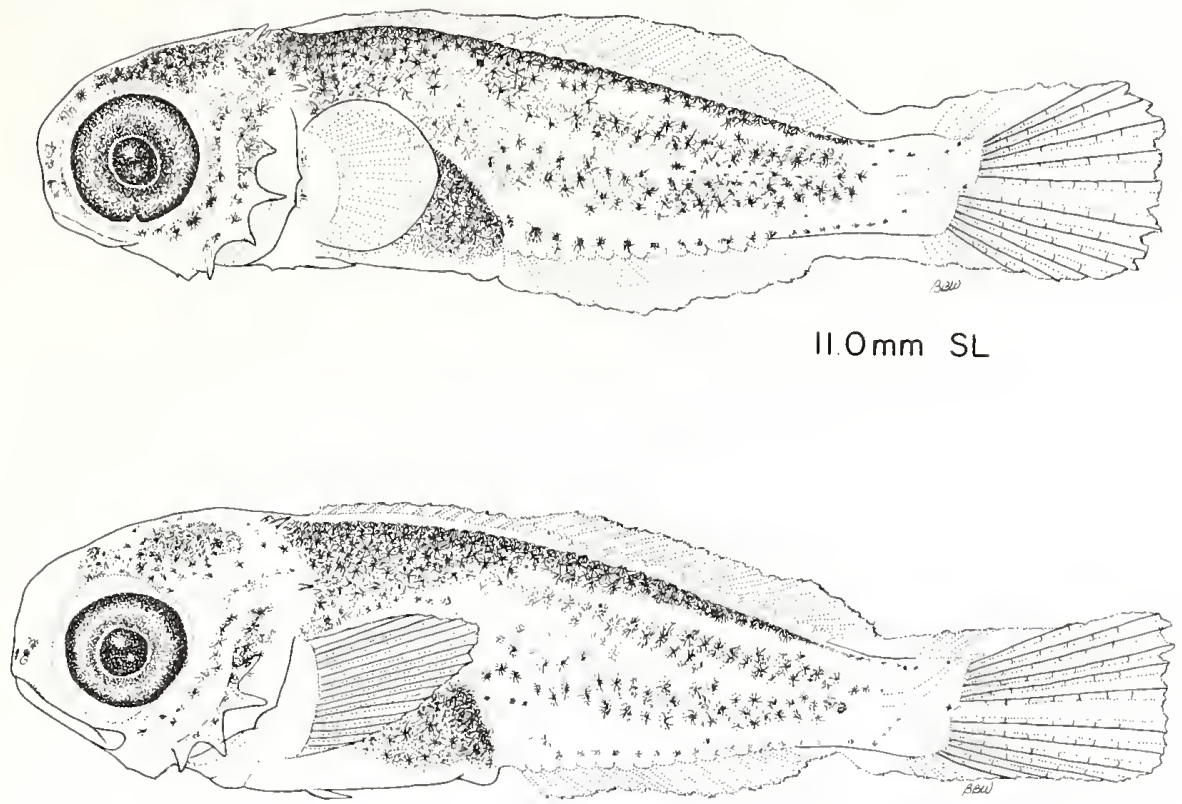

$11.8 \mathrm{~mm} \mathrm{SL}$

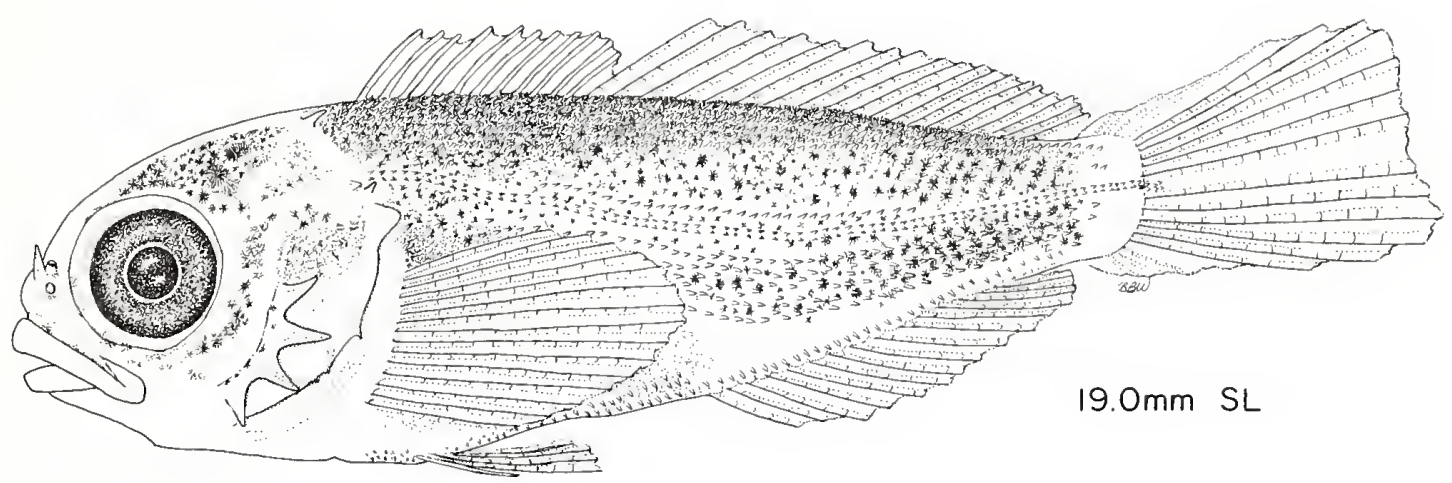

Figure 24.-Young of Hemilepidotus spinosus.

opercular, interopercular) are visible on the gill cover margin by $\sim 11-12 \mathrm{~mm}$.

Body depth increases from $\sim 15-16 \%$ to $\sim 32-34 \%$ SL with development as does snout to anus distance, $38-39 \%$ to $60-61 \% \mathrm{SL}$. Pectoral fin length increases to $\sim 26 \% \mathrm{SL}$ by $19-20 \mathrm{~mm}$. Adult complements of fin rays, dorsal scale rows, and scales above the lateral line are present by $\sim 14$ $\mathrm{mm}$. In $19-20 \mathrm{~mm}$ specimens the gill membranes are noticeably attached to the isthmus.

Discussion. Early life history strategies appear to differ between $H$. spinosus and $H$. hemilepidotus. Larvae of $H$. spinosus are much more abundant in our plankton samples than $H$. hemilepidotus and they have been collected farther offshore, as far as $111 \mathrm{~km}$ from the coast. We have

taken late larvae-early juvenile stages of both species in neuston collections but $H$. spinosus is much more common. Collections in Oregon tidepools have yielded primarily young juveniles of $H$. hemilepidotus and only

rarely $H$. spinosus. Our data indicate that $H$. hemilepidotus generally spawns closer to shore and the larvae are not as neustonic as $H$. spinosus. Tidepools may be important nursery areas for juvenile $H$. hemilepidotus whereas 
Table 31.-Meristics from young of Hemilepidotus spinosus. (Specimen between dashed lines is undergoing notochord flexion.) $\left[{ }^{*}=\right.$ Specimens stained with Alizarin Red $\mathrm{S} ;{ }^{* *}=$ Dorsal fin spines and soft rays cannot be distinguished; $\mathrm{B}=$ Bases only; $\mathrm{N}=$ Not examined.]

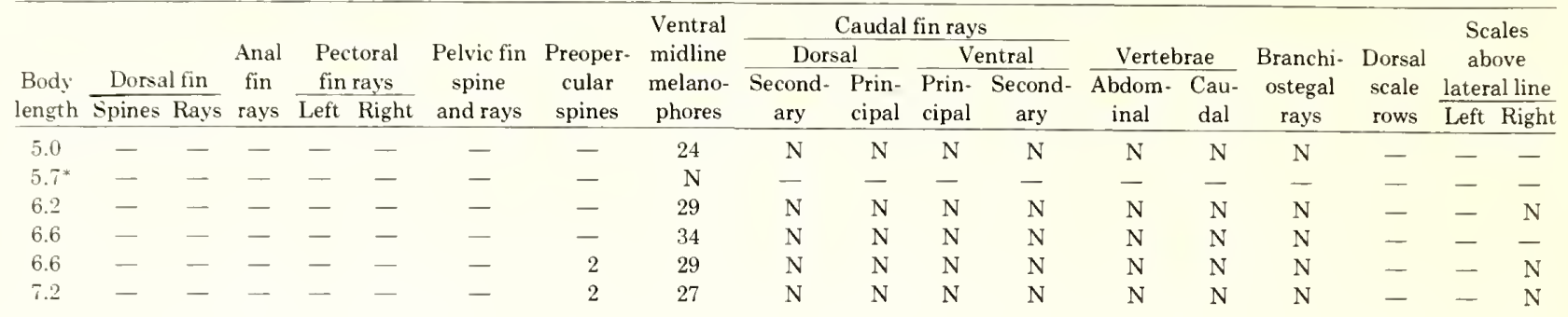

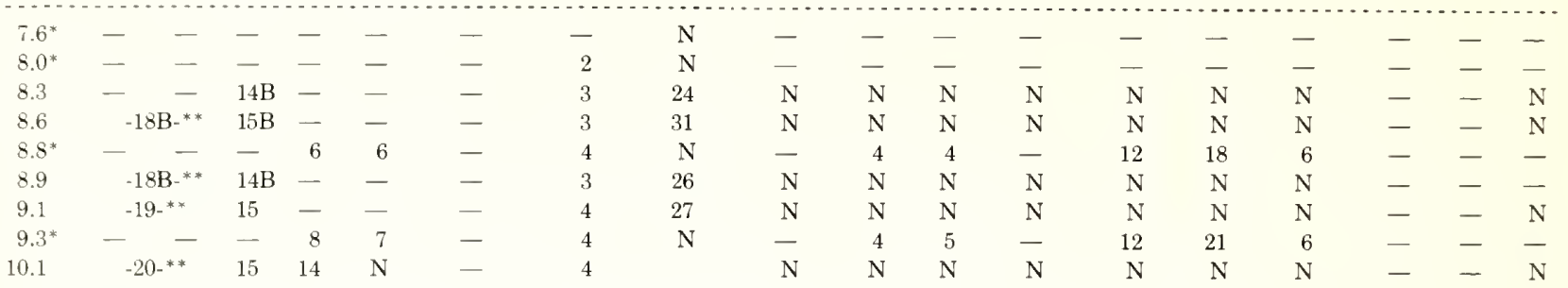

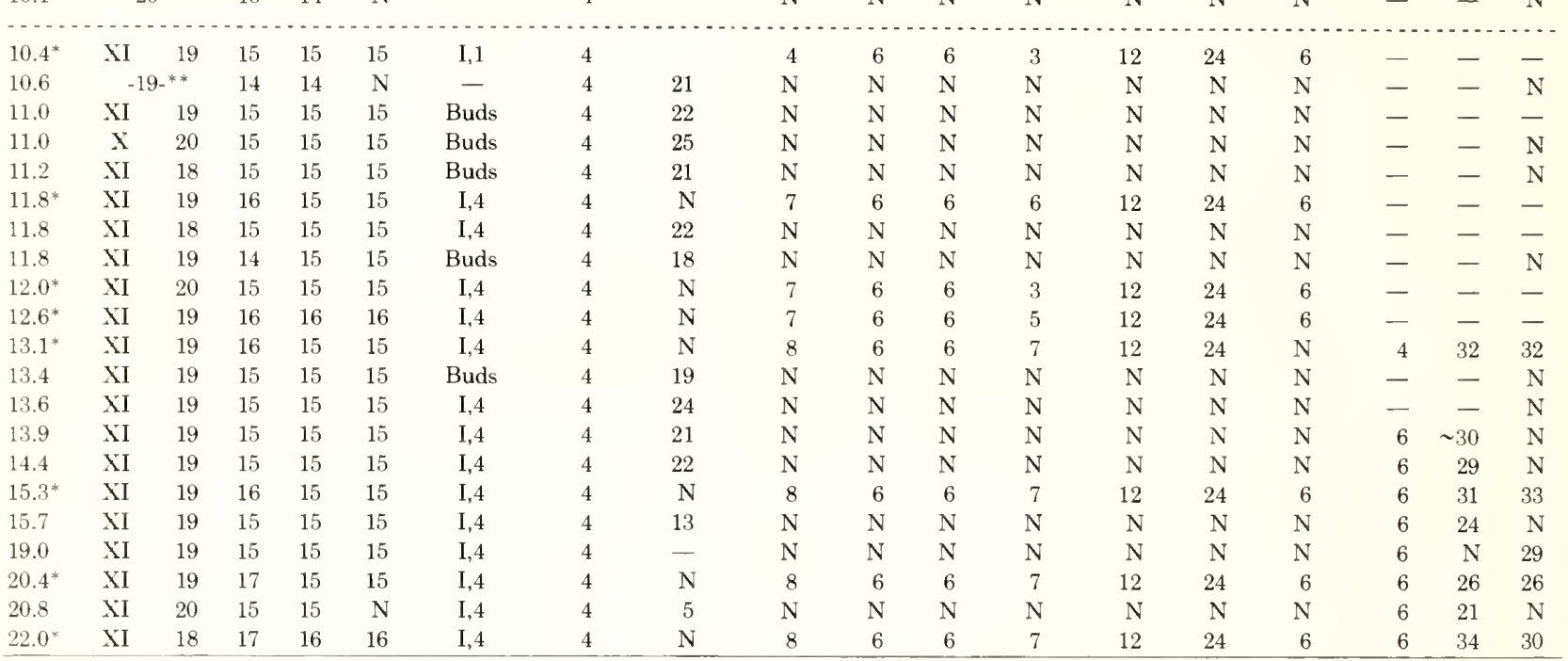

juvenile $H$. spinosus utilize different areas, perhaps farther offshore, as nurseries.

\section{Nautichthys oculofasciatus (Girard)}

(Figure 25; Tables 33, 34)

Literature. Larvae of this species were illustrated (7.5, $13 \mathrm{~mm} \mathrm{SL}$ ) and briefly described by Blackburn (1973) and young stages $(9.5,13,17,26 \mathrm{~mm}$ TL) by Marliave (1975).

Distinguishing Features. Larvae hatch at a relatively large size, probably $\sim 7 \mathrm{~mm}$ SL. The largest pelagic specimens reported are $\sim 16-17 \mathrm{~mm}$ in which all fins are developed except the pelvics. A transformed juvenile, 26 $\mathrm{mm}$ TL, was taken in a benthic habitat (Marliave 1975) indicating transformation probably occurs between these sizes.

The larvae are distinctively pigmented over the lateral surface of the body, except for the caudal peduncle, with melanophores extending onto the dorsal and anal finfolds and fins in the middle of the tail region. Melanophores also occur over the head, at the base of the pectoral fin, on the pectoral fin rays as a band near the fin margin, and over the dorsolateral surface of the gut. Pigment is added to the spinous dorsal fin as the anterior rays become elongate.

Four spines develop on the preopercle appearing as bumps. Enlarged bumps also develop in the parietal region, anterior to it along the parietal ridge, in the postocular region, nasal region, and several in the posttemporal-supracleithral area. None of these appear as pronounced sharp spines.

The length of the pelvic fins is striking, 42 and $59 \% \mathrm{SL}$ in our two specimens. Snout to anus length is relatively long, 56 and $51 \%$ SL while body depth at the pectoral fin base is relatively slender, 21 and $23 \%$ SL. The number of myomeres $(>40)$ is relatively high for a cottid. The larvae have an agonidlike appearance.

Discussion. Only one species of Nautichthys occurs off 
Table 32.-Measurements ( $\mathrm{mm}$ ) of young of Hemilepidotus spinosus. (Specimens between dashed lines are undergoing notochord flexion.)

\begin{tabular}{|c|c|c|c|c|c|c|c|c|}
\hline $\begin{array}{l}\text { Body } \\
\text { length }\end{array}$ & $\begin{array}{c}\text { Head } \\
\text { length }\end{array}$ & $\begin{array}{l}\text { Snout } \\
\text { length }\end{array}$ & $\begin{array}{c}\text { Eye } \\
\text { diameter } \\
\end{array}$ & $\begin{array}{c}\text { Snout to } \\
\text { anus length }\end{array}$ & $\begin{array}{c}\text { Body depth } \\
\text { at pectoral } \\
\text { fin base } \\
\end{array}$ & $\begin{array}{r}\text { Pectoral } \\
\text { fin length }\end{array}$ & $\begin{array}{l}\text { 2d preoper- } \\
\text { cular } \\
\text { spine length }\end{array}$ & $\begin{array}{c}\text { Parietal } \\
\text { spine length }\end{array}$ \\
\hline 5.0 & 0.88 & 0.12 & 0.46 & 1.9 & 0.82 & 0.24 & - & - \\
\hline 6.2 & 1.1 & 0.16 & 0.56 & 2.6 & 0.94 & 0.31 & - & - \\
\hline 6.6 & 1.0 & 0.24 & 0.54 & 2.5 & 0.98 & 0.35 & - & - \\
\hline 6.6 & 1.4 & 0.24 & 0.56 & 2.6 & 1.0 & 0.47 & - & 0.04 \\
\hline 7.2 & 1.4 & 0.31 & 0.62 & 2.8 & 1.2 & 0.47 & - & 0.04 \\
\hline 8.3 & 1.9 & 0.39 & 0.82 & 3.6 & 1.6 & 0.47 & 0.24 & 0.10 \\
\hline 8.6 & 1.6 & 0.35 & 0.78 & 3.5 & 1.5 & 0.66 & 0.22 & 0.12 \\
\hline 8.9 & 1.7 & 0.23 & 0.82 & 3.5 & 1.7 & 0.74 & 0.27 & 0.20 \\
\hline 9.1 & 1.9 & 0.39 & 0.90 & 3.8 & 1.8 & 0.78 & 0.27 & 0.20 \\
\hline 10.1 & 2.3 & 0.40 & 1.2 & 3.9 & 2.0 & 0.82 & 0.39 & 0.23 \\
\hline 10.6 & 2.5 & 0.39 & 1.2 & 4.5 & 2.1 & 0.82 & 0.35 & 0.31 \\
\hline 11.0 & 3.1 & 0.39 & 1.3 & 5.4 & 2.7 & 1.5 & 0.58 & 0.23 \\
\hline 11.0 & 3.1 & 0.48 & 1.3 & 5.5 & 3.0 & 1.5 & 0.70 & $\sim 0.27$ \\
\hline 11.2 & 3.3 & 0.40 & 1.6 & 5.5 & 3.0 & 1.6 & 0.66 & 0.31 \\
\hline 11.8 & 3.8 & 0.70 & 1.4 & 6.2 & 3.4 & 1.8 & 0.72 & 0.24 \\
\hline 11.8 & 3.8 & 0.80 & 1.6 & 6.7 & 3.4 & 1.9 & 0.78 & 0.31 \\
\hline 13.4 & 4.7 & 0.96 & 1.9 & 7.0 & 4.2 & 2.4 & 0.88 & $\sim 0.2$ \\
\hline 13.6 & 4.6 & 0.96 & 2.0 & 7.4 & 4.2 & 2.7 & 0.88 & - \\
\hline 13.9 & 5.1 & 1.0 & 1.8 & 7.4 & 4.3 & 2.9 & 0.9 & - \\
\hline 14.4 & 5.4 & 1.0 & 1.8 & 8.2 & 5.0 & 2.9 & $\mathrm{BR}^{1}$ & - \\
\hline 15.7 & 5.7 & 1.4 & 2.0 & 9.3 & 5.0 & 3.4 & 1.1 & - \\
\hline 19.0 & 7.4 & 1.7 & 2.2 & 11.5 & 6.4 & 4.8 & 1.1 & - \\
\hline 20.8 & 7.8 & 2.2 & 2.2 & 12.5 & 6.6 & 5.4 & 1.1 & - \\
\hline
\end{tabular}

${ }^{1} \mathrm{BR}=$ Broken.

\section{Nautichthys oculofasciatus}

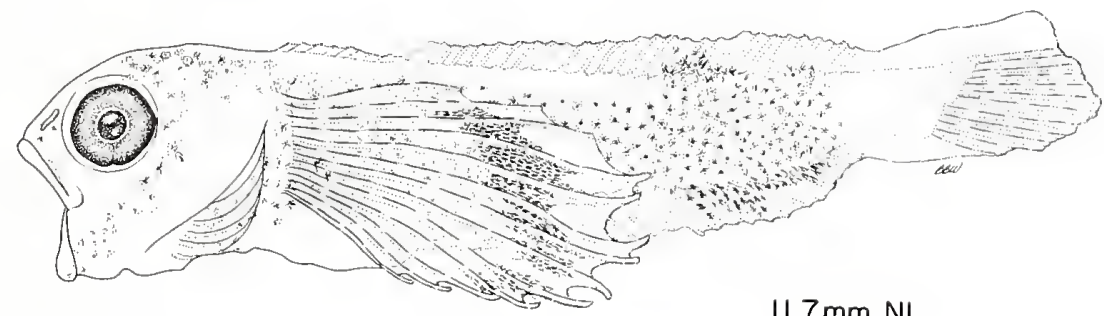

$11.7 \mathrm{~mm} \mathrm{NL}$

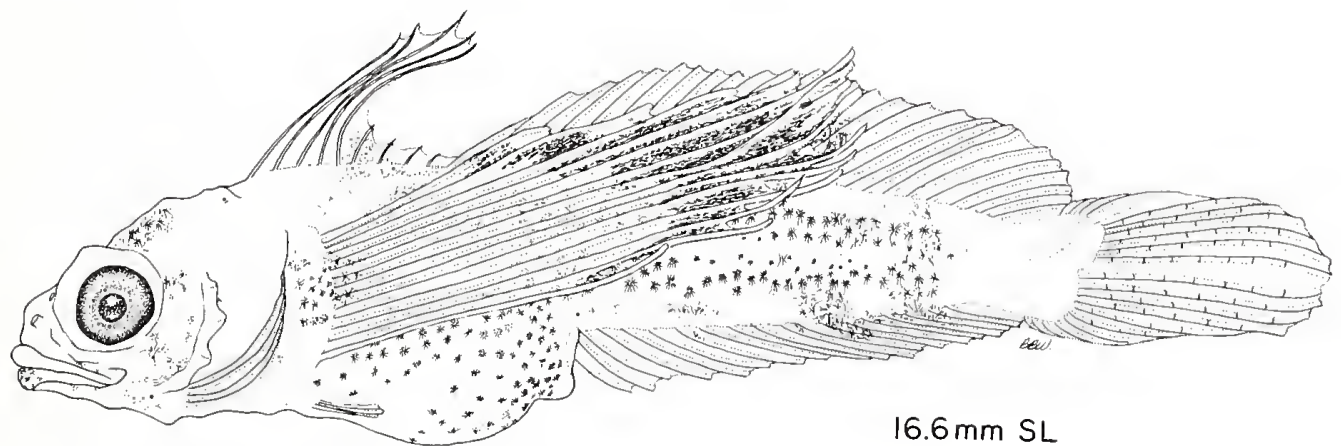

Figure 25.-Larvae of Nautichthys oculofasciatus 
Oregon and the larvae are striking in appearance. The larvae are rare in our collections. Only two specimens have been taken, both $9 \mathrm{~km}$ off Newport, Oreg., in March. Larvae of two additional northeast species $N$. pribilovius and $N$. robustus are unknown.

Table 33.-Meristics from larvae of Nautichthys oculofasciatus. (Specimen above dashed line is undergoing notochord flexion.)

\begin{tabular}{|c|c|c|c|c|c|c|c|c|}
\hline \multirow{2}{*}{$\begin{array}{c}\text { Body } \\
\text { length }\end{array}$} & \multirow{2}{*}{$\begin{array}{l}\text { Dorsal } \\
\text { fin } \\
\text { spines }\end{array}$} & \multirow{2}{*}{$\begin{array}{c}\text { Dorsal } \\
\text { fin } \\
\text { rays }\end{array}$} & \multirow{2}{*}{$\begin{array}{c}\text { Anal } \\
\text { fin } \\
\text { rays }\end{array}$} & \multicolumn{2}{|c|}{$\begin{array}{l}\text { Pectoral } \\
\text { fin rays }\end{array}$} & \multirow{2}{*}{$\begin{array}{l}\text { Pelvic fin } \\
\text { spine } \\
\text { and rays }\end{array}$} & \multirow{2}{*}{$\begin{array}{c}\text { Preoper- } \\
\text { cular } \\
\text { spines }\end{array}$} & \multirow{2}{*}{$\begin{array}{c}\text { Ventral } \\
\text { midline } \\
\text { melano- } \\
\text { phores }\end{array}$} \\
\hline & & & & Left & Right & & & \\
\hline 11.7 & VII & 28 & 19 & 13 & 12 & - & - & $\mathrm{N}^{2}$ \\
\hline 16.6 & IX & 28 & 19 & 14 & $\mathrm{~N}$ & - & 4 & $\mathrm{~N}$ \\
\hline
\end{tabular}

${ }^{1}$ Not present as a distinct row.

${ }^{2} \mathrm{~N}=$ Not examined.

\section{Radulinus asprellus Gilbert}

(Figures 26, 27; Tables 35, 36)

Literature. Larvae of this species have not been previously described.

Distinguishing Features. The smallest larvae we have collected are $\sim 4.5 .5 \mathrm{~mm}$ long and probably recently hatched. The largest specimens captured pelagically, 14-15 $\mathrm{mm}$, have developed most juvenile characteristics including adult fin complements, increased pigmentation, and lateral line scales.

Larvae of $R$. asprellus are one of the most heavily pigmented among cottids. Melanophores occur over most

Table 34.-Measurements $(\mathrm{mm})$ of larvae of Nautichthys oculofasciatus. (Specimen above dashed line is undergoing notochord flexion.)

\begin{tabular}{|c|c|c|c|c|c|c|c|c|}
\hline $\begin{array}{l}\text { Body } \\
\text { length }\end{array}$ & $\begin{array}{l}\text { Head } \\
\text { length }\end{array}$ & $\begin{array}{l}\text { Snout } \\
\text { length }\end{array}$ & $\begin{array}{c}\text { Eye } \\
\text { diameter }\end{array}$ & $\begin{array}{l}\text { Snout to } \\
\text { anus length }\end{array}$ & $\begin{array}{l}\text { Body depth } \\
\text { at pectoral } \\
\text { fin base }\end{array}$ & $\begin{array}{l}\text { Pectoral } \\
\text { fin length }\end{array}$ & $\begin{array}{l}2 \mathrm{~d} \text { preoper- } \\
\text { cular } \\
\text { spine length }\end{array}$ & $\begin{array}{c}\text { Parietal } \\
\text { spine length }\end{array}$ \\
\hline 11.7 & 3.4 & 0.80 & 1.1 & 6.6 & 2.5 & 4.9 & - & - \\
\hline$\ldots$ & $\cdots$ & & & & $\cdots$ & $\cdots$ & $\ldots$ & $\ldots$ \\
\hline 16.6 & 4.5 & 1.1 & 1.3 & 8.4 & 3.8 & 9.8 & 0.20 & - \\
\hline
\end{tabular}

Table 35.-Meristics from young of Radulinus asprellus. (Specimens between dashed lines are undergoing notochord flexion.) $\left[{ }^{*}=\right.$ Specimens stained with Alizarin Red $\mathrm{S} ;{ }^{* *}=$ Dorsal fin spines and rays not distinguishable; ${ }^{* * *}=$ Present but not countable as distinct melanophores; $\mathrm{B}=$ Bases only; $\mathrm{D}=$ Damaged; $\mathrm{N}=$ Not examined.]

\begin{tabular}{|c|c|c|c|c|c|c|c|c|c|c|c|c|c|c|c|}
\hline \multirow{4}{*}{$\begin{array}{l}\text { Body } \\
\text { length }\end{array}$} & & & \multirow{4}{*}{$\begin{array}{c}\text { Anal } \\
\text { fin } \\
\text { rays }\end{array}$} & \multirow{3}{*}{\multicolumn{2}{|c|}{$\begin{array}{l}\text { Pectoral } \\
\text { fin rays }\end{array}$}} & \multirow{4}{*}{$\begin{array}{l}\text { Pelvic } \\
\text { fin } \\
\text { spine } \\
\text { \& rays }\end{array}$} & \multirow{4}{*}{$\begin{array}{c}\text { Preoper- } \\
\text { cular } \\
\text { spines }\end{array}$} & \multirow{4}{*}{$\begin{array}{l}\text { Ventral } \\
\text { midline** } \\
\text { melano- } \\
\text { phores }\end{array}$} & \multicolumn{4}{|c|}{ Caudal fin rays } & \multirow{2}{*}{\multicolumn{2}{|c|}{ Vertebrae }} & \multirow{4}{*}{$\begin{array}{c}\text { Branchi- } \\
\text { ostegal } \\
\text { rays }\end{array}$} \\
\hline & \multirow{2}{*}{\multicolumn{2}{|c|}{ Dorsal fin }} & & & & & & & \multicolumn{2}{|c|}{ Dorsal } & \multicolumn{2}{|c|}{ Ventral } & & & \\
\hline & & & & & & & & & Second- & Prin- & Prin- & Second- & Abdom- & Cau- & \\
\hline & Spines & Rays & & Left & Right & & & & & cipal & cipal & & & dal & \\
\hline 4.7 & - & - & - & - & - & - & - & $\mathrm{N}$ & $\mathrm{N}$ & $\mathrm{N}$ & $\mathrm{N}$ & $\mathrm{N}$ & $\mathrm{N}$ & $\mathrm{N}$ & $\mathrm{N}$ \\
\hline 5.2 & - & - & - & - & - & - & - & $\mathrm{N}$ & $\mathrm{N}$ & $\mathrm{N}$ & $\mathrm{N}$ & $\mathrm{N}$ & $\mathrm{N}$ & $\mathrm{N}$ & $\mathrm{N}$ \\
\hline $5.9^{*}$ & - & 一 & - & - & - & - & $\mathrm{N}$ & $\mathrm{N}$ & - & - & - & - & - & - & - \\
\hline 6.1 & - & - & - & - & - & - & - & $\mathrm{N}$ & $\mathrm{N}$ & $\mathrm{N}$ & $\mathrm{N}$ & $\mathrm{N}$ & $\mathrm{N}$ & $\mathrm{N}$ & $\mathrm{N}$ \\
\hline 6.7 & - & - & 一 & - & 一 & - & - & $\mathrm{N}$ & $\mathrm{N}$ & $\mathrm{N}$ & $\mathrm{N}$ & $\mathrm{N}$ & $\mathrm{N}$ & $\mathrm{N}$ & $\mathrm{N}$ \\
\hline 7.2 & - & - & - & - & - & - & 3 & $\mathrm{~N}$ & $\mathrm{~N}$ & $\mathrm{~N}$ & $\mathrm{~N}$ & $\mathrm{~N}$ & $\mathrm{~N}$ & $\mathrm{~N}$ & $\mathrm{~N}$ \\
\hline $7.8^{*}$ & - & - & - & - & - & - & $\mathrm{N}$ & $\mathrm{N}$ & - & - & - & - & - & - & - \\
\hline 7.9 & - & - & - & - & - & - & - & $\mathrm{N}$ & $\mathrm{N}$ & $\mathrm{N}$ & $\mathrm{N}$ & $\mathrm{N}$ & $\mathrm{N}$ & $\mathrm{N}$ & $\mathrm{N}$ \\
\hline $8.5^{*}$ & - & - & - & - & - & - & $\mathrm{N}$ & $\mathrm{N}$ & - & - & - & - & - & - & - \\
\hline 9.1 & $-22 \mathrm{~B}$ & -*** & $18 \mathrm{~B}$ & - & - & - & - & $\mathrm{N}$ & $\mathrm{N}$ & $\mathrm{N}$ & $\mathrm{N}$ & $\mathrm{N}$ & $\mathrm{N}$ & $\mathrm{N}$ & $\mathrm{N}$ \\
\hline 9.6 & VII & 21 & 22 & - & - & - & 3 & $\mathrm{~N}$ & $\mathrm{~N}$ & $\mathrm{~N}$ & $\mathrm{~N}$ & $\mathrm{~N}$ & $\mathrm{~N}$ & $\mathrm{~N}$ & $\mathrm{~N}$ \\
\hline 10.1 & -21 & $-* *$ & 22 & 18 & $\mathrm{~N}$ & - & - & $\mathrm{N}$ & $\mathrm{N}$ & $\mathrm{N}$ & $\mathrm{N}$ & $\mathrm{N}$ & $\mathrm{N}$ & $\mathrm{N}$ & $\mathrm{N}$ \\
\hline 10.9 & $\mathrm{X}$ & 22 & 22 & 19 & $\mathrm{~N}$ & Buds & 4 & $\mathrm{~N}$ & $\mathrm{~N}$ & $\mathrm{~N}$ & $\mathrm{~N}$ & $\mathrm{~N}$ & $\mathrm{~N}$ & $\mathrm{~N}$ & $\mathrm{~N}$ \\
\hline 11.4 & -23 & _** & 22 & 18 & 18 & Buds & 4 & $\mathrm{~N}$ & $\mathrm{~N}$ & $\mathrm{~N}$ & $\mathrm{~N}$ & $\mathrm{~N}$ & $\mathrm{~N}$ & $\mathrm{~N}$ & $\mathrm{~N}$ \\
\hline $11.4^{*}$ & $\mathrm{X}$ & 21 & 23 & - & - & - & $\mathrm{N}$ & $\mathrm{N}$ & - & 5 & 5 & 一 & - & - & - \\
\hline 11.5 & IX & 22 & 24 & 18 & 18 & Buds & 4 & $\mathrm{~N}$ & $\mathrm{~N}$ & $\mathrm{~N}$ & $\mathrm{~N}$ & $\mathrm{~N}$ & $\mathrm{~N}$ & $\mathrm{~N}$ & $\mathrm{~N}$ \\
\hline $11.7^{*}$ & $\mathrm{X}$ & 22 & 22 & 16 & $\mathrm{~N}$ & - & $\mathrm{N}$ & $\mathrm{N}$ & - & 5 & 5 & - & 12 & 20 & 6 \\
\hline 12.0 & IX & 22 & 23 & 17 & 17 & Buds & 4 & $\mathrm{~N}$ & $\mathrm{~N}$ & $\mathrm{~N}$ & $\mathrm{~N}$ & $\mathrm{~N}$ & $\mathrm{~N}$ & $\mathrm{~N}$ & $\mathrm{~N}$ \\
\hline $12.0^{*}$ & $\mathrm{X}$ & 21 & 24 & 18 & 19 & $\mathrm{I}, 3$ & $\mathrm{~N}$ & $\mathrm{~N}$ & - & 6 & 6 & - & 12 & 23 & 6 \\
\hline 12.6 & IX & 20 & 22 & 19 & 18 & I,3 & 4 & $\mathrm{~N}$ & $\mathrm{~N}$ & $\mathrm{~N}$ & $\mathrm{~N}$ & $\mathrm{~N}$ & $\mathrm{~N}$ & $\mathrm{~N}$ & $\mathrm{~N}$ \\
\hline 12.6 & $\mathrm{X}$ & 23 & 24 & 19 & 19 & $\mathrm{I}, 3$ & 4 & $\mathrm{~N}$ & $\mathrm{~N}$ & $\mathrm{~N}$ & $\mathrm{~N}$ & $\mathrm{~N}$ & $\mathrm{~N}$ & $\mathrm{~N}$ & $\mathrm{~N}$ \\
\hline 13.0 & IX & 22 & 24 & 18 & 19 & Buds & 4 & $\mathrm{~N}$ & $\mathrm{~N}$ & $\mathrm{~N}$ & $\mathrm{~N}$ & $\mathrm{~N}$ & $\mathrm{~N}$ & $\mathrm{~N}$ & $\mathrm{~N}$ \\
\hline $13.0^{*}$ & VIII & D & 23 & 18 & 18 & I,3 & $\mathrm{N}$ & $\mathrm{N}$ & - & 6 & 6 & - & 12 & 27 & 6 \\
\hline $13.9^{*}$ & $\mathrm{X}$ & 22 & 23 & 18 & 18 & $\mathrm{I}, 3$ & $\mathrm{~N}$ & $\mathrm{~N}$ & 3 & 6 & 6 & 2 & 12 & 27 & 6 \\
\hline 14.1 & IX & 23 & 23 & 18 & 18 & I,3 & 4 & $\mathrm{~N}$ & $\mathrm{~N}$ & $\mathrm{~N}$ & $\mathrm{~N}$ & $\mathrm{~N}$ & $\mathrm{~N}$ & $\mathrm{~N}$ & $\mathrm{~N}$ \\
\hline 14.1 & $\mathrm{X}$ & 22 & 23 & 19 & 19 & $\mathrm{I}, 3$ & 4 & $\mathrm{~N}$ & $\mathrm{~N}$ & $\mathrm{~N}$ & $\mathrm{~N}$ & $\mathrm{~N}$ & $\mathrm{~N}$ & $\mathrm{~N}$ & $\mathrm{~N}$ \\
\hline 14.4 & IX & 22 & 24 & 18 & 18 & I,3 & 4 & $\mathrm{~N}$ & $\mathrm{~N}$ & $\mathrm{~N}$ & $\mathrm{~N}$ & $N$ & $\mathrm{~N}$ & $\mathrm{~N}$ & $\mathrm{~N}$ \\
\hline 14.4 & $\mathrm{X}$ & 23 & 24 & 19 & 19 & I,3 & 4 & $\mathrm{~N}$ & $\mathrm{~N}$ & $\mathrm{~N}$ & $\mathrm{~N}$ & $\mathrm{~N}$ & $\mathrm{~N}$ & $\mathrm{~N}$ & $\mathrm{~N}$ \\
\hline $14.7^{*}$ & IX & 22 & 23 & 19 & 19 & $\mathrm{I}, 3$ & $\mathrm{~N}$ & $\mathrm{~N}$ & 3 & 6 & 6 & 2 & 12 & 27 & 6 \\
\hline $15.2^{*}$ & IX & 23 & 24 & 18 & 18 & I, 3 & $\mathrm{~N}$ & $\mathrm{~N}$ & 3 & 6 & 6 & 2 & 12 & 27 & 6 \\
\hline
\end{tabular}



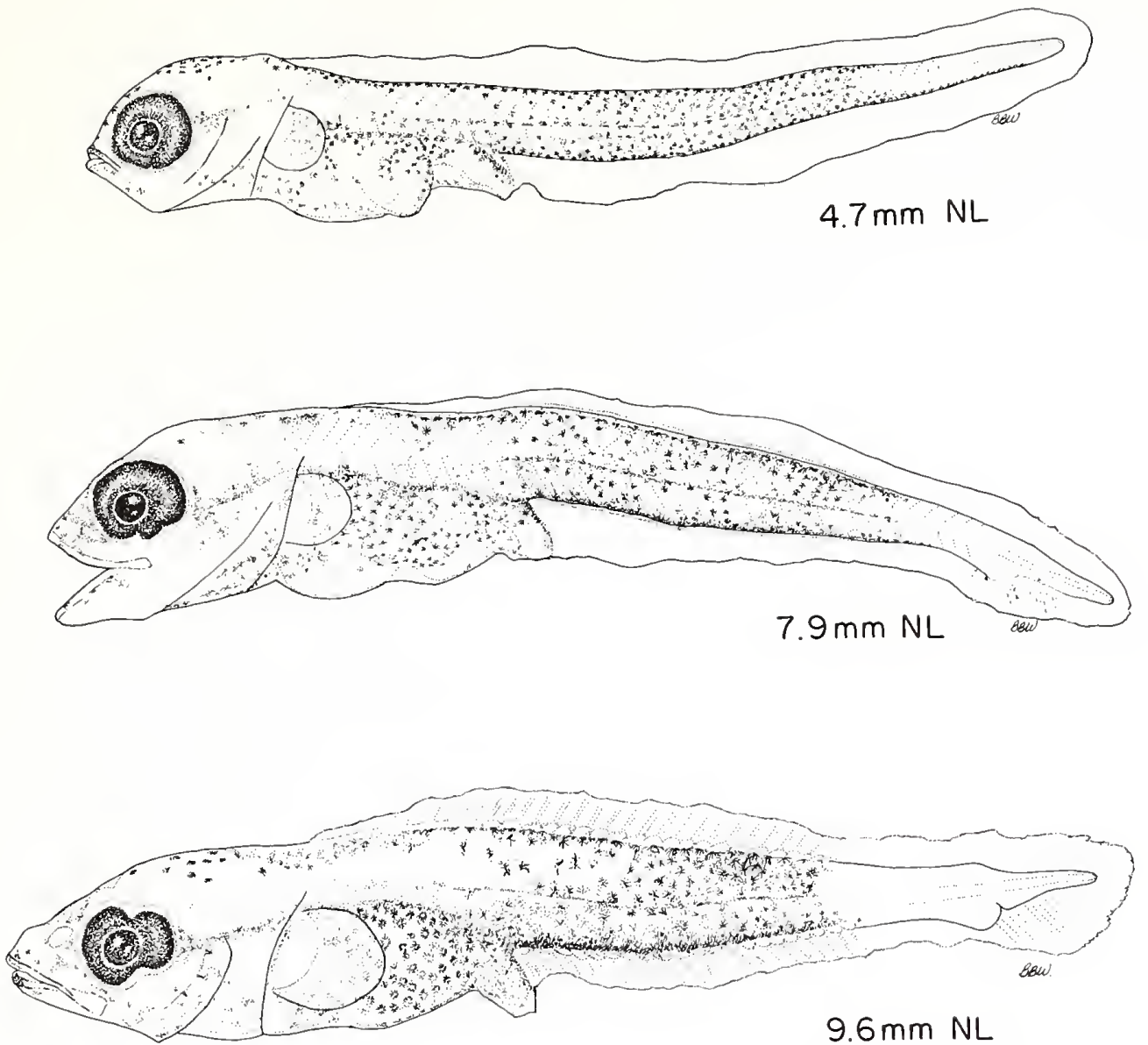

Figure 26.-Larvae of Radulinus asprellus.

of the body including the head, most of the gut, along dorsal and ventral midlines, and laterally except dorsolaterally above the body midline over the gut region and dorsally and laterally on the tail tip. This pigment is somewhat darker along the dorsal and ventral body midlines. Some ventral midline melanophores extend beyond the end of the lateral body pigment onto the tail tip, particularly in smaller specimens. A distinctive series of elongate melanophores occurs along the lateral midline appearing almost as a solid line. The presence of these melanophores help distinguish larvae of $R$. asprellus from Scorpaenichthys marmoratus which they resemble at small sizes. Pigmentation generally increases with development with only the tail tip or caudal peduncle remaining unpigmented. The lateral midline pigment is noticeable on all but the largest specimens.

Four small spines develop along the preopercular margin, visible by $\sim 10-11 \mathrm{~mm}$. They never become prominent. A parietal and nuchal spine develop as 2 minute spines which soon appear only as bumps. A nasal spine is evident on the largest transforming specimens $\sim 14-15 \mathrm{~mm}$.

The gut is rather distinctively coiled with snout to anus length ranging from $\sim 44$ to $54 \% \mathrm{SL}$. The snout becomes quite pointed further helping to distinguish these larvae from $S$. marmoratus. The larvae are relatively slender with body depth at the pectoral fin base never exceeding $25 \%$ SL during the pelagic phase and always $<20 \% \mathrm{SL}$ in specimens $<10 \mathrm{~mm}$. The adult complement of all fin rays or ray elements is attained by $\sim 11$ $12 \mathrm{~mm}$.

Discussion. Three species of Radulinus occur in the northeast Pacific. Larvae of $R$. boleoides are described in 

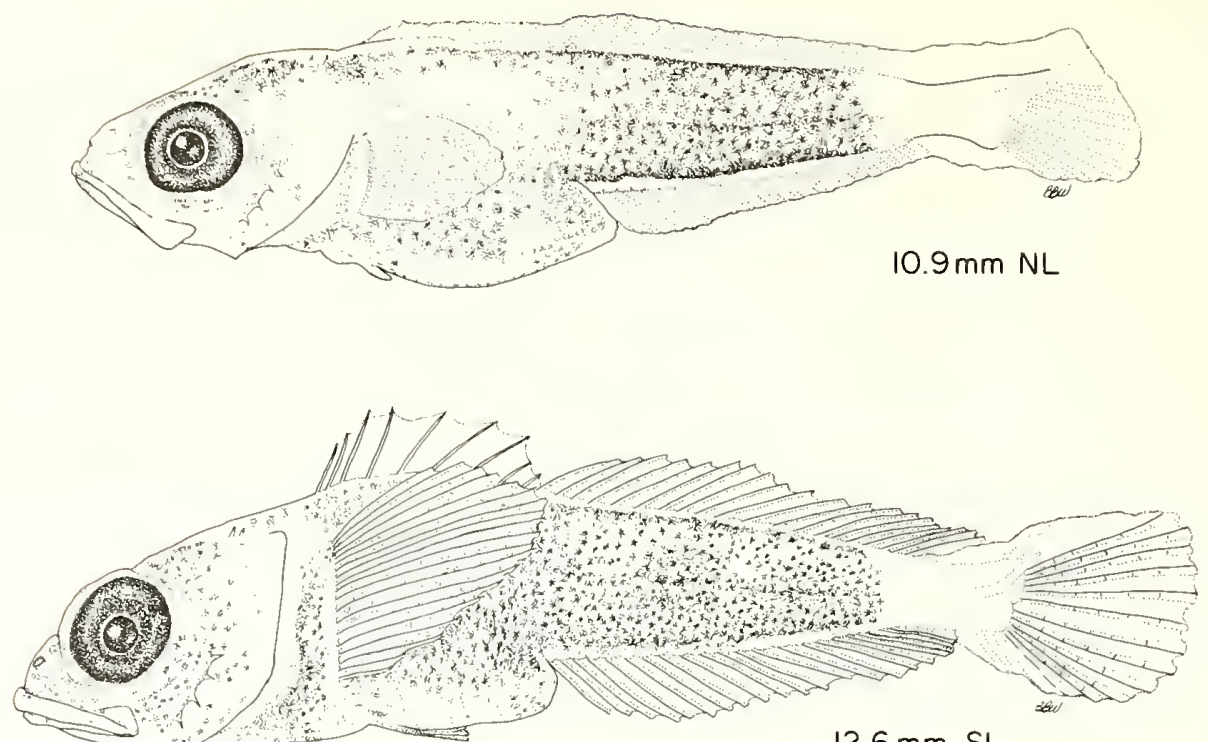

$12.6 \mathrm{~mm} \mathrm{SL}$

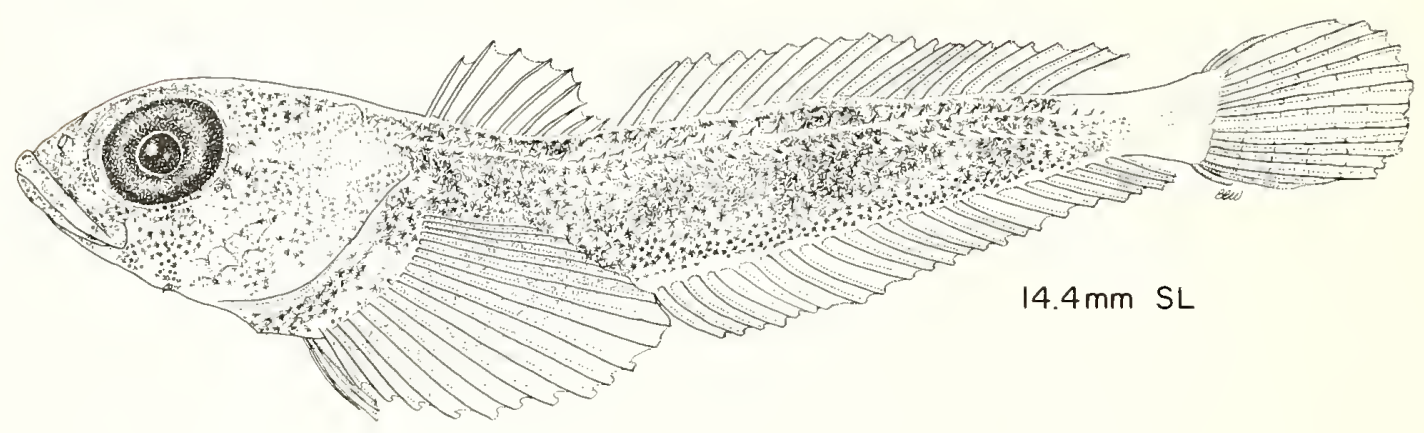

Figure 27.-Young of Radulinus asprellus.

the next section. They are distinguishable from $R$. asprellus on the basis of body proportions and small pigment differences as given in that section, at least for the size range described. Larvae of the third species, $R$. vinculus, are unknown.

Larvae of $R$. asprellus are one of the more heavily pigmented cottids along with, e.g., Scorpaenichyths marmoratus, Rhamphocottus richardsoni, and Blepsias cirrhosus (Blackburn 1973; Marliave 1975), all of which have melanophores covering most of the body except the tail tip or caudal peduncle. Interestingly only one of these, $S$. marmoratus, is known to be common in the neuston, indicating larval pigmentation may not reflect habitat preference, at least in these species.

\section{Radulinus boleoides Gilbert}

(Figure 28; Tables 37, 38)

Literature. The larvae of this species have not been previously described.

Distinguishing Features. We have identified only two larvae as $R$. boleoides in our collections, 7.5 and $8.7 \mathrm{~mm}$ long. At comparative sizes they are somewhat more advanced in development than larvae of $R$. asprellus.

The pigment pattern closely resembles that of $R$. asprellus with melanophores covering most of the body laterally except the tail tip. A few ventral midline mela- 
Table 36.-Measurements (mm) of young of Radulinus asprellus. (Specimens between dashed lines are undergoing notochord flexion.)

\begin{tabular}{|c|c|c|c|c|c|c|c|c|}
\hline $\begin{array}{l}\text { Body } \\
\text { length }\end{array}$ & $\begin{array}{r}\text { Head } \\
\text { length }\end{array}$ & $\begin{array}{l}\text { Snout } \\
\text { length }\end{array}$ & $\begin{array}{c}\text { Eye } \\
\text { diameter }\end{array}$ & $\begin{array}{c}\text { Snout to } \\
\text { anus length }\end{array}$ & $\begin{array}{c}\text { Body depth } \\
\text { at pectoral } \\
\text { fin base } \\
\end{array}$ & $\begin{array}{r}\text { Pectoral } \\
\text { fin length }\end{array}$ & $\begin{array}{l}\text { 2d preoper- } \\
\text { cular } \\
\text { spine length }\end{array}$ & $\begin{array}{c}\text { Parietal } \\
\text { spine length }\end{array}$ \\
\hline 4.7 & 1.1 & 0.10 & 0.51 & 2.6 & 0.86 & 0.47 & - & - \\
\hline 5.2 & 1.2 & 0.20 & 0.47 & 2.4 & 0.82 & 0.27 & - & - \\
\hline 6.1 & 1.3 & 0.32 & 0.54 & 2.8 & 0.98 & 0.27 & - & - \\
\hline 6.7 & 1.6 & 0.35 & 0.62 & 3.3 & 1.1 & 0.35 & - & - \\
\hline 7.2 & 1.9 & 0.43 & 0.58 & 3.4 & 1.2 & 0.35 & - & - \\
\hline 7.9 & 1.8 & 0.39 & 0.70 & 3.5 & 1.3 & 0.55 & - & - \\
\hline 9.1 & 2.3 & 0.56 & 0.56 & 4.2 & 1.6 & 0.55 & - & - \\
\hline 9.6 & 2.7 & 0.82 & 0.82 & 4.6 & 1.8 & 0.78 & - & - \\
\hline 10.1 & 2.4 & $\sim 0.50$ & 0.88 & 4.9 & 1.8 & 0.80 & - & - \\
\hline 10.9 & 2.9 & 0.78 & 1.0 & 5.9 & 2.6 & 1.1 & - & - \\
\hline 11.4 & 3.0 & 0.72 & 1.0 & 6.0 & 2.6 & 1.8 & - & - \\
\hline 11.5 & 3.5 & 0.88 & 1.0 & 6.2 & 2.5 & 2.0 & 0.27 & - \\
\hline 12.0 & 3.6 & 1.0 & 1.2 & 6.3 & 2.5 & 2.1 & 0.23 & - \\
\hline 12.6 & 4.1 & 0.88 & 1.4 & 6.6 & 3.0 & 3.1 & 0.35 & - \\
\hline 12.6 & 3.7 & 0.88 & 1.21 & 6.6 & 3.0 & 1.8 & 0.23 & - \\
\hline 13.0 & 3.6 & 0.96 & 1.1 & 6.2 & 2.6 & 1.7 & 0.27 & - \\
\hline 14.1 & 4.5 & 0.96 & 1.4 & 7.6 & 3.5 & 2.0 & 0.40 & - \\
\hline 14.1 & 4.8 & 1.3 & 1.4 & 7.0 & 2.8 & 2.7 & 0.46 & - \\
\hline 14.4 & 4.7 & 1.1 & 1.5 & 7.0 & 3.0 & 3.7 & 0.43 & - \\
\hline 14.4 & 4.2 & 1.0 & 1.4 & 7.0 & 3.4 & 2.2 & 0.35 & - \\
\hline
\end{tabular}

\section{Radulinus boleoides}

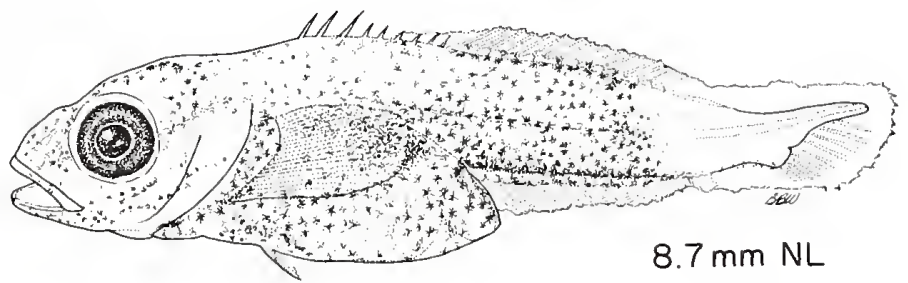

Figure 28.-Larva of Radulinus boleoides.

Table 37.-Meristics from larvae of Radulinus boleoides. (Specimens are undergoing notochord flexion.)

\begin{tabular}{|c|c|c|c|c|c|c|c|c|}
\hline $\begin{array}{l}\text { Body } \\
\text { length }\end{array}$ & $\begin{array}{l}\text { Dorsal } \\
\text { fin } \\
\text { spines }\end{array}$ & $\begin{array}{l}\text { Dorsal } \\
\text { fin } \\
\text { rays }\end{array}$ & $\begin{array}{c}\text { Anal } \\
\text { fin } \\
\text { rays }\end{array}$ & $\begin{array}{r}\text { Pec } \\
\text { fin } \\
\text { Left }\end{array}$ & $\begin{array}{l}\text { toral } \\
\text { rays } \\
\text { Right }\end{array}$ & $\begin{array}{l}\text { Pelvic fin } \\
\text { spine } \\
\text { and rays }\end{array}$ & $\begin{array}{l}\text { Preoper- } \\
\text { cular } \\
\text { spines }\end{array}$ & $\begin{array}{l}\text { Ventral } \\
\text { midline } \\
\text { melano- } \\
\text { phores }^{1}\end{array}$ \\
\hline 7.5 & VIII & 20 & 15 & 18 & $\mathrm{~N}^{2}$ & Buds & - & $\mathrm{N}$ \\
\hline 8.7 & IX & 16 & 20 & 19 & $N$ & I,3 & - & $\mathrm{N}$ \\
\hline
\end{tabular}

${ }^{2}$ Present but not countable as distinct melanophores.

${ }^{2} \mathrm{~N}=$ Not examined. nophores extend onto the tail tip. They differ somewhat in the posterior extent of the lateral pigment which is less in $R$. boleoides than in $R$. asprellus of similar size, i.e., a greater portion of the tail tip is pigmentless in $R$. boleoides. Larvae of $R$. boleoides also have a distinctive series of melanophores along the lateral midline as do $R$. asprellus.

No head spines are visible on the two flexion larvae in our collection, although they may develop later.

Table 38.-Measurements ( $\mathrm{mm}$ ) of larvae of Radulinus boleoides. (Specimens are undergoing notochord flexion.)

\begin{tabular}{ccccccccc}
\hline $\begin{array}{c}\text { Body } \\
\text { length }\end{array}$ & $\begin{array}{r}\text { Head } \\
\text { length }\end{array}$ & $\begin{array}{c}\text { Snout } \\
\text { length }\end{array}$ & $\begin{array}{c}\text { Eye } \\
\text { diameter }\end{array}$ & $\begin{array}{c}\text { Snout to } \\
\text { anus length }\end{array}$ & $\begin{array}{c}\text { Body depth } \\
\text { at pectoral } \\
\text { fin base }\end{array}$ & $\begin{array}{c}\text { Pectoral } \\
\text { fin length }\end{array}$ & $\begin{array}{c}\text { 2d preoper- } \\
\text { cular } \\
\text { spine length }\end{array}$ & $\begin{array}{c}\text { Parietal } \\
\text { spine length }\end{array}$ \\
\hline 7.5 & 2.4 & 0.58 & 0.70 & 4.4 & 1.7 & 0.98 & - & - \\
8.7 & 2.6 & 0.64 & 0.78 & 5.0 & 2.0 & 1.2 & - & - \\
\hline
\end{tabular}


The coiled gut is rather prominent and distinctive, as in $R$. asprellus, but snout to anus length is considerably greater in $R$. boleoides ( $58 \% \mathrm{SL}$ ) than $R$. asprellus (44$47 \% \mathrm{SL}$ ) of similar size. Body depth at the pectoral fin base is also greater in $R$. boleoides (22-23\% SL) than $R$. asprellus (16-18\% SL). The pectoral fin is relatively longer in $R$. boleoides (13-14\% SL) compared to $R$. asprellus at that size (5-7\% SL). Both specimens of $R$. boleoides are undergoing notochord flexion and adult fin ray complements have not been attained, explaining the discrepancies in the fin ray counts in Table 37.

Discussion. Identification was based on the strong similarity of these larvae to $R$. asprellus and the major differences in body proportions which were obviously not caused by distortion. The only other species of Radulinus which occurs off Oregon is $R$. boleoides and it is relatively rare, explaining the paucity of larvae in our collections. Our two specimens were taken 9 and $18 \mathrm{~km}$ off the Oregon coast in March and April.

\section{Rhamphocottus richardsoni Günther}

(Figure 29; Tables 39, 40)

Literature. Larvae $(6.7,10 \mathrm{~mm} \mathrm{SL})$ were illustrated and briefly described by Blackburn (1973) and young $(10,11.5,15 \mathrm{~mm}$ TL) by Marliave (1975).

Distinguishing Features. Hatching occurs $\sim 6-7 \mathrm{~mm}$ and transformation at $\sim 14-15 \mathrm{~mm}$ (Blackburn 1973; Marliave 1975). Pelagic specimens in our collections range from 6.0 to $11.8 \mathrm{~mm}$.

Larvae are rather heavily pigmented with melanophores covering most of the body except the tail tip or caudal peduncle. Pigment covers the cheeks and ventral surface of the gut on the smallest specimens. Pigment does not appear noticeably darker along the dorsal and ventral body margins and no distinct line of melanophores occurs along the lateral midline. Some melanophores occur on the ventral finfold and occasionally on the dorsal finfold. The preanal finfold is darkly pigmented. Melanophores are present on the base of the pectoral fin. The caudal peduncle remains unpigmented through the pelagic period. Body pigment changes little with development except as transformation approaches, pigment is added to the spinous dorsal fin and pectoral fin base, and pigment bands begin to show on the body.

Only 1 spine develops on the dorsal margin of preopercle, evident by $\sim 10 \mathrm{~mm}$. Smaller spiny projections appear along the preopercular margin which are modified scales developing over the head region. A postocular spine is apparent over the eye by $\sim 8 \mathrm{~mm}$ and becomes rather pronounced in larger specimens. A parietal and a nuchal spine develop and fuse together appearing as one. Two spines become obvious in the posttemporal-supracleithral region and a cleithral spine and nasal spine are evident on our largest specimens.

Body shape is characteristic. Larvae are deep bodied, increasing from 29 to $40 \%$ SL between 8 and $12 \mathrm{~mm}$. Snout to anus distance is $>60 \%$ SL. By $10 \mathrm{~mm}$, larvae begin to resemble adults in form. The larvae have a distinct pigmented preanal finfold which remains evident anterior to the anal opening at least until $\sim 12 \mathrm{~mm}$. To our knowledge, a preanal finfold has been reported in Scorpaenichthys marmoratus (O'Connell 1953), Hemitripterus americanus (Warfel and Merriman 1944; Fuiman 1976), possibly $H$. villosus as indicated on a figure by Okiyama and Sando (1976), Myoxocephalus quadricornis, M. scorpius (Khan 1972), possibly M. aenaeus based on figures by Lund and Marcy (1975), possibly Gymnocanthus iricuspis and G. herzensteini based on illustrations by Rass (1949) and Kyushin (1970), Eno-

Table 39.-Meristics from larvae of Rhamphocottus richardsoni. (Specimen above dashed line is undergoing notochord flexion.)

$\left[^{*}=\right.$ Specimen stained with Alizarin Red $\mathrm{S} ;{ }^{* *}=$ Dorsal fin spines and rays not distinguishable; ${ }^{* * *}=$ Present but not countable as distinct melanophores; $\mathrm{B}=$ Bases only; $\mathrm{N}$ = Not examined.]

\begin{tabular}{|c|c|c|c|c|c|c|c|c|c|c|c|c|c|c|c|}
\hline \multirow{4}{*}{$\begin{array}{l}\text { Body } \\
\text { length }\end{array}$} & & & \multirow{4}{*}{$\begin{array}{c}\text { Anal } \\
\text { fin } \\
\text { rays }\end{array}$} & \multirow{3}{*}{\multicolumn{2}{|c|}{$\begin{array}{l}\text { Pectoral } \\
\text { fin rays }\end{array}$}} & \multirow{4}{*}{$\begin{array}{l}\text { Pelvic } \\
\text { fin } \\
\text { spine } \\
\text { \& rays }\end{array}$} & \multirow{4}{*}{$\begin{array}{l}\text { Preoper- } \\
\text { cular } \\
\text { spines }\end{array}$} & \multirow{4}{*}{$\begin{array}{l}\text { Ventral } \\
\text { midline * } \\
\text { melano- } \\
\text { phores }\end{array}$} & \multicolumn{4}{|c|}{ Caudal fin rays } & \multirow{2}{*}{\multicolumn{2}{|c|}{ Vertebrae }} & \multirow{4}{*}{$\begin{array}{c}\text { Branchi- } \\
\text { ostegal } \\
\text { rays }\end{array}$} \\
\hline & \multirow{2}{*}{\multicolumn{2}{|c|}{ Dorsal fin }} & & & & & & & $\begin{array}{ll}* * & \text { Dor } \\
\end{array}$ & & & entral & & & \\
\hline & & & & & & & & & Second- & Prin- & Prin- & Second- & Abdom- & Cau- & \\
\hline & Spines & Rays & & Left & Right & & & & & cipal & cipal & ary & & & \\
\hline 8.4 & $-14 \mathrm{~B}$ & & $6 \mathrm{~B}$ & - & - & Buds & - & $\mathrm{N}$ & $\mathrm{N}$ & $\mathrm{N}$ & $\mathrm{N}$ & $\mathrm{N}$ & $\mathrm{N}$ & $\mathrm{N}$ & $\mathrm{N}$ \\
\hline 10.6 & VII & 13 & 6 & 16 & 16 & $\mathrm{I}, 3$ & 1 & $\mathrm{~N}$ & $\mathrm{~N}$ & $\mathrm{~N}$ & $\mathrm{~N}$ & $\mathrm{~N}$ & $\mathrm{~N}$ & $\mathrm{~N}$ & $\mathrm{~N}$ \\
\hline 11.7 & VIII & 12 & 6 & 15 & 16 & $\mathrm{I}, 3$ & 1 & $\mathrm{~N}$ & $\mathrm{~N}$ & $\mathrm{~N}$ & $\mathrm{~N}$ & $\mathrm{~N}$ & $\mathrm{~N}$ & $\mathrm{~N}$ & $\mathrm{~N}$ \\
\hline $11.8^{*}$ & VIII & 13 & 7 & 16 & 16 & $\mathrm{I}, 3$ & 1 & $\mathrm{~N}$ & 1 & 6 & 5 & 1 & 12 & 15 & 6 \\
\hline
\end{tabular}

Table 40.-Measurements $(\mathrm{mm})$ of larvae of Rhamphocottus richardsoni. (Specimen above dashed line is undergoing notochord flexion.)

\begin{tabular}{cccccccc}
\hline $\begin{array}{c}\text { Body } \\
\text { length }\end{array}$ & $\begin{array}{c}\text { Head } \\
\text { length }\end{array}$ & $\begin{array}{c}\text { Snout } \\
\text { length }\end{array}$ & $\begin{array}{c}\text { Eye } \\
\text { diameter }\end{array}$ & $\begin{array}{c}\text { Snout to } \\
\text { anus length }\end{array}$ & $\begin{array}{c}\text { Body depth } \\
\text { at pectoral } \\
\text { fin base }\end{array}$ & $\begin{array}{c}\text { Pectoral } \\
\text { fin length }\end{array}$ & $\begin{array}{c}\text { preoper- } \\
\text { cular } \\
\text { spine length }\end{array} \begin{array}{c}\text { Parietal } \\
\text { spine length }\end{array}$ \\
\hline 8.4 & 2.6 & 0.55 & 0.94 & 5.5 & 2.4 & 1.0 & - \\
10.6 & 4.1 & 1.0 & 1.1 & 7.7 & 4.0 & 2.2 & 0.43 \\
11.7 & 4.8 & 1.0 & 1.3 & 8.1 & 4.7 & 2.6 & - \\
\hline
\end{tabular}



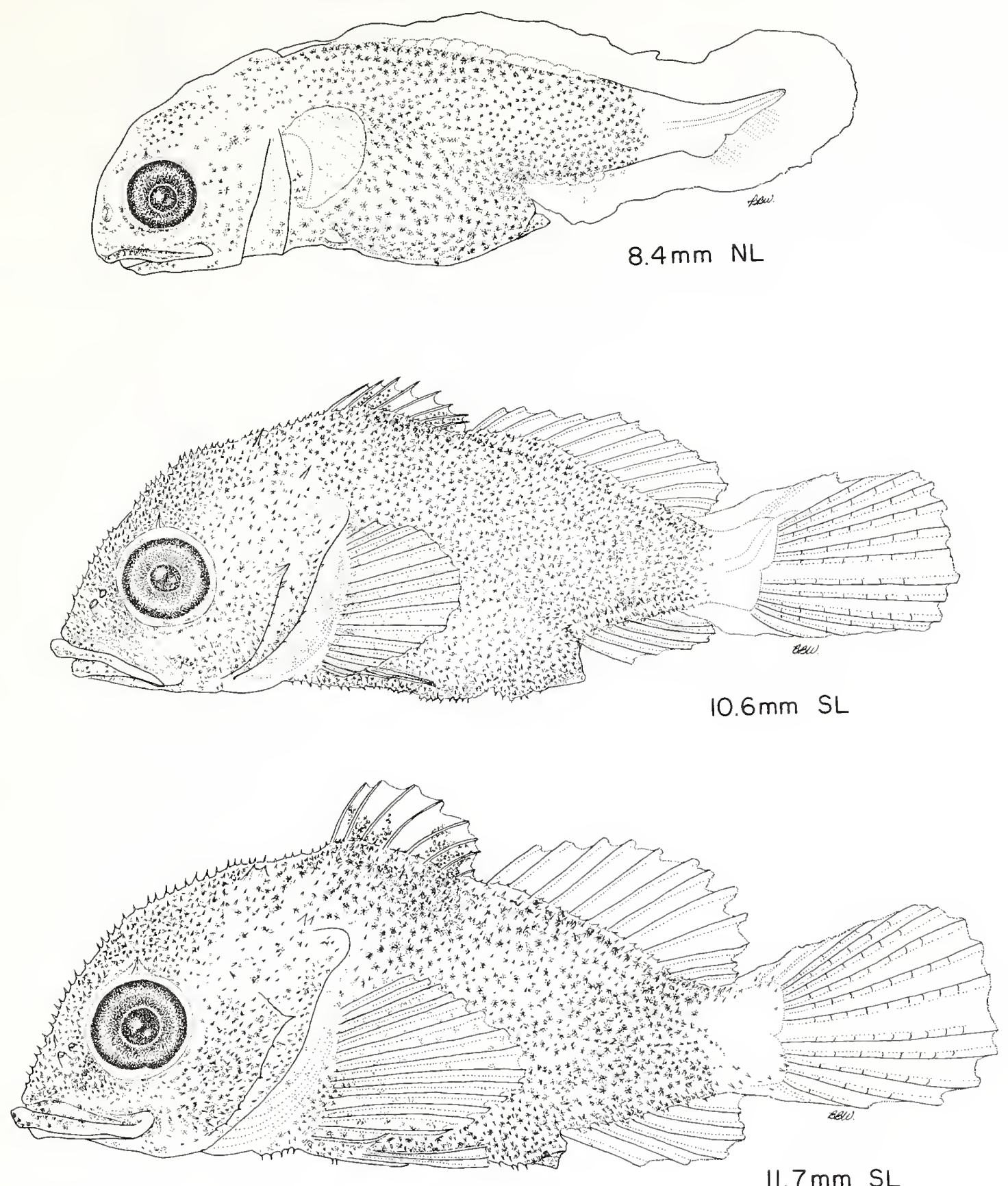

Figure 29.-Young of Rhamphocottus richardsoni. 
phrys bison (Misitano 1978), and E. bubalis and possibly E. lilljeborgi (Russell 1976), within the Cottidae.

Discussion. Rhamphocottus is a monotypic genus. The larvae are distinctive. They share the character of having a rather heavily pigmented body, except for the tail tip, with a number of other northeast Pacific species, as discussed under Radulinus asprellus, but their characteristic body shape renders them outstanding except perhaps at the smallest sizes. The heavily pigmented preanal finfold, and presence of pigment on the anal finfold, base of the pectoral fin, and the ventral surface of the gut help distinguish small larvae. The body becomes covered with distinctive spinelike scales while still in the pelagic habitat. The larvae are relatively rare in our collections with only seven identified specimens, all taken 2-9 $\mathrm{km}$ off the Oregon coast in March and April.

\section{Scorpaenichthys marmoratus (Ayres)}

(Figures 30, 31; Tables 41, 42)

Literature. Eggs and young $(5.85,6.26,10,17,30,48$ $\mathrm{mm}$ ) of this species were described by O'Connell (1953).

Distinguishing Features. Larvae are between 4 and 6 $\mathrm{mm}$ long at hatching. Most of our pelagic specimens are $<15 \mathrm{~mm}$. By $\sim 13-14 \mathrm{~mm}$ they have a juvenile appearance and fully formed fins. However, we have captured a $21.6 \mathrm{~mm}$ specimen pelagically and a $35 \mathrm{~mm}$ specimen in a neuston tow $9 \mathrm{~km}$ off Newport, Oreg. O'Connell (1953) reported specimens as large as $29 \mathrm{~mm}$ were collected with dip nets.

Larvae are very heavily pigmented over most of the body, usually appearing darker than larvae of Radulinus

\section{Scorpaenichthys marmoratus}
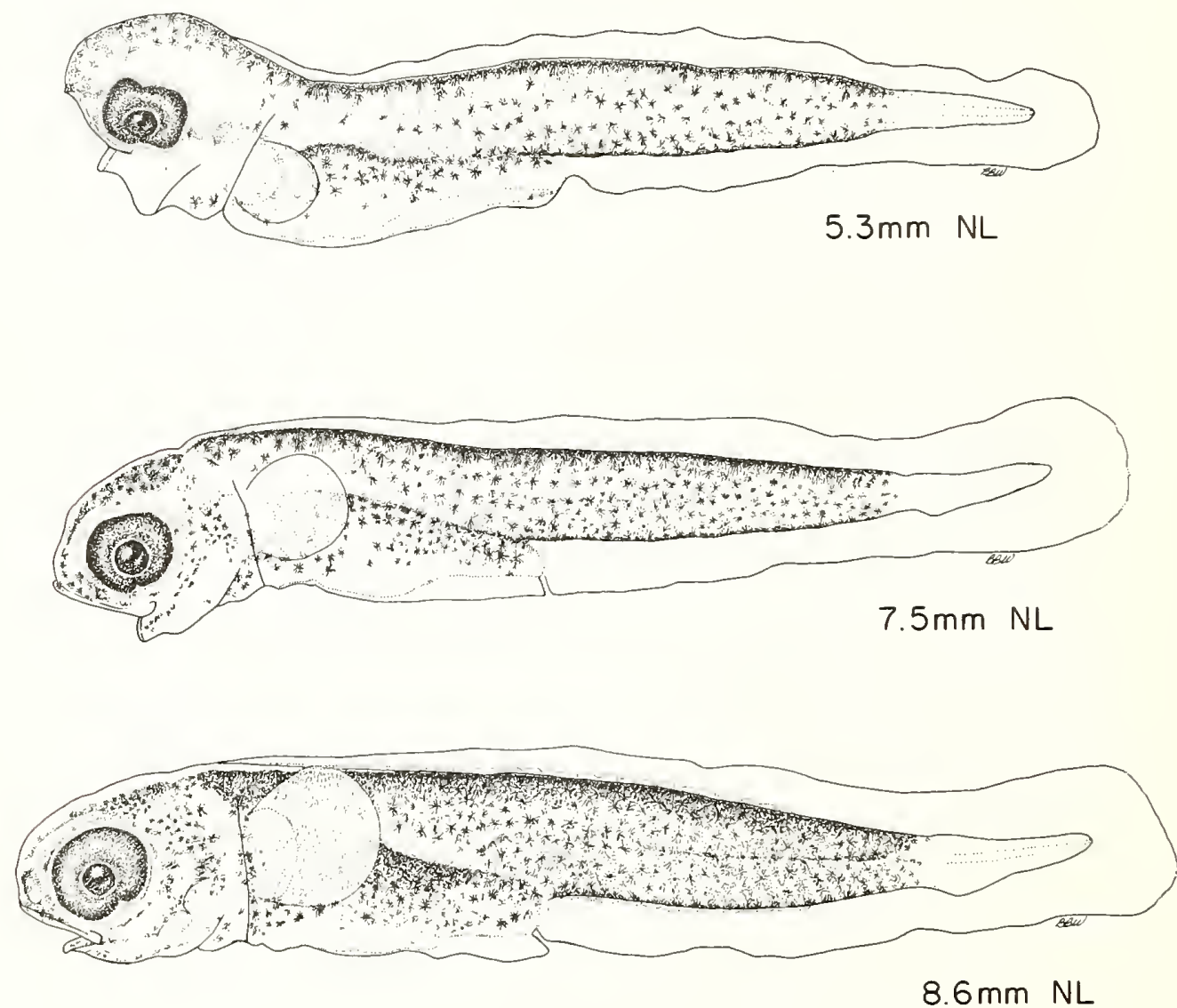

Figure 30.-Larvae of Scorpaenichthys marmoratus. 


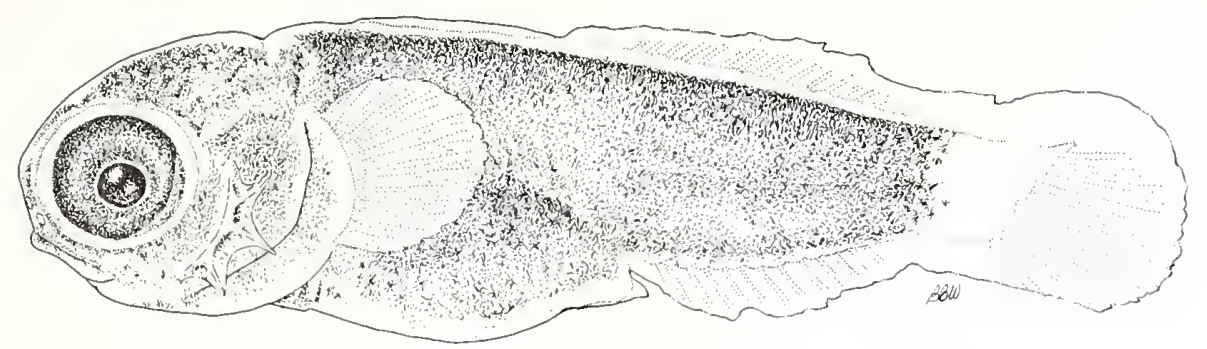

$8.7 \mathrm{~mm} \mathrm{SL}$

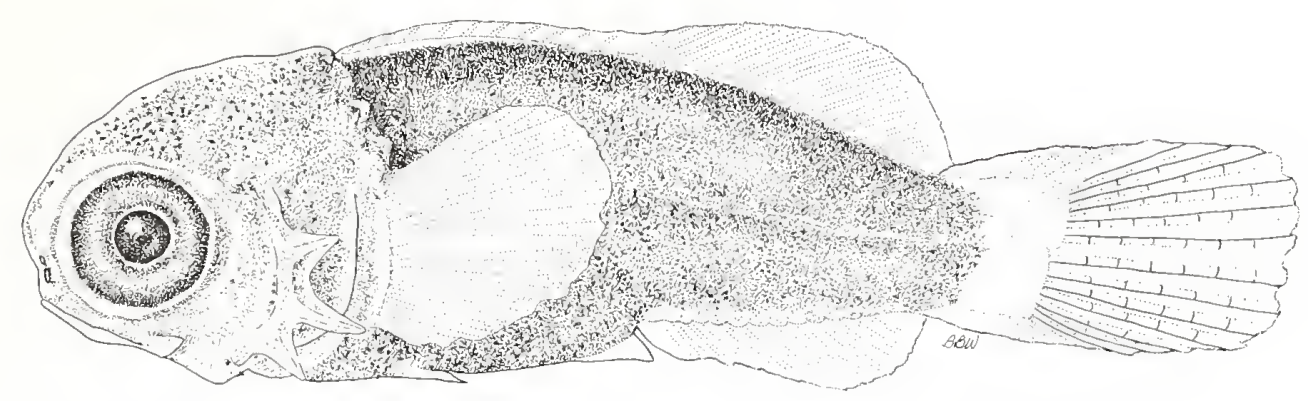

$10.4 \mathrm{~mm} \mathrm{SL}$

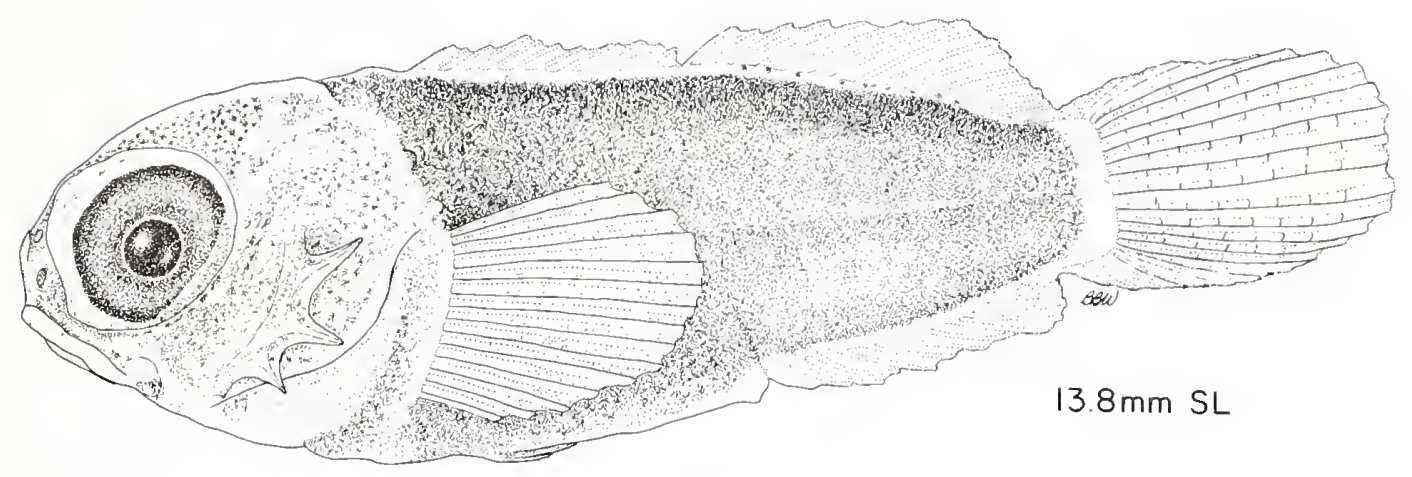

Figure 31.-Young of Scorpaenichthys marmoratus.

asprellus or Rhamphocottus richardsoni. In small larvae melanophores cover the head, the gut except the ventral margin, the dorsal body margin, the ventral margin of the tail, and the lateral body surface except for the tail tip. The lateral pigment extends more posteriorly than in Radulinus spp. The dorsal body margin, dorsal surface of the gut, and postanal ventral body margin appear darker than the rest of the body. The pectoral fin, preanal finfold, and body finfold are unpigmented. With development, melanophores are added on the head and laterally except along the ventral margin of the gut which remains unpigmented until $\sim 8-9 \mathrm{~mm}$ and the caudal peduncle which retains an unpigmented band at least until 14-15 $\mathrm{mm}$. As the median fins develop the dorsal and ventral body margins do not appear as heavily outlined. On specimens $\sim 13-14 \mathrm{~mm}$ a discrete melanophore can be seen at the base of most dorsal fin soft rays. Larvae generally do not develop a distinct line of pigment along the lateral midline as observed in larvae of Radulinus spp.

The margin of the preopercle develops 4 spines, not 3 as reported by O'Connell (1953), but only the upper 3 spines become pronounced. They are first noticeable $\sim 8$ 
$\mathrm{mm}$, and become striking in postflexion stages with the length of the $2 \mathrm{~d}$ spine ranging from 22 to $26 \%$ HL. Raised bumps develop in the parietal region, the posttemporalsupracleithral region, and the cleithral region, but spines never form. A nasal spine becomes obvious by $\sim 13-14$ $\mathrm{mm}$.

Preflexion larvae are relatively slender with body depth at pectoral fin base ranging from 17 to $19 \%$ SL.

Table 41.-Meristics from young of Scorpaenichthys marmoratus. (Specimens between dashed lines are undergoing notochord flexion.)

$\left[{ }^{*}=\right.$ Specimens stained with Alizarin Red $\mathbf{S} ;{ }^{* *}=$ Dorsal fin spines and rays not distinguishable; ${ }^{* * *}=$ Present but not countable as distinct melanophores; $\mathrm{B}=$ bases only; $\mathrm{N}=$ Not examined.]

\begin{tabular}{|c|c|c|c|c|c|c|c|c|c|c|c|c|c|c|c|}
\hline \multirow{4}{*}{$\begin{array}{l}\text { Body } \\
\text { length }\end{array}$} & & & \multirow{4}{*}{$\begin{array}{l}\text { Anal } \\
\text { fin } \\
\text { rays }\end{array}$} & \multirow{3}{*}{\multicolumn{2}{|c|}{$\begin{array}{l}\text { Pectoral } \\
\text { fin rays }\end{array}$}} & \multirow{4}{*}{$\begin{array}{l}\text { Pelvic } \\
\text { fin } \\
\text { spine } \\
\& \text { rays }\end{array}$} & \multirow{4}{*}{$\begin{array}{c}\text { Preoper- } \\
\text { cular } \\
\text { spines }\end{array}$} & \multirow{4}{*}{$\begin{array}{l}\text { Ventral } \\
\text { midline *, } \\
\text { melano- } \\
\text { phores }\end{array}$} & \multicolumn{4}{|c|}{ Caudal fin rays } & \multirow{2}{*}{\multicolumn{2}{|c|}{ Vertebrae }} & \multirow{4}{*}{$\begin{array}{c}\text { Branchi- } \\
\text { ostegal } \\
\text { rays }\end{array}$} \\
\hline & \multirow{2}{*}{\multicolumn{2}{|c|}{ Dorsal fin }} & & & & & & & ** Dors & & & entral & & & \\
\hline & & & & & & & & & Second- & Prin- & Prin- & Second- & Abdom- & Cau- & \\
\hline & Spines & Rays & & Left & Right & & & & ary & cipal & cipal & ary & inal & dal & \\
\hline $5.1^{*}$ & - & - & - & - & - & - & $\mathrm{N}$ & $\mathrm{N}$ & - & - & - & - & - & - & - \\
\hline 5.3 & - & - & - & - & - & - & - & $\mathrm{N}$ & $\mathrm{N}$ & $\mathrm{N}$ & $\mathrm{N}$ & $\mathrm{N}$ & $\mathrm{N}$ & $\mathrm{N}$ & $\mathrm{N}$ \\
\hline 5.4 & - & - & - & - & - & - & - & $\mathrm{N}$ & $\mathrm{N}$ & $\mathrm{N}$ & $\mathrm{N}$ & $\mathrm{N}$ & $\mathrm{N}$ & $\mathrm{N}$ & $\mathrm{N}$ \\
\hline 5.8 & - & - & - & - & - & - & - & $\mathrm{N}$ & $\mathrm{N}$ & $\mathrm{N}$ & $\mathrm{N}$ & $\mathrm{N}$ & $\mathrm{N}$ & $\mathrm{N}$ & $\mathrm{N}$ \\
\hline 6.1 & - & - & - & - & - & - & - & $\mathrm{N}$ & $\mathrm{N}$ & $\mathrm{N}$ & $\mathrm{N}$ & $\mathrm{N}$ & $\mathrm{N}$ & $\mathrm{N}$ & $\mathrm{N}$ \\
\hline 6.3 & - & - & - & - & - & - & - & $\mathrm{N}$ & $\mathrm{N}$ & $\mathrm{N}$ & $\mathrm{N}$ & $\mathrm{N}$ & $\mathrm{N}$ & $\mathrm{N}$ & $\mathrm{N}$ \\
\hline $6.6^{*}$ & - & - & - & - & - & - & $\mathrm{N}$ & $\mathrm{N}$ & - & - & - & - & - & - & - \\
\hline 7.5 & - & - & - & - . & - & - & - & $\mathrm{N}$ & $\mathrm{N}$ & $\mathrm{N}$ & $\mathrm{N}$ & $\mathrm{N}$ & $\mathrm{N}$ & $\mathrm{N}$ & $\mathrm{N}$ \\
\hline $7.5^{*}$ & - & - & - & - & - & - & $\mathrm{N}$ & $\mathrm{N}$ & - & - & - & - & - & - & - \\
\hline $7.7^{*}$ & - & - & - & - & - & - & $\mathrm{N}$ & $\mathrm{N}$ & - & - & - & - & - & - & - \\
\hline 8.1 & - & - & - & - & - & - & 2 & $\mathrm{~N}$ & $\mathrm{~N}$ & $\mathrm{~N}$ & $\mathrm{~N}$ & $\mathrm{~N}$ & $\mathrm{~N}$ & $\mathrm{~N}$ & $\mathrm{~N}$ \\
\hline 8.1 & -1 & B-** & $12 \mathrm{~B}$ & - & - & - & 4 & $\mathrm{~N}$ & $\mathrm{~N}$ & $\mathrm{~N}$ & $\mathrm{~N}$ & $\mathrm{~N}$ & $\mathrm{~N}$ & $\mathrm{~N}$ & $\mathrm{~N}$ \\
\hline $8.2^{*}$ & - & - & - & - & - & - & $\mathrm{N}$ & $\mathrm{N}$ & - & - & - & - & - & - & - \\
\hline 8.6 & -16 & $B-* *$ & $13 \mathrm{~B}$ & - & - & - & 2 & $\mathrm{~N}$ & $\mathrm{~N}$ & $\mathrm{~N}$ & $\mathrm{~N}$ & $\mathrm{~N}$ & $\mathrm{~N}$ & $\mathrm{~N}$ & $\mathrm{~N}$ \\
\hline 8.7 & -1 & -*** & 13 & 14 & 14 & - & 4 & $\mathrm{~N}$ & $\mathrm{~N}$ & $\mathrm{~N}$ & $\mathrm{~N}$ & $\mathrm{~N}$ & $\mathrm{~N}$ & $\mathrm{~N}$ & $\mathrm{~N}$ \\
\hline $9.1^{*}$ & - & - & - & 12 & 10 & - & $\mathrm{N}$ & $\mathrm{N}$ & - & 6 & 6. & - & 14 & 16 & 6 \\
\hline 9.3 & & ;** & 13 & 14 & 15 & Buds & 4 & $\mathrm{~N}$ & $\mathrm{~N}$ & $\mathrm{~N}$ & $\mathrm{~N}$ & $\mathrm{~N}$ & $\mathrm{~N}$ & $\mathrm{~N}$ & $\mathrm{~N}$ \\
\hline $10.1^{*}$ & $\mathrm{X}$ & 18 & 14 & 13 & 13 & - & $\mathrm{N}$ & $\mathrm{N}$ & 5 & 6 & 6 & 2 & 14 & 19 & 6 \\
\hline 10.4 & XI & 17 & 12 & 15 & 15 & Buds & 4 & $\mathrm{~N}$ & $\mathrm{~N}$ & $\mathrm{~N}$ & $\mathrm{~N}$ & $\mathrm{~N}$ & $\mathrm{~N}$ & $\mathrm{~N}$ & $\mathrm{~N}$ \\
\hline 10.4 & XI & 15 & 11 & 14 & 14 & Buds & 4 & $\mathrm{~N}$ & $\mathrm{~N}$ & $\mathrm{~N}$ & $\mathrm{~N}$ & $\mathrm{~N}$ & $\mathrm{~N}$ & $\mathrm{~N}$ & $\mathrm{~N}$ \\
\hline 10.7 & $\mathrm{XI}$ & 17 & 12 & 15 & 15 & Buds & 4 & $\mathrm{~N}$ & $\mathrm{~N}$ & $\mathrm{~N}$ & $\mathrm{~N}$ & $\mathrm{~N}$ & $\mathrm{~N}$ & $\mathrm{~N}$ & $\mathrm{~N}$ \\
\hline $10.9^{*}$ & $\mathrm{XI}$ & 17 & 14 & 15 & 15 & I,3 & $\mathrm{N}$ & $\mathrm{N}$ & 7 & 6 & 6 & 6 & 15 & 21 & 6 \\
\hline 11.5 & $\mathrm{X}$ & 16 & 12 & 14 & 15 & $\mathrm{I}, 5$ & 4 & $\mathrm{~N}$ & $\mathrm{~N}$ & $\mathrm{~N}$ & $\mathrm{~N}$ & $\mathrm{~N}$ & $\mathrm{~N}$ & $\mathrm{~N}$ & $\mathrm{~N}$ \\
\hline $12.2^{*}$ & $\mathrm{XI}$ & 17 & 14 & 16 & 16 & I, 5 & $\mathrm{~N}$ & $\mathrm{~N}$ & 9 & 6 & 6 & 5 & 15 & 21 & 6 \\
\hline 13.8 & $\mathrm{XI}$ & 17 & 12 & 15 & 15 & $\mathbf{I}, 5$ & 4 & $\mathrm{~N}$ & $\mathrm{~N}$ & $\mathrm{~N}$ & $\mathrm{~N}$ & $\mathrm{~N}$ & $\mathrm{~N}$ & $\mathrm{~N}$ & $\mathrm{~N}$ \\
\hline $13.8^{*}$ & $\mathrm{XI}$ & 17 & 13 & $\mathrm{~N}$ & 15 & I,5 & $\mathrm{N}$ & $\mathrm{N}$ & 9 & 6 & 6 & 9 & 15 & 21 & 6 \\
\hline 14.7 & XI & 15 & 13 & 15 & 15 & $\mathrm{I}, 5$ & 4 & $\mathrm{~N}$ & $\mathrm{~N}$ & $\mathrm{~N}$ & $\mathrm{~N}$ & $\mathrm{~N}$ & $\mathrm{~N}$ & $\mathrm{~N}$ & $\mathrm{~N}$ \\
\hline 21.6 & $\mathrm{X}$ & 16 & 13 & 15 & 15 & $\mathrm{I}, 5$ & 4 & $\mathrm{~N}$ & $\mathrm{~N}$ & $\mathrm{~N}$ & $\mathrm{~N}$ & $\mathrm{~N}$ & $\mathrm{~N}$ & $\mathrm{~N}$ & $\mathrm{~N}$ \\
\hline
\end{tabular}

Table 42.-Measurements $(\mathrm{mm})$ of young of Scorpaenichthys marmoratus. (Specimens between dashed lines are undergoing notochord flexion.)

\begin{tabular}{|c|c|c|c|c|c|c|c|c|}
\hline $\begin{array}{l}\text { Body } \\
\text { length }\end{array}$ & $\begin{array}{l}\text { Head } \\
\text { length }\end{array}$ & $\begin{array}{l}\text { Snout } \\
\text { length }\end{array}$ & $\begin{array}{c}\text { Eye } \\
\text { diameter }\end{array}$ & $\begin{array}{c}\text { Snout to } \\
\text { anus length }\end{array}$ & $\begin{array}{c}\text { Body depth } \\
\text { at pectoral } \\
\text { fin base }\end{array}$ & $\begin{array}{r}\text { Pectoral } \\
\text { fin length }\end{array}$ & $\begin{array}{l}\text { 2d preoper- } \\
\text { cular } \\
\text { spine length }\end{array}$ & $\begin{array}{c}\text { Parietal } \\
\text { spine length }\end{array}$ \\
\hline 5.3 & 1.1 & 0.27 & 0.44 & 2.8 & 0.90 & 0.44 & - & - \\
\hline 5.4 & 1.2 & 0.27 & 0.56 & 2.9 & 0.98 & 0.40 & - & - \\
\hline 5.8 & 1.3 & 0.26 & 0.56 & 3.1 & 0.98 & 0.43 & - & - \\
\hline 6.1 & 1.4 & 0.30 & 0.56 & 3.1 & 1.1 & 0.48 & - & - \\
\hline 6.3 & 1.3 & 0.36 & 0.56 & 3.1 & 1.2 & 0.46 & - & - \\
\hline \multicolumn{9}{|c|}{ 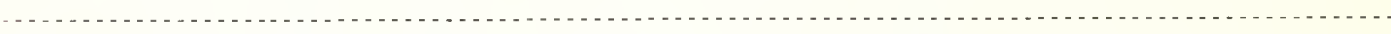 } \\
\hline 7.5 & 1.6 & 0.27 & 0.66 & 3.7 & 1.2 & 0.82 & - & - \\
\hline 8.1 & 1.9 & 0.31 & 0.82 & 4.6 & 1.9 & 0.55 & - & - \\
\hline 8.1 & 2.5 & 0.39 & 1.05 & 4.6 & 2.1 & 0.82 & 0.32 & - \\
\hline 8.6 & 1.9 & 0.35 & 0.68 & 4.2 & 1.6 & 0.70 & - & - \\
\hline 8.7 & 2.2 & 0.39 & 0.98 & 5.2 & 2.4 & 0.96 & 0.42 & - \\
\hline \multicolumn{9}{|c|}{ 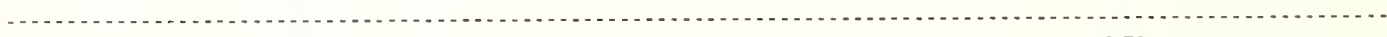 } \\
\hline 9.3 & 3.1 & 0.40 & 1.4 & 5.8 & 3.2 & 1.6 & 0.70 & - \\
\hline 10.4 & 3.8 & 0.72 & 2.2 & 6.2 & 3.3 & 1.8 & 0.90 & - \\
\hline 10.4 & 3.1 & 0.48 & 1.4 & 5.9 & 3.3 & 1.8 & 0.78 & - \\
\hline 10.7 & 3.4 & 0.48 & 1.7 & 6.5 & 3.8 & 2.0 & 0.78 & - \\
\hline 11.5 & 3.8 & 0.40 & 1.8 & 7.4 & 3.8 & 2.2 & 1.01 & Bump \\
\hline 13.8 & 5.4 & 0.96 & 2.2 & 8.9 & 4.6 & 3.0 & 1.24 & Bump \\
\hline 14.7 & 5.4 & 0.88 & 2.5 & 9.7 & 5.2 & 3.4 & 1.36 & $\ldots$ \\
\hline 21.6 & 8.8 & 1.92 & 2.7 & 15.5 & 8.2 & 6.2 & 1.44 & - \\
\hline
\end{tabular}


They become much deeper bodied with development with a body depth of $32-35 \%$ SL in postflexion stages. Snout to anus length is relatively long, increasing from $49-53 \%$ SL in preflexion larvae to $57-66 \%$ SL in postflexion larvae. The snout develops a rounded appearance, never pointed as in Radulinus sp. An unpigmented preanal finfold remains evident up to $\sim 13-14 \mathrm{~mm}$. The presence of such a preanal finfold has been reported for relatively few cottid genera (see Discussion under Rhamphocottus richardsoni).

Discussion. Scorpaenichthys is a monotypic genus. The larvae are rather distinctive and one of the most heavily pigmented forms of northeast Pacific cottid species. Small larvae appear somewhat similar to Radulinus spp. but have lateral pigment extending further toward the tail tip, no ventral midline melanophores posterior to the lateral pigment and usually no distinct line of melanophores along the lateral midline. Occasionally newly hatched larvae will have very few melanophores on the lateral body surface causing them to resemble small Hemilepidotus spinosus. However, their gut is longer and the dorsal and ventral midline pigment does not extend as far onto the tail tip as in $H$. spinosus.

Larvae of $S$. marmoratus appear to be strongly associated with the neuston. O'Connell (1953) reported dip net collections contained specimens 7.4-29 $\mathrm{mm}$ long, and we have taken specimens $4.0-35 \mathrm{~mm}$ in neuston tows off Oregon. One 10-min neuston tow taken $9 \mathrm{~km}$ off Newport, Oreg., in March contained 829 larvae, mostly 4-5 $\mathrm{mm}$ long and recently hatched. Richardson and Pearcy (1977) reported them to be a coastal form, as the larvae were only taken within $28 \mathrm{~km}$ of the coast in oblique plankton tows. However, we have since collected them in the neuston as far as $65 \mathrm{~km}$ offshore, well beyond the continental shelf-slope break.

\section{Cottoid Type A}

\section{(Figure 32; Tables 43, 44)}

Literature. No published descriptions of this form exist although illustrations were given by Richardson and Bond ${ }^{9}$ as "Globby Type A." These larvae were called

\footnotetext{
${ }^{9}$ Richardson, S. L., and C. E. Bond. 1978. Two unusual cottoid fishes from the northeast Pacific. Unpubl. manuscr., 6 p. Gulf Coast Research Laboratory, Ocean Springs, MS 39564, or Department of Fisheries and Wildlife, Oregon State University, Corvallis, OR 97331.
}

Psychrolutes-like sp. 1 by Richardson (footnote 4) and Richardson and Pearcy (1977).

Distinguishing Features. Three larval specimens (9.8, $12.8,13.4 \mathrm{~mm}$ ) of this unusual looking form have been collected off Oregon. The smallest specimen is undergoing notochord flexion and the two larger specimens are postflexion larvae. The largest larva, which was stained, has the full complement of dorsal, anal, pectoral, and pelvic fin rays but secondary caudal rays are still developing and the vertebral centra are not completely ossified, thus transformation occurs at a larger size.

The larvae are pigmented over the entire body except at the tail tip. The basal portion of the pectoral fin is pigmented, but its distal portion and the dorsal and anal finfolds are unpigmented.

No spines are apparent in the head region. The belly is covered with small, thumb-tack prickles which extend dorsolaterally in lesser numbers and a few are on the tail region in the larger specimens.

These larvae are globose in shape, unlike any other known cottid larvae. The outer skin is loose. They are deep bodied with depth at the pectoral fin base 42 and $56 \% \mathrm{SL}$ in the two specimens illustrated. Snout to anus distance is also great, 58 and $79 \% \mathrm{SL}$, respectively. The pelvic fins appear to be inserted in pockets in the skin with only the tips exposed in all three larvae. This condition may be variable as reported in adults in a Southern Hemisphere cottoid genus Neophrynichthys (Nelson 197 7) and as observed in larvae of a Bering Sea cottoid form (unpubl. data) referred to as Malacocottus zonurus Type 1 by Richardson and Bond (footnote 9). The first dorsal fin appears to be embedded in the skin and the second dorsal and anal fins are partially skin covered.

Discussion. Meristics, particularly the high number of pectoral fin rays and the possession of seven branchiostegal rays, agree with only one species described from the area, Psychrolutes phrictus (Stein and Bond 1978). Young stages of $P$. phrictus $<50 \mathrm{~mm}$ also have prickles in the belly region similar to these larvae. Based on this information alone our Cottoid Type A larvae would appear to be $P$. phrictus. However, discovery of a single 26.4 $\mathrm{mm}$ juvenile (Richardson and Bond footnote 9) which also agrees with $P$. phrictus in meristics and possession of belly prickles has lead to uncertainty regarding its identity. This unidentified juvenile differs drastically in body form from a $35 \mathrm{~mm}$ P. phrictus, primarily in relative

Table 43.-Meristics from larvae of Cottoid Type A. (Specimen above dashed line is undergoing notochord flexion.)

$\left[^{*}=\right.$ Specimen stained with Alizarin Red $\mathrm{S} ;{ }^{* *}=$ Dorsal fin spines and rays not distinguishable; $\mathrm{D}=$ Damaged; $\mathrm{N}=\mathrm{Not}$ examined. $]$

\begin{tabular}{|c|c|c|c|c|c|c|c|c|c|c|c|c|c|c|c|}
\hline \multirow{4}{*}{$\begin{array}{l}\text { Body } \\
\text { length }\end{array}$} & \multirow{3}{*}{\multicolumn{2}{|c|}{ Dorsal fin }} & \multirow{4}{*}{$\begin{array}{c}\text { Anal } \\
\text { fin } \\
\text { rays }\end{array}$} & & & \multirow{4}{*}{$\begin{array}{l}\text { Pelvic } \\
\text { fin } \\
\text { spine } \\
\text { \& rays }\end{array}$} & \multirow{4}{*}{$\begin{array}{c}\text { Preoper- } \\
\text { cular } \\
\text { spines }\end{array}$} & \multirow{4}{*}{$\begin{array}{l}\text { Ventral } \\
\text { midline } \\
\text { melano- } \\
\text { phores }\end{array}$} & \multicolumn{4}{|c|}{ Caudal fin rays } & \multirow{2}{*}{\multicolumn{2}{|c|}{ Vertebrae }} & \multirow{4}{*}{$\begin{array}{c}\text { Branchi- } \\
\text { ostegal } \\
\text { rays }\end{array}$} \\
\hline & & & & \multirow{2}{*}{\multicolumn{2}{|c|}{$\begin{array}{l}\text { Pectoral } \\
\text { fin rays }\end{array}$}} & & & & \multicolumn{2}{|c|}{ Dorsal } & \multicolumn{2}{|c|}{ Ventral } & & & \\
\hline & & & & & & & & & Second- & Prin- & Prin- & Second- & \multirow{2}{*}{$\begin{array}{l}\text { Abdom- } \\
\text { inal }\end{array}$} & \multirow{2}{*}{$\begin{array}{c}\text { Cau- } \\
\text { dal }\end{array}$} & \\
\hline & Spines & Rays & & Left & Right & & & & ary & cipal & cipal & ary & & & \\
\hline 9.8 & & $* * *$ & 11 & 23 & 23 & - & - & - & $\mathrm{N}$ & $\mathrm{N}$ & $\mathrm{N}$ & $\mathrm{N}$ & $\mathrm{N}$ & $\mathrm{N}$ & $\mathrm{N}$ \\
\hline 12.8 & & *** & 11 & 24 & D & - & - & - & $\mathrm{N}$ & $\mathrm{N}$ & $\mathrm{N}$ & $\mathrm{N}$ & $\mathrm{N}$ & $\mathrm{N}$ & $\mathrm{N}$ \\
\hline $13.4^{*}$ & VIII & 20 & 14 & 26 & 26 & $\mathrm{I}, 3$ & - & - & - & 6 & 7 & 4 & 12 & 23 & 7 \\
\hline
\end{tabular}




\section{Cottoid Type A}
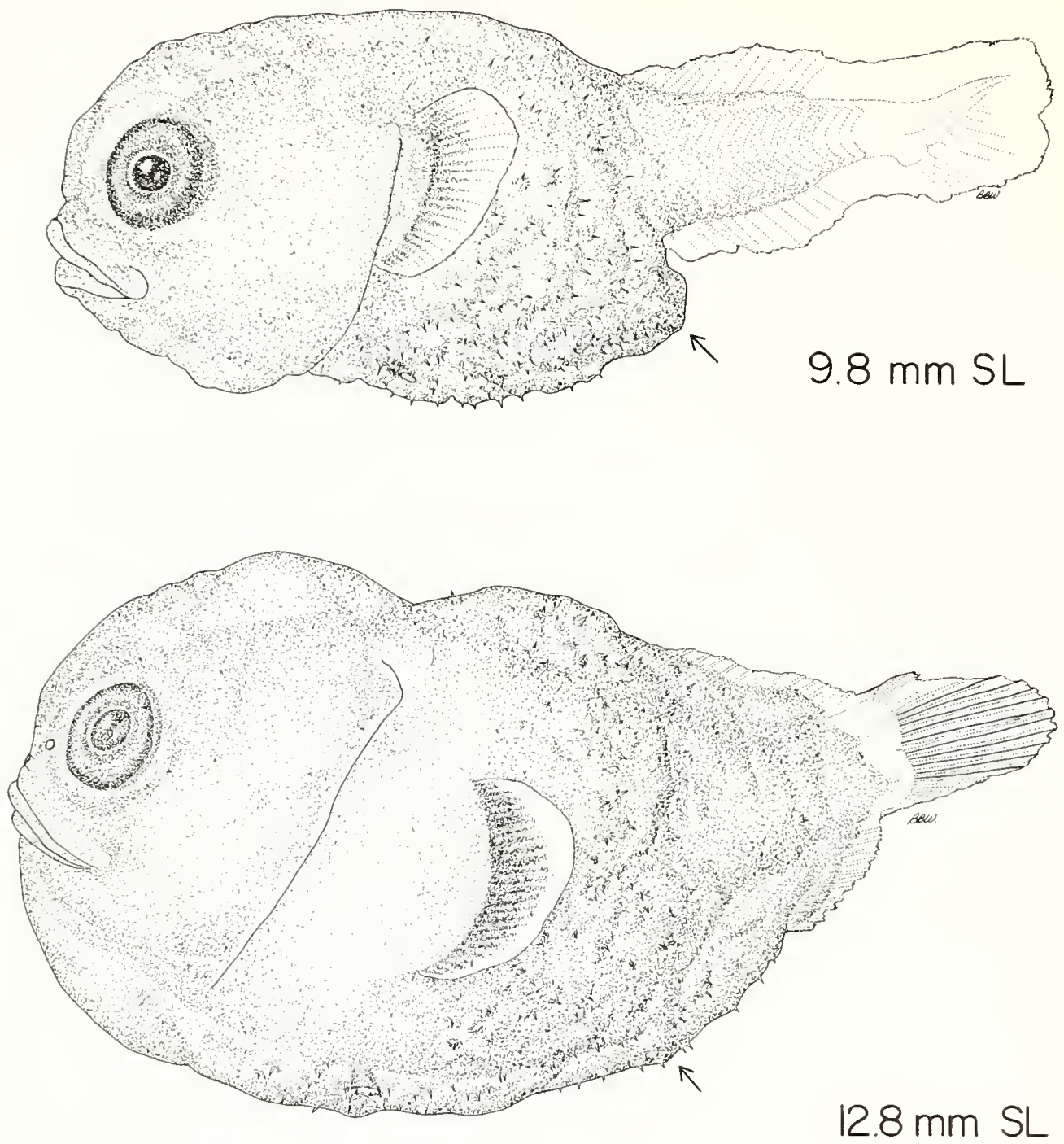

Figure 32.--Larvae of Cottoid Type A. Arrows indicate the position of the anus.

Table 44.-Measurements $(\mathrm{mm})$ of larvae of Cottoid Type A. (Specinen above dashed line is undergoing notochord flexion.)

\begin{tabular}{|c|c|c|c|c|c|c|c|c|}
\hline $\begin{array}{l}\text { Body } \\
\text { length }\end{array}$ & $\begin{array}{l}\text { Head } \\
\text { length }\end{array}$ & $\begin{array}{l}\text { Snout } \\
\text { length }\end{array}$ & $\begin{array}{c}\text { Eye } \\
\text { diameter }\end{array}$ & $\begin{array}{l}\text { Snout to } \\
\text { anus length }\end{array}$ & $\begin{array}{l}\text { Body depth } \\
\text { at pectoral } \\
\text { fin base }\end{array}$ & $\begin{array}{l}\text { Pectoral } \\
\text { fin length }\end{array}$ & $\begin{array}{l}2 \mathrm{~d} \text { preoper- } \\
\text { cular } \\
\text { spine length }\end{array}$ & $\begin{array}{c}\text { Parietal } \\
\text { spine length }\end{array}$ \\
\hline 9.8 & 3.6 & 0.66 & 1.2 & 5.7 & 4.1 & 1.7 & - & - \\
\hline 12.8 & 6.1 & 1.5 & 1.7 & 10.1 & 7.2 & 3.7 & - & - \\
\hline
\end{tabular}


body depth (51\% and $31 \% \mathrm{SL}$, respectively) and snout to anus length $(61 \%$ and $51 \% \mathrm{SL}$, respectively). The unidentified $26.4 \mathrm{~mm}$ juvenile agrees much more closely with our Cottoid Type A larvae than with the $35 \mathrm{~mm} P$. phrictus juvenile. It seems unlikely that a drastic change in body proportion would occur during the juvenile period between 26 and $35 \mathrm{~mm}$. And the $26.4 \mathrm{~mm}$ specimen does not appear to be distorted, based on radiographs. It also seems unlikely that two such unusual forms would exist in the northeast Pacific that agree so well in meristics and belly prickles. However, the identification of our Cottoid Type A larvae as $P$. phrictus cannot be positively made until additional material becomes available to provide a conclusive linkage between our larvae and identified juveniles.

If our Cottoid Type A larvae are found to be $P$. phrictus, then placement of this species in the genus $P s y$ chrolutes is obviously in error based on the extreme dissimilarity of these larvae and those of $P$. paradoxus described by Blackburn (1973) (10.3 mm SL) and Marliave (1975) $(10.5,13,14 \mathrm{~mm} \mathrm{TL})$, and its generic position should be reexamined. Alternatively, these larvae could represent a new species and possibly a new genus of cottoid fish from the northeast Pacific. The term "cottoid" has been used here because of the dissimilarity of these larvae to any known larvae in the Family Cottidae.

\section{NOTES ON OTHER NORTHEAST PACIFIC COTTID LARVAE}

Larvae are known for 14 additional species of northeast Pacific cottids not described in this paper (Table
45). Those in the genera Artedius, Clinocottus, and Hemilepidotus (including Melletes from the Bering Sea) were discussed under the descriptions of related species. Larvae of Oligocottus spp. were discussed under Cottidae Type 3. Comments on the larval characters in remaining genera, Blepsias, Dasycottus, Gilbertidia, ?Malacocottus, Myoxocephalus, Orthonopias, and Psychrolutes are included here for comparative purposes, based on the literature cited in Table 45 and personal observations of specimens not in the Oregon State University Larval Fish Reference Collection.

Larvae of Blepsias cirrhosus are one of the dark, heavily pigmented forms along with Radulinus spp., Rhamphocottus richardsoni, and Scorpaenichthys marmoratus. The entire body is covered with dense melanophores except for the tail tip, the ventral surface of the gut, and the cheek. The pectoral fins are unpigmented and no melanophores occur on the finfold as in $R$. richardsoni. They have no preanal finfold as in $R$. richardsoni and $S$. marmoratus. They apparently hatch at a relatively large size. The smallest larvae reported from plankton collections are $10 \mathrm{~mm}$ TL and just beginning to undergo notochord flexion. Thus, they are generally less developed than the above-mentioned dark cottid larvae at comparable sizes. The larvae appear more slender with respect to body length than $S$. marmoratus and $R$. richardsoni and relative snout to anus length is less than in $R$. richardsoni. They do not develop the pronounced preopercular spines seen in $S$. marmoratus. The largest specimen reported from plankton collections is $25.5 \mathrm{~mm} \mathrm{TL}$ and is apparently transformed, or nearly so.

Table 45.-Additional northeast Pacific cottid species for which larvae and young are known.

\begin{tabular}{|c|c|c|}
\hline Species & Reference & Size illustrated \\
\hline Artedius lateralis & $\begin{array}{l}\text { Budd } 1940 \\
\text { Marliave } 1975\end{array}$ & $\begin{array}{l}4.1 \mathrm{~mm} \mathrm{SL} \\
4,8,11,14 \mathrm{~mm} \text { TL }\end{array}$ \\
\hline Blepsias cirrhosus & $\begin{array}{l}\text { Blackburn } 1973 \\
\text { Marliave } 1975\end{array}$ & $\begin{array}{l}12.2 \mathrm{~mm} \mathrm{SL} \\
10,14,19,25.5 \mathrm{~mm} \text { TL }\end{array}$ \\
\hline Clinocottus analis & $\begin{array}{l}\text { Eigenmann } 1892 \\
\text { Budd } 1940\end{array}$ & $\begin{array}{l}\sim 4 \mathrm{~mm} \\
\sim 4 \mathrm{~mm}\end{array}$ \\
\hline Clinocottus recalvus & Morris 1951 & $\begin{array}{l}4.6,5.0,7.6,8.3,9.9,10.8,18.0 \\
\quad 24.3 \mathrm{~mm} \text { TL }\end{array}$ \\
\hline Dasycottus setiger & Blackburn 1973 & $7.4 \mathrm{~mm} \mathrm{SL}$ \\
\hline Gilbertidia sigalutes & $\begin{array}{l}\text { Blackburn } 1973 \\
\text { Marliave } 1975\end{array}$ & $\begin{array}{l}7.3,9.5 \mathrm{~mm} \mathrm{SL} \\
7,13,15,25,34 \mathrm{~mm} \text { TL }\end{array}$ \\
\hline Hemilepidotus jordani & $\begin{array}{l}\text { Gorbunova } 1964 \\
\text { Peden } 1964\end{array}$ & $\begin{array}{l}6.4,10.7,13.0 \mathrm{~mm} \\
\sim 20 \mathrm{~mm}\end{array}$ \\
\hline Hemilepidotus zapus & Peden 1964 & $\sim 20 \mathrm{~mm}$ \\
\hline $\begin{array}{l}\text { ?Malacocottus zonurus } \\
\text { - Type } 1\end{array}$ & $\begin{array}{l}\text { Richardson and Bond } 1978^{1} \\
\text { Richardson (unpubl. data) }\end{array}$ & $\begin{array}{l}7.0,9.8,14.2,24.0 \mathrm{~mm} \mathrm{SL} \\
6.6,7.0,8.8,9.8,10.4,14.2,24.0 \\
\quad \mathrm{~mm} \mathrm{SL}\end{array}$ \\
\hline $\begin{array}{l}\text { Myoxocephalus polya- } \\
\text { canthocephalus }\end{array}$ & Blackburn 1973 & $7.7,10.7 \mathrm{~mm} \mathrm{SL}$ \\
\hline $\begin{array}{l}\text { Oligocottus maculosus } \\
\text { Oligocottus snyderi }\end{array}$ & $\begin{array}{l}\text { Stein } 1972 \\
\text { Stein } 1973 \\
\text { Stein } 1972\end{array}$ & $\begin{array}{l}4.6-5.2,6.0,6.6,9.2 \mathrm{~mm} \mathrm{TL} \\
4.6-5.2,6.0,6.6,9.2,12.2 \mathrm{~mm} \mathrm{TL} \\
4.5-4.75,5.5 \mathrm{~mm} \mathrm{TL}\end{array}$ \\
\hline Orthonopias triacis & Bolin 1941 & $\sim 3-4 \mathrm{~mm} \mathrm{SL}$ \\
\hline Psychrolutes paradoxus & $\begin{array}{l}\text { Blackburn } 1973 \\
\text { Marliave } 1975\end{array}$ & $\begin{array}{l}10.3 \mathrm{~mm} \mathrm{SL} \\
10.5,13,14,13 \mathrm{~mm} \mathrm{TL}\end{array}$ \\
\hline
\end{tabular}

${ }^{1}$ See text footnote 9 
Larvae of Dasycottus setiger are characterized by a relative lack of pigment on the body except on the head and over the relatively short gut. Melanophores in these two regions are low in numbers but are large in appearance, thus covering most of the head and abdominal cavity. Pigment is absent from the postanal ventral midline. Pigment is present on the underside of the pectoral fin and later is added to the blade and outer side of the fin. The general pigment pattern, except for the pigmented pectorals, resembles our Triglops sp. but the number of myomeres is much lower for D. setiger, $\sim 34$ 35. The smallest larvae reported are $7.4 \mathrm{~mm}$ and presumed to be recently hatched. Fin rays are formed by 12 $\mathrm{mm}$ and the pigment pattern remains unchanged at least until $19 \mathrm{~mm}$. A $24 \mathrm{~mm}$ SL specimen observed by us has begun to acquire juvenile pigmentation.

Small larvae of Gilbertidia sigalutes and Psychrolutes paradoxus are similar to each other. Both hatch at $\sim 6-7$ $\mathrm{mm}$. The smallest larvae resemble those of liparids in general shape. Both have moderate melanistic pigment over the head, nape, gut, and on the pectoral fins. Postanal ventral midline melanophores are absent. On both, pigment is added to the lateral body surface above the abdominal cavity and posterior to it, with relatively more pigment present in $P$. paradoxus than $G$. sigalutes of similar size particularly in larger specimens. Both develop the appearance of having loose skin. The number of pectoral fin rays separate the two with $\geq 19$ for $P$. paradoxus and $\leq 18$ for $G$. sigalutes. These are usually countable on all but the smallest larvae. Additional definitive differences between the smallest larvae of these two species, based on plankton preserved material, remain to be described. Blackburn (1973) indicated differences exist in the shape of melanophores on the pectoral fin and head, but we have not found this to be consistent and reliable. Marliave (1975) stated that freshly preserved larvae of $P$. paradoxus have more melanin in the pectoral fins which obscures their orange color while the pectoral fins of $G$. sigalutes appear bright orange. Thus there may be real differences in the melanistic pigment patterns on the pectoral fins of small larvae, but the limits of variation of those patterns remain to be defined. Pectoral fin pigment differences are apparent in larger preserved specimens with those of $G$. sigalutes being much darker and having unpigmented circles near the margin. Marliave also stated that $P$. paradoxus larvae develop a notch dorsally in the caudal finfold during fin ray formation whereas $G$. sigalutes larvae do not. This was not obvious on all specimens we have examined. Marliave observed that $P$. paradoxus settles from the plankton $\sim 13-14 \mathrm{~mm}$ TL while $G$. sigalutes remains pelagic until $>20 \mathrm{~mm}$ TL. Larvae of an additional form from the Gulf of Alaska and Bering Sea, tentatively called Malacocottus zonurus - Type 1 by Richardson and Bond (footnote 9), are also very similar in appearance to larvae of $G$. sigalutes and $P$. paradoxus. Small larvae of all three are nearly identical but larvae of $M$. zonurus - Type 1 develop 4 preopercular spines with an anteriorly directed accessory spine at the base of the second spine. This secondary spine is visible on larvae by $\sim 7 \mathrm{~mm}$ upon close examination. Pectoral fin ray counts, $\sim 20-22$, will further separate it from $G$. sigalutes. Often the pelvic fins of $M$. zonurus - Type 1 appear to be withdrawn into pockets in the skin, although this condition is variable. This form has very loose skin and remains pelagic at least until $\sim 24 \mathrm{~mm}$. Positive identification of these larvae as $M$. zonurus awaits resolution of apparent taxonomic problems in the genus Malacocottus (Howe and Richardson footnote 3; Richardson and Bond footnote 9).

In larvae of Myoxocephalus polyacanthocephalus, which hatch $\sim 7 \mathrm{~mm}$, melanophores cover most of the anterior one-half to two-thirds of the body except the ventral surface of the abdomen. The posterior one-third of the body remains conspicuously unpigmented except for a series of small melanophores along the ventral midline which extends to near the tail tip. The pigment pattern is similar to other dark cottid larvae, e.g., Radulinus asprellus, Rhamphocottus richardsoni, Scorpaenichthys marmoratus, Blepsias cirrhosus, except that a greater proportion of the tail region remains unpigmented laterally and the unpigmented tail region also retains a series of ventral midline melanophores. The head develops prominent spines including at least 4 preopercular, a parietal, a nuchal, a postocular, and several in the posttemporal-supracleithral region.

Early larvae of Orthonopias triacis resemble those of Artedius spp. with which it is closely related (Howe and Richardson footnote 3 ). At hatching they have pigment over the gut and a series of $\sim 35$ postanal ventral midline melanophores. Soon after hatching pigment is added to the interorbital region and on the nape. Apparently no gut diverticula are present. Characters given in the literature are inadequate to distinguish them from Artedius harringtoni except for possibly a higher number of ventral midline melanophores.

\section{ACKNOWLEDGMENTS}

Examination of larval cottids from other areas of the northeast Pacific was helpful in working out identifications of our Oregon cottid larvae. We thank the following people with collections from particular areas: northern California-David W. Rice (Lawrence Livermore Laboratory); Washington and Puget Sound-Jean R. Dunn and Kenneth D. Waldron (Northwest and Alaska Fisheries Center, National Marine Fisheries Service, NOAA), Lawrence Moulton (University of Washington), James Blackburn (Alaska Department of Fish and Game formerly of University of Washington), Andrew Lamb (Pacific Environment Institute, Vancouver), British Columbia-W. E. Barraclough (Fisheries Research Board of Canada, Nanaimo) and Daniel J. Faber (Canadian Oceanographic Identification Center); Bering Sea and Gulf of Alaska-Pat Wagner and George Mueller (University of Alaska). Jean R. Dunn provided reared larvae of Hemilepidotus hemilepidotus. Kevin Howe, Oregon State University, provided transforming and juvenile cottids collected in Oregon tidepools and general information on tidepool collections. James Blackburn and Jeffrey B. Marliave, Vancouver Public Aquarium, pro- 
vided specimens of Gilbertidia sigalutes and Psychrolutes paradoxus for comparative examination. Many people helped in one way or another in working out larval cottid identification problems particularly E. H. Ahlstrom, NOAA, NMFS Southwest Fisheries Center; James Blackburn; Carl E. Bond, Oregon State University; Jean R. Dunn; Kevin Howe; Joanne L. Laroche, Oregon State University; Wayne L. Laroche, Oregon State University; Kenneth Waldron; and Sharon Roe, formerly of Oregon State University. We thank E. H. Ahlstrom and Carl E. Bond for reviewing the manuscript and offering helpful comments. Special thanks are extended to Jean R. Dunn whose efforts made this paper possible. This research was supported in part by NOAANMFS Contract No. 03-78-M02-120, 1 January 1978 to 30 September 1978.

\section{LITERATURE CITED}

AHLSTROM, E. H., J. L. BUTLER, and B. Y. SUMIDA.

1976. Pelagic stromateoid fishes (Pisces, Perciformes) of the eastern Pacific: Kinds, distributions, and early life histories and observations on five of these from the northwest Atlantic. Bull. Mar. Sci. 26:285-402.

BEARDSLEY, A. J., and C. E. BOND.

1970. Field guide to common marine and bay fishes of Oregon. Oreg. State Univ. Agric. Exp. Stn. Bull. 607, 27 p.

BLACKBURN, J. E.

1973. A survey of the abundance, distribution, and factors affecting distribution of ichthyoplankton in Skagit Bay. M.S. Thesis., Univ. Washington, Seattle, $136 \mathrm{p}$

BOLIN, R. L.

1941. Embryonic and early larval stages of the cottid fish Orthonopias triacis Starks and Mann. Stanford Ichthyol. Bull. 2:7382

1944. A review of the marine cottid fishes of California. Stanford Ichthyol. Bull. 3:1-135.

BREDER, C. M., Jr., and D. E. ROSEN.

1966. Modes of reproduction in fishes. Natural History Press, Garden City, N.Y., 941 p.

BUDD, P. L.

1940. Development of the eggs and early larvae of six California fishes. Calif. Dep. Fish Game, Fish. Bull. 56:1-50.

EHRENBAUM, E.

1905-1909. Eier und Larven von Fischen. In Nordisches Plankton; Zoologischer Teil Erster Band, p. 1-414. Kiel und Leipzig.

EIGENMANN, C. H.

1892. The fishes of San Diego, California. Proc. U.S. Natl. Mus. 15:123-178.

ELDRIDGE, M. B.

1970. Larval fish survey of Humboldt Bay. M.S. Thesis, Humboldt State Coll., Arcata, Calif., $52 \mathrm{p}$.

FEDOROV, V. V.

1973. A list of Bering Sea fish. [In Russ.] Proc. TINRO 87:42-71. [Engl. transl. by Transl. Bur., Multilingual Serv. Div., Dep. Sec. State Canada, Fish. Mar. Ser. Transl. Ser. No. 3271.]

FOLLETT, W. I.

1952. Annotated list of fishes obtained by the California Academy of Sciences during six cruises of the U.S.S. Mulberry, conducted by the United States Navy off central California in 1949 and 1950. Proc. Calif. Acad. Sci., Ser. 4, 27:399-432.

FUIMAN, L. A.

1976. Notes on the early development of the sea raven, Hemitripterus americanus. Fish. Bull., U.S. 74:467-470.

GORBUNOVA, N. N.

1964. Breeding and development of hemilipidotine sculpins (Cottidae, Pisces). In T. S. Rass (editor), Fishes of the Pacific and In- dian Oceans. Biology and distribution, p. 249-266. Israel Program Sci. Transl. No. 1411.

HART, J. L.

1973. Pacific fishes of Canada. Fish. Res. Board Can. Bull. 180, $740 \mathrm{p}$.

HATTORI, S.

1964. Studies on fish larvae in the Kuroshio and adjacent waters. [In Jpn., Engl. synop.] Bull. Tokai Reg. Fish. Res. Lab. $40,158 \mathrm{p}$.

JONES, A. C.

1962. The biology of the euryhaline fish Leptocottus armatus armatus Girard (Cottidae). Univ. Calif. Publ. Zool. 67:321-368.

KHAN, N. Y.

1972. Comparative morphology and ecology of the pelagic larvae of nine Cottidae (Pisces) of the northwest Atlantic and St. Lawrence drainage. Ph.D. Thesis., Univ. Ottawa, Ottawa, 234 p.

KOEFOED, E

1907. Croisiére oceanographique dans la mer du Gronland en 1905. Charles Bulens, Brussels, p. 485-500. (Cited by Khan 1972; not seen by authors.)

KYUSHIN, K

1970. Embryonic development and larvae of Gymnocanthus herzensteini Jordan and Starks. Jpn. J. Ichthyol. 17:74-79.

LUND, W. A., Jr., and B. C. MARCY, Jr.

1975. Early development of the grubby, Myoxocephalus aenaeus (Mitchill). Biol. Bull. (Woods Hole) 149:373-383.

MARLIAVE, J. B.

1975. The behavioral transformation from the planktonic larval stage of some marine fishes reared in the laboratory. Ph.D. Thesis, Univ. British Columbia, Vancouver, $231 \mathrm{p}$.

MILLER, D. J., and R. N. LEA.

1972. Guide to the coastal marine fishes of California. Calif. Dep. Fish Game, Fish. Bull. 157, 235 p.

MISITANO, D. A

1978. Description of laboratory-reared larvae of the buffalo sculpin, Enophrys bison Girard (Pisces:Cottidae). Copeia 1978:635642 .

MORRIS, R. W

1951. Early development of the cottid fish, Clinocottus recaluus (Greeley). Calif. Fish Game 37:281-300.

NELSON, J. S.

1977. Fishes of the southern hemisphere genus Neophrynichthys (Scorpaeniformes : Cottoidei), with descriptions of two new species from New Zealand and Macquarie Island. J. R. Soc. N.Z. 7:485-511.

O'CONNELL, C. P.

1953. The life history of the cabezon Scorpaenichthys marmoratus (Ayres). Calif. Dep. Fish Game, Fish. Bull. 93:1-76.

OKIYAMA, M., and H. SANDO.

1976. Early life history of the sea raven, Hemitripterus villosus, (Hemitripterinae, Cottidae) in the Japan Sea. [In Jpn., Engl. abstr.] Bull. Jpn. Sea Reg. Fish. Res. Lab 27:1-10.

PEDEN, A. E.

1964. A systematic revision of the Hemilepidotinae, a subfamily of the cottid fishes. M.S. Thesis, Univ. British Columbia, Vancouver, $162 \mathrm{p}$

QUAST, J. C., and E. L. HALL.

1972. List of fishes of Alaska and adjacent waters with a guide to some of their literature. U.S. Dep. Commer., NOAA Tech. Rep. NMFS SSRF-658, $47 \mathrm{p}$.

RASS, T. S

1949. Fish eggs and larvae of the Barents Sea. Proc. All Union Res. Inst. Mar. Fish. Oceanogr. (VNIRO) 17:9-65.

RICHARDSON, S. L.

In press. Current knowledge of northeast Pacific sculpin larva (Family Cottidae) with notes on relationships within the family. ICES/Early Life History Symposium, Cons. Int. Expl. Mer., Rapp. Proc.-Verb. Reunions.

RICHARDSON, S. L., and W. A. LAROCHE.

1979. Development and occurrence of larvae and juveniles of the rockfishes Sebastes crameri, Sebastes pinniger, and Sebastes helvomaculatus (Family Scorpaenidae) off Oregon. Fish. Bull., U.S. 77:1-46. 
RICHARDSON, S. L., and W. G. PEARCY.

1977. Coastal and oceanic fish larvae in an area of upwelling off Yaquina Bay, Oregon. Fish. Bull., U.S. 75:125-145.

RUSSELL, F. S.

1976. The eggs and planktonic stages of British marine fishes. Acad. Press, N.Y., 524 p.

SANDERCOCK, F. K., and N. J. WILIMOVSKY.

1968. Revision of the cottid genus Enophrys. Copeia 1968:832853.

SCOTT, W. B., and E. J. CROSSMAN.

1973. Freshwater fishes of Canada. Bull. Fish. Res. Board Can., Bull. 184, 966 p.

STEIN, D. L., and C. E. BOND.

1978. A new deep-sea fish from the eastern north Pacific, Psychrolutes phrictus (Pisces: Cottidae [Psychrolutinae]). Los Ang. Cty. Mus., Contrib. Sci. 296, 9 p.
STEIN, R.

1972. Identification of some Pacific cottids. M.S. Thesis, Humboldt State Coll., Arcata, Calif., 41 p.

1973. Description of laboratory-reared larvae of Oligocottus maculosus Girard (Pisces:Cottidae). Copeia 1973:373-377.

TAYLOR, W. R.

1967. An enzyme method of clearing and staining small vertebrates. Proc. U.S. Natl. Mus. 122(3596):1-17.

WARFEL, H. E., and D. MERRIMAN

1944. The spawning habits, eggs and larvae of the sea raven, Hemitripterus americanus, in southern New England. Copeia 1944:197-205.

WHITE, W. A.

1977. Taxonomic composition, abundance, distribution and seasonality of fish eggs and larvae in Newport Bay, California. M.S. Thesis, Calif. State Univ., Fullerton, 107 p. 


\section{NOAA TECHNICAL REPORTS \\ NMFS CIRCULAR AND SPECIAL SCIENTIFIC REPORT-FISHERIES GUIDELINES FOR CONTRIBUTORS}

\section{CONTENTS OF MANUSCRIPT}

First page. Give the title (as concise as possible) of the paper and the author's name, and fo note the author's affiliation, mailing address, and ZIP code.

Contents. Contains the text headings and abbreviated figure legends and table headings. Dots should follow each entry and page numbers should be omitted.

Abstract. Not to exceed one double-spaced page. Footnotes and literature citations do not belong in the abstract.

Text. See also Form of the Manuscript below. Follow the U.S. Government Printing Office Style Manual, 1973 edition. Fish names, follow the American Fisheries Society Special Publication No. 6, A List of Common and Scientific Names of Fishes from the United States and Canada, third edition, 1970. Use short, brief, informative headings in place of "Materials and Methods."

Text footnotes. Type on a separate sheet from the text. For unpublished or some processed material, give author, year, title of manuscript, number of pages, and where it is filed-agency and its location.

Personal communications. Cite name in text and footnote. Cite in footnote: John J. Jones, Fishery Biologist, Scripps Institution of Oceanography, La Jolla, CA 92037, pers. commun. 21 May 1977.

Figures. Should be self-explanatory, not requiring reference to the text. All figures should be cited consecutively in the text and their placement indicated in the left-hand margin of the manuscript. Photographs and line drawings should be of "professional" quality-clear and balanced, and can be reduced to $6 \frac{1}{2}$ inches (40 picas) for page width or to $31 / 8$ inches (19 picas) for single-column width, but no more than 9 inches ( 54 picas) high. Photos should be printed on glossy paper-sharply focussed, good contrast. J abel each figure. List, and typed double spaced, each figure legend. DO NOT SEND original figures to the Scientific Editor; NMFS Scientific Publications Office will request these if they are needed.

Tables. Each table should start on a separate page and should be self-explanatory, not requiring reference to the text. Headings should be short but amply descriptive. Use only horizontal rules. Number table footnotes consecutively across the page from left to right in Arabic numerals; and to avoid confusion with powers, plice them to the left of the numerals. If the original $\mathrm{t}^{-}$bles are typed in our format and are clean and legible, these tables will be reproduced as they are. In the text all tables should be cited consecutively and their placement indicated in the left-hand margin of the manuscript.

Acknowledgments. Place at the end of text. Give credit only to those who gave exceptional contributions and not to those whose contributions are part of their normal duties.
Literature cited. In text as: Smith and Jones (1977) or (Smith and Jones 1977); if more than one author, list according to years (e.g., Smith 1936; Jones et al. 1975; Doe 1977). All papers referred to in the text should be listed alphabetically by the senior author's surname under the heading "Literature Cited"; only the author's surname and initials are required in the author line. The author is responsible for the accuracy of the literature citations. Abbreviations of names of pericdicals and serials should conform to Biological A bstracts List of Serials with Title Abbreviations. Format, see recent SSRF or Circular.

Abbreviations and symbols. Common ones, such as $\mathrm{mm}, \mathrm{m}$, g, $\mathrm{ml}, \mathrm{mg},{ }^{\circ} \mathrm{C}$ (for Celsius), $\%, \%$, etc., should be used. Abbreviate units of measures only when used with numerals; periods are rarely used in these abbreviations. But periods are used in et al., vs., e.g., i.e., Wash. (WA is used only with ZIP code), etc. Abbreviations are acceptable in tables and figures where there is lack of space.

Measurements. Should be given in netr: $\mathrm{c}$ units. Other equivalent units may be given in parentheses.

\section{FORM OF THE MANUSCRIPT}

Original of the manuscript should be typed double-spaced on white bond paper. Triple space above heading: Send good duplicated copies of manuscript rath 2 r than carbon copies. The sequence of the material should be:

\author{
FIRST PAGE \\ CONTENTS \\ ABSTRACT \\ TEXT \\ LITERATURE CITED \\ TEXT FOOTNOTES \\ APPENDIX \\ TABLES (each table should be numbered with an Arabic \\ numeral and heading provided) \\ LIST OF FIGURE LEGENDS (Entire figure legends, includ- \\ ing "Figure" before each number) \\ FIGURES
}

\section{ADDITIONAL INFORMATION}

Send ribbon copy and two du, licated copies of the manuscript to:

\author{
Dr. Jay C. Quast, Scientific Editor \\ Northwest and Alaska Fisheries Center \\ Auke Bay Laboratory \\ National Marine Fisheries Service, NOAA \\ P.O. Box 155 \\ Auke Bay, AK 99821
}

Copies. Fifty copies will be supplied to the senior author and 100 to his organization free of charge. 


\section{NOAA SCIENTIFIC AND TECHNICAL PUBLICATIONS}

NOAA, the National Oceanic and Atmospheric Administration, was established as part of the Department of Commerce on October 3, 1970. The mission responsibilities of NOAA are to monitor and predict the state of the solid Earth, the oceans and their living resources, the atmosphere, and the space environment of the Earth, and to assess the socioeconomic impact of natural and technological changes in the environment.

The six Major Line Components of NOAA regularly produce various types of scientific and technical information in the following kinds of publications:

PROFESSIONA: PAPERS-Important definitive research results, major techniques, and special investigations.

TECHNICAL REPORTS-Journal quality with extensive details, mathematical developments, or data listings.

TECHNICAL MEMORANDUMS-Reports of preliminary, partial, or negative research or technology results, interim instructions, and the like.

CONTRACT AND GRANT REPORTS-Reports prepared by contractors or grantees under NOAA sponsorship.
TECHNICAL SERVICE PUBLICATIONSThese are publications containing data, observations, instructions, etc. A partial listing: Data serials; Prediction and outlook periodicals; Technical manuals, training papers. planning reports, and information serials; and Miscellaneous technical publications.

ATLAS-Analysed data generally presented in the form of maps showing distribution of rainfall, chemical and physical conditions of oceans and atmosphere, distribution of fishes and marine mammals, ionospheric conditions, etc.

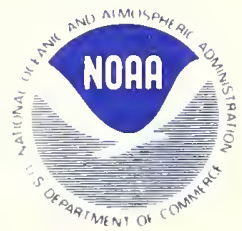

Information on avallabllity of NOAA publlcatlons can be obtained from:

ENVIRONMENTAL SCIENCE INFORMATION CENTER ENVIRONMENTAL DATA AND INFORMATION SERVICE NATIONAL OCEANIC AND ATMOSPHERIC ADMINISTRATION U.S. DEPARTMENT OF COMMERCE 